\title{
A type catalogue of the reed frogs (Amphibia, Anura, Hyperoliidae) in the collection of the Museum für Naturkunde Berlin (ZMB) with comments on historical collectors and expeditions
}

\author{
Frank Tillack ${ }^{1}$, Ronald de Ruiter ${ }^{2}$, Mark-Oliver Rödel ${ }^{1}$ \\ 1 Museum für Naturkunde Berlin, Leibniz-Institute for Evolution and Biodiversity Science, Invalidenstraße 43, 10115 Berlin, Germany \\ 2 Nederlands Openluchtmuseum, Hoeferlaan 4, 6816 SG Arnhem, The Netherlands \\ http://zoobank.org/DC2EBA62-93A1-4193-8ADC-2A79F7D658B9 \\ Corresponding author: Mark-Oliver Rödel (mo.roedel@mfn.berlin)
}

Academic editor: Johannes Penner • Received 28 April 2021 • Accepted 17 June 2021 • Published 10 August 2021

\begin{abstract}
We present a commented catalogue of the type specimens of the Afro-Malagasy frog family Hyperoliidae at the herpetological collection of the Museum für Naturkunde Berlin (ZMB). In current publications and databases, many names based on ZMB primary types are listed as synonyms of other species, the types often declared as lost. Consequently, the respective names are often no longer considered in current taxonomic work. We traced 146 nominal taxa of the family Hyperoliidae in the ZMB collection of which currently 130 are presented by primary types ( 88 holotypes, 10 lectotypes and 32 taxa based on syntype series); 50 of these taxa are currently considered as valid. Primary types of nine taxa could not be located during our inventory of the collection holdings. Seven taxa are exclusively represented by secondary types (paratypes). Many of these types comprise taxa where types have been thought to be lost. As a further service to the community, we provide important details about collectors and their travel routes, as well as respective documents stored in the collection of the Department of Historical Research at ZMB. This should make it easier to potentially compare the ZMB types in future taxonomic revisions.
\end{abstract}

\section{Key Words}

Africa, colonies, historical collections, Hyperoliidae, type specimens, Zoologisches Museum Berlin

\section{Introduction}

The amphibian collection of the Museum für Naturkunde Berlin (ZMB) is one of the richest in the world, comprising about 60,000 specimens of ca. 2,000 species. One of the largest and most diverse families in the collection is the African frog family Hyperoliidae with approximately 3,500 wet preserved specimens, including about 860 type specimens. These specimens have been used by various authors as a basis for 145 first descriptions, reflecting several periods of research on reed frogs by staff herpetologists and external researchers associated with the ZMB collection.

The oldest specimens from this family present in the collection are from South Africa. These vouchers, sent by G. L. E. Krebs (1792-1844), are two
Hyperolius horstockii (ZMB 3061) from the "Cap". These specimens either were part of a shipment by Krebs containing 90 "Amphibien", in addition to other natural history specimens, and arrived at the museum on 21 June 1830 , or they were acquired by the Zoologisches Museum Berlin from Krebs' collections, auctioned after that date until April 1840 (Lichtenstein "Eingangsjournal ZMB" [acquisition catalogue], see also Bauer 2000). Other old representatives of reed frogs are the species described by W. C. H. Peters (1815-1883) from his Mozambican collections, i.e. Hyperolius variegatus collected first in June 1843 on the Cabaceira Peninsula (see below and Peters $1882 \mathrm{~b}$ ) and five syntypes of $H$. picturatus Peters, 1875 (ZMB 3063, 76991-76994) collected at "Boutre" [Butre (Bootry), Ahanta West District, Western Region, 
Ghana] by the zoologist and colonial administrator of the Dutch Gold Coast, H. S. Pel (1818-1876). Pel, who stayed in the Gold Coast (modern Ghana), from March to April 1841, March 1842 to December 1843, in January 1844, and from September 1847 to November 1850, collected natural history objects for the Rijksmuseum van Natuurlijke Historie in Leiden (Holthuis 1968). In March 1849, the Leiden Museum probably exchanged Pel's specimens together with other herpetological and ichthyologcial objects with the Zoologisches Museum Berlin (Lichtenstein "Eingangsjournal ZMB"). The first mention of Hyperolius species from the ZMB was in the catalogue published by Lichtenstein and Martens (1856: 36) "Nomenclator Reptilium et Amphibium Musei Zoologici Berolinensis".

During the second half of the $19^{\text {th }}$ century, the collection was enriched by material collected, for example, by R. W. Buchholz (1837-1876) and G. A. E. Reichenow (1847-1941) in Cameroon, by C. C. von der Decken (1833-1865) in East Africa and by H. W. L. Dohrn (1838-1913) in Liberia. Several objects from the collection of J. A. de Oliveira Anchieta (1832-1897) from Angola were received in exchange with J. V. Barbosa du Bocage (1823-1907) from Lisbon. Wilhelm Peters undertook the first scientific work on the Berlin Hyperolius material based on his own collections from Mozambique and specimens purchased from the aforementioned collectors (Peters 1854, 1867, 1875, 1876, 1877a, 1878, 1882a, b).
However, most hyperoliid frogs now present in ZMB were collected during the period from 1873 to 1918 in Germany's African colonial territories, and during further expeditions to other regions of the African continent, such as the "Loango-Expedition" (1873-76), J. M. Hildebrandt's Expeditions to East Africa (1873-77), the "Emin Pasha Expedition" (1890-92), the "Togo-Hinterland-Expedition" (1894-95), the "Nyassa-See- und Kinga-Gebirgs-Expedition" (1898-99), the "Kunene-Sambesi-Expedition" (1899-1900), the "German-French Border Expedition" (1901-02), the "Lübecker Pangwe-Expedition" (1907-09), and the "Lagone-Pama-Expedition" (1912-13). Important collectors which need to be mentioned in this context are K. M. E. G. W. Adametz (1877year of death unknown), E. R. R. Baumann (1871-1895), R. Böhm (1854-1884), L. F. W. E. Conradt (life dates unknown), C. A. Denhard (1852-1929), C. V. H. von Erlanger (1872-1904), F. G. H. H. Fülleborn (1866-1933), R. Grauer (1870-1927), H. Grote (1882-1951), J. M. Hildebrandt (1847-1881), P. Hösemann (1868-1922), R. F. P. Hübner (1869-1961), R. Kandt (1867-1918), G. Martienssen (life dates unknown), F. W. A. von Mechow (1831-1904), O. R. Neumann (1867-1946), W. A. von Raven (1875-1928), G. R. O. Scheffler (life dates unknown), J. G. H. Schubotz (1881-1955), P. W. H. Spatz (1865-1942), F. L. Stuhlmann (1863-1928; Fig. 1), G. T. Tessmann (1884-1969), W. Tiesler (life dates unknown), and G. A. Zenker (1855-1922).

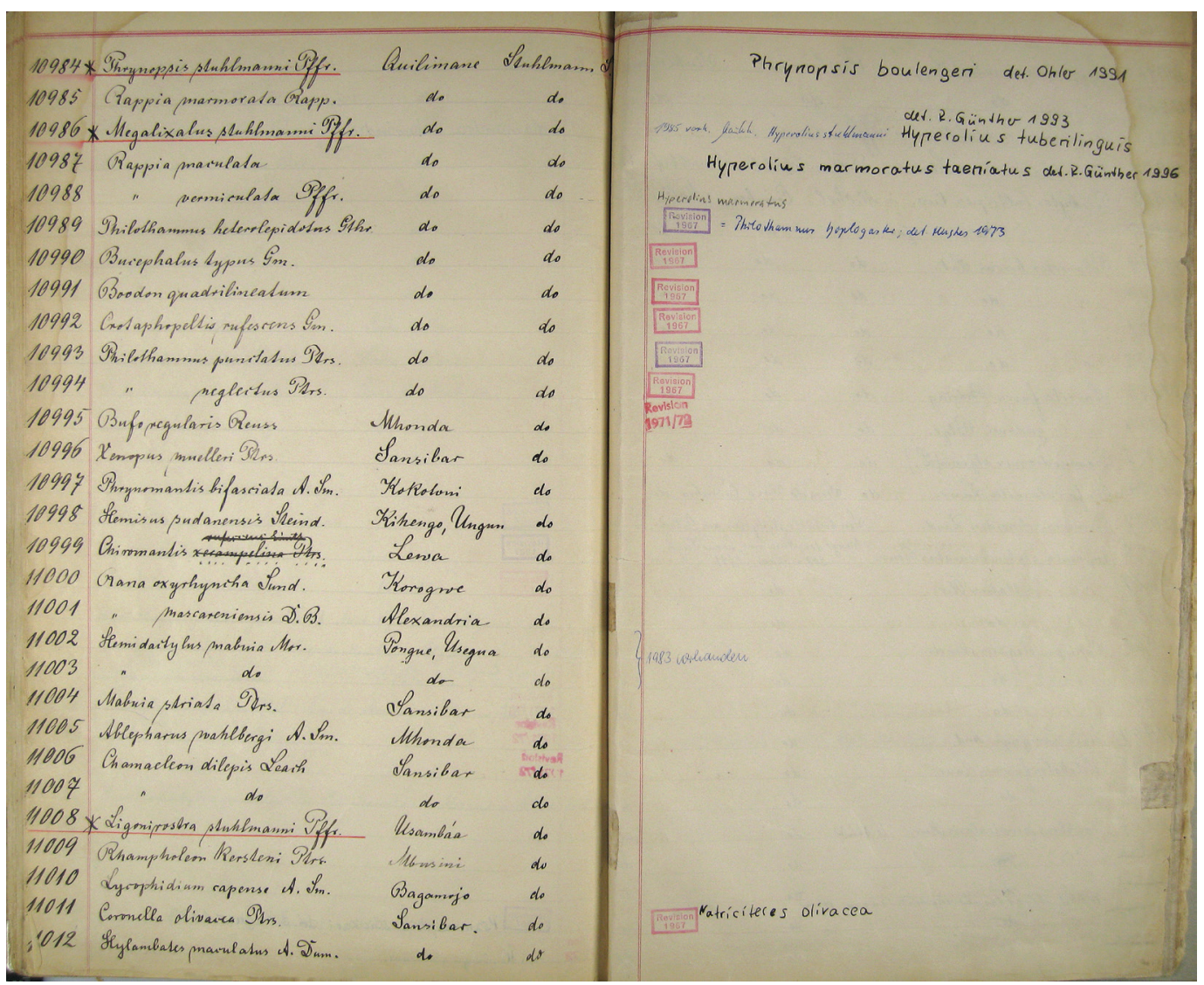

Figure 1. Examplary page from the first numerical inventory catalogue of the herpetological collection at ZMB, with entries of material collected by F. L. Stuhlmann in East Africa. 
At the end of the $19^{\text {th }}$ century, Gustav Tornier (18591938), at the time curator of the amphibian and reptile collection at the ZMB, took over the task of a systematic analysis of the herpetological material collected from colonial German East Africa. In addition to the Berlin collection, he also had access to F. Stuhlmann's collections at the Museum Hamburg. Johann Georg Pfeffer (18541931) from Hamburg, who had originally been assigned this task, resigned for health reasons (Tornier 1896, see also remarks on $H$. flavoguttatus). The extensive colonial material in Berlin and Hamburg, which was particularly rich in reed frogs, enabled Tornier to compile an overview of the "Farbkleid der Rappienhaut" [color pattern of the reed frog skin] (Tornier 1896, plate 4, reproduced here in Fig. 2). In contrast to Ahl, who studied the Berlin reed frog collection three decades later (see below), with one exception, Tornier did not introduce new species names, but rather reported cautiously with regard to the number of (new) species present in the material examined (1896: 156): Sobald die von mir aus Afrika erwarteten Rappiensendungen eingetroffen sind und ich das Rappienmaterial gesehen habe, welches die Hauptmuseen Europas beherbergen, komme ich in einer besonderen Arbeit auf diese Frage zurück. [As soon as the expected Rappia shipments from Africa have arrived, and I have seen the Rappia material housed by the major European museums, I will return to this question in a special study]; however, this study was never compiled and published.

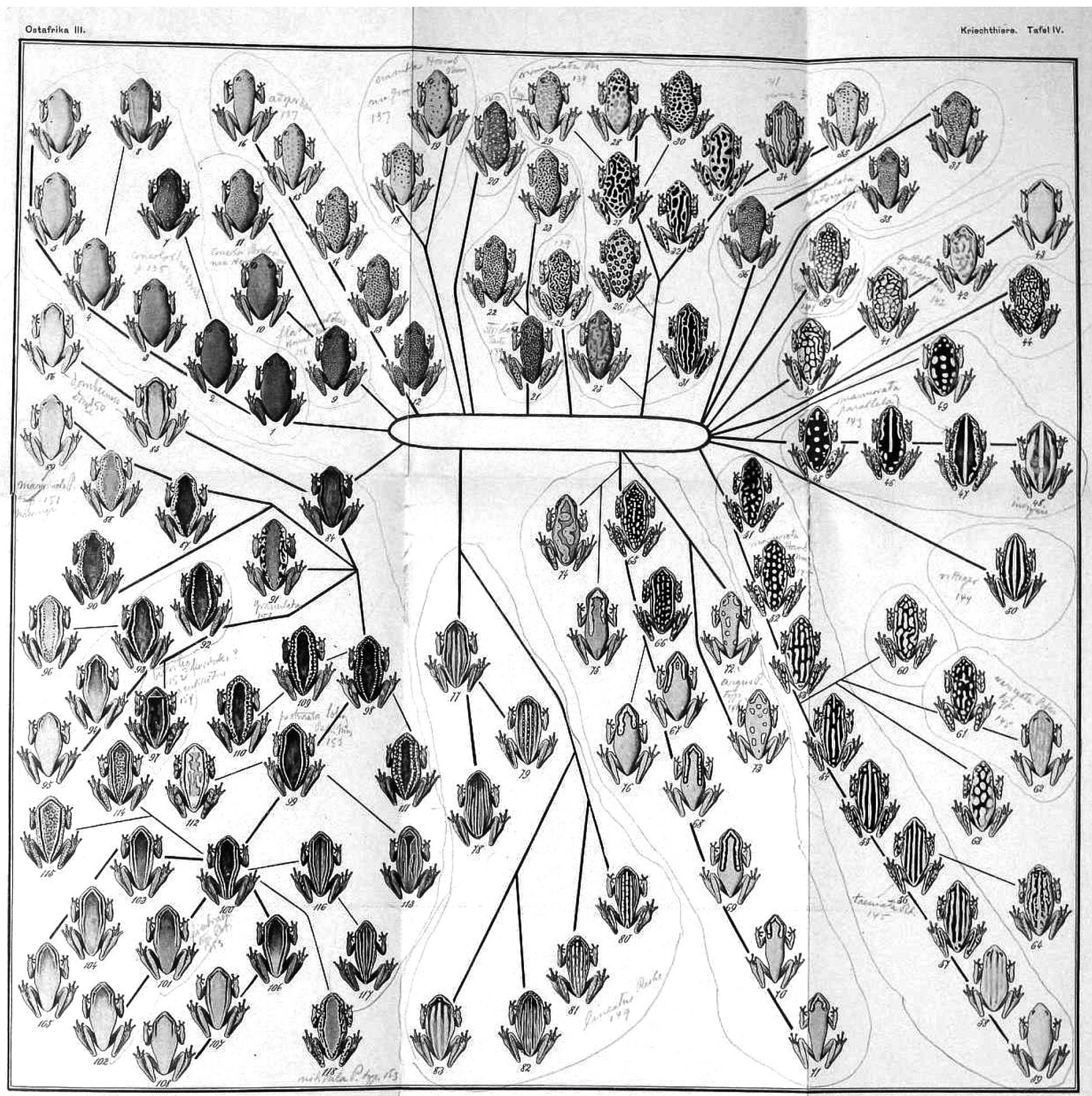

Figure 2. "Farbkleidmuster der Gattung Rappia" [color pattern of the genus Rappia (Hyperolius species)], reproduced from Tornier (1896, pl. 4). 
A decade later, at the beginning of $20^{\text {th }}$ century, large scale research expeditions such as the first and second "Deutsche-Zentral-Afrika-Expedition" [German-Central-African-Expedition] from 1907-08 and 1909-10, provided rich new material. Together with specimens obtained from the German colony Cameroon, further remarkable collections of amphibians and reptiles, including considerable numbers of reed frogs, were sent to ZMB, and were partly described by Friedrich Erich Gottlieb (called Fritz) Nieden (1883-1942) (Nieden 1910a, 1913; see also Günther and Bischoff 2018).

In December 1921, Christoph Gustav Ernst Ahl (1898-1945) started to work as a voluntary scientific assistant in the ichthyological and herpetological department of ZMB. After Tornier's retirement, Ahl became an official assistant from February 1923 to September 1927. From October 1927 until his dismissal in March 1941, he was employed as senior scientific assistant in the herpetological department of ZMB. During his career, Ahl published a total of 302 new descriptions of amphibians and reptiles (Paepke 2013). Over a period of seven years, he described 106 nominal taxa from the family Hyperoliidae (Ahl 1924, 1930a-d, 1931a), and worked on this family monographically, published as part 55 of the "Tierreich" [animal kingdom] series (Ahl 1931b). However, Ahl's work is overshadowed by a large number of scientifically flawed descriptions. A selection of Ahl's Hyperolius types were sent in exchange to the Museum of Comparative Zoology at Harvard University (MCZ) in 1932, and this material allowed Barbour and Loveridge (1947) and Loveridge (1957) to synonymize 50 of Ahl's species. Arthur Loveridge (1957: 157, 324) called Ahl a "reckless describer" and complained about his insufficient knowledge of intra-specific variability within the Hyperoliidae as well as his inadequate comparisons with already described species. Ahl's working methods and the quality of his descriptions have subsequently been commented on, e.g. by Glaw and Vences (1992), Paepke (1995, 2013), Rieck (2001), and Adler (2007). In addition to Ahl's questionable scientific approach, many of the (type) specimens mentioned by him (Ahl 1931a, b) were not inventoried and placed in the systematic collection during his tenure; instead, these were often placed on the shelves of undetermined material, sometimes with handwritten notes. In the 1950s Heinz Wermuth (1918-2002), then curator of herpetology at ZMB, at the request of Raymond Ferdinand Louis-Philippe Laurent (1917-2005), endeavored to locate Ahl's type material. In September 1958 and January 1959, a total of $244 \mathrm{Hy}$ perolius specimens, including the locatable types, were sent on loan to Laurent at the "Université Officielle du Congo-Belge, Elisabethville" [Lubumbashi, Democratic Republic of the Congo]. Based on this material Laurent (1961) published a paper on the Hyperolius and Afrixalus in the ZMB. He reviewed some of Ahl's taxa and mentioned for the first time respective inventory numbers. In the introduction of this paper he suggested that it would be desirable to declare all descriptions based on the activ- ity of this individual zoologist [Ahl] as nomina confusa (see also comments in Liedtke et al. 2014: 254).

Several 'Ahl species' were synonymized by Loveridge (1942, 1957); Laurent $(1943,1958,1961)$ and Barbour and Loveridge (1947). Other herpetologists studied Berlin hyperoliid specimens in the second half of the $20^{\text {th }}$ century. Among them were Arne Schiøtz (1932-2019) from the Zoological Museum Copenhagen, who got material on loan in 1960 and 1961, and visited the ZMB in 1968 in order to study the East African frog collection, and Jean-Luc Perret from the Natural History Museum Geneva, who borrowed a number of Ahl types in 1962, and visited the ZMB collection in 1974. As a result of their studies, further 'Ahl species' were synonymized (see e.g. Schiøtz 1967, 1975). Only $24 \%$ of the reed frogs described by Ahl are still considered valid (see below; Paepke 2013; Frost 2021).

After 2000, ZMB received new hyperoliid vouchers from West and Central Africa, as well as from Mozambique, mainly through the collections of the working group of Mark-Oliver Rödel, curator of herpetology at ZMB since 2007. J. M. Dehling (University Koblenz-Landau) provided new vouchers from Rwanda, V. Mercurio (Berlin) collected in Malawi, and A. Channing (University of the Western Cape) sent vouchers from South and East Africa. The study of these new collections and the re-evaluation of historic specimens resulted in a number of revisions and new descriptions (see e.g. Lötters et al. 2004; Rödel et al. 2003, 2009, 2010; Dehling 2012; Channing et al. 2013; Frétey et al. 2014; Liedtke et al. 2014). These and other studies, often based on 'new' molecular technologies, also revealed that the diversity within the Hyperoliidae might be much higher than previously assumed and comprise a large number of cryptic taxa (i.e. Channing et al. 2013; Portik et al. 2019). Thus it is likely that some of the ZMB 'synonyms' actually refer to valid species (see Rödel et al. 2010). Current researchers describing new African reed frogs tend to ignore the availability of these names because these are listed as either synonyms or lost by Frost (2021). However, the collection of hyperoliid frogs in ZMB was never fully reviewed and the status of several taxa and the presence of many type specimens remained unevaluated. For instance, no fewer than 17 nominal taxa have been reported lost or not traced by Frost (1985) or listed as originally present in ZMB but without inventory number (Frost 2021).

We present a list of existing and so far unlocated type specimens of 146 nominal taxa of the family Hyperoliidae from the ZMB collection of which 130 are primary types (88 holotypes, 10 lectotypes and 32 taxa based on series of syntypes), 50 of which are currently considered valid. Primary types of nine taxa could not be located. Seven taxa are represented by secondary types (paratypes) only. This summary is not intended to resolve pressing taxonomic issues that in many cases will require dedicated research using molecular genetic approaches (see Scherz et al. 2020 for a promising example). In some cases, however, we added observations of taxonomic value (e.g. 
measures and character descriptions), clarified priority of names, and identified and corrected type localities when possible. Our aim is to present what is available for study to aid future research that describes and names new taxa in the Hyperoliidae. This contribution is the third catalogue on the amphibian types held by ZMB. Previous catalogues include the caecilians and salamanders (Bauer et al. 1993), as well as the hemisotid, microhylid, myobatrachid, pelobatid and pipid frogs (Bauer et al. 1996).

\section{Methods}

From 2017 to 2020, all specimens from the family Hyperoliidae in the collection of the Museum für Naturkunde Berlin (ZMB; in some publications the Museum für Naturkunde is also abbreviated with MfN or other acronyms (see Sabaj 2020); to avoid confusion, we apply the traditional use of ZMB for the herpetological collection) were systematically digitally registered, including all specimens not previously inventoried. Lots - jars with specimens all carrying the same accession number-were individualized and each specimen was assigned an individual number. Details on the original field labels were compared to catalogue entries, information from the accession catalogues and the data were completed where necessary. ZMB numbers always refer to the final inventory catalogue numbers. In addition, we sometimes mention 'accession numbers'. These are separate catalogues used in the herpetological department from ca. 1856 to April 1940, to record the accession of new material, often registered in lots with "C-Catalogue" numbers (Fig. 3). Only after having been assigned a 'ZMB number' are vouchers finally inventoried. The terms 'Register Catalogue' or 'ZMB Register' refer either to the accession catalogues of the Zoological Library or to Lichtenstein's 'Eingangsjournal' for the entire Zoological Museum, the latter archived in the Department of Historical Research at the Museum für Naturkunde (see Unpublished Sources). Our digital accessioning of the specimens, in connection with information on collectors, localities and collection periods, made it possible to search for previously unlocated type specimens of the species described by Ahl (1931a). For primary type specimens, the type localities and the collectors were identified whenever possible. Secondary types from the Berlin collection are likewise listed with locality and collector. If not stated otherwise, we follow Frost (2021) regarding the currently valid names. Concerning type localities, we always provide first the original spelling (in quotation marks) followed by the currently applied name of the locality in brackets, as well as further geographic data, such as province and country.

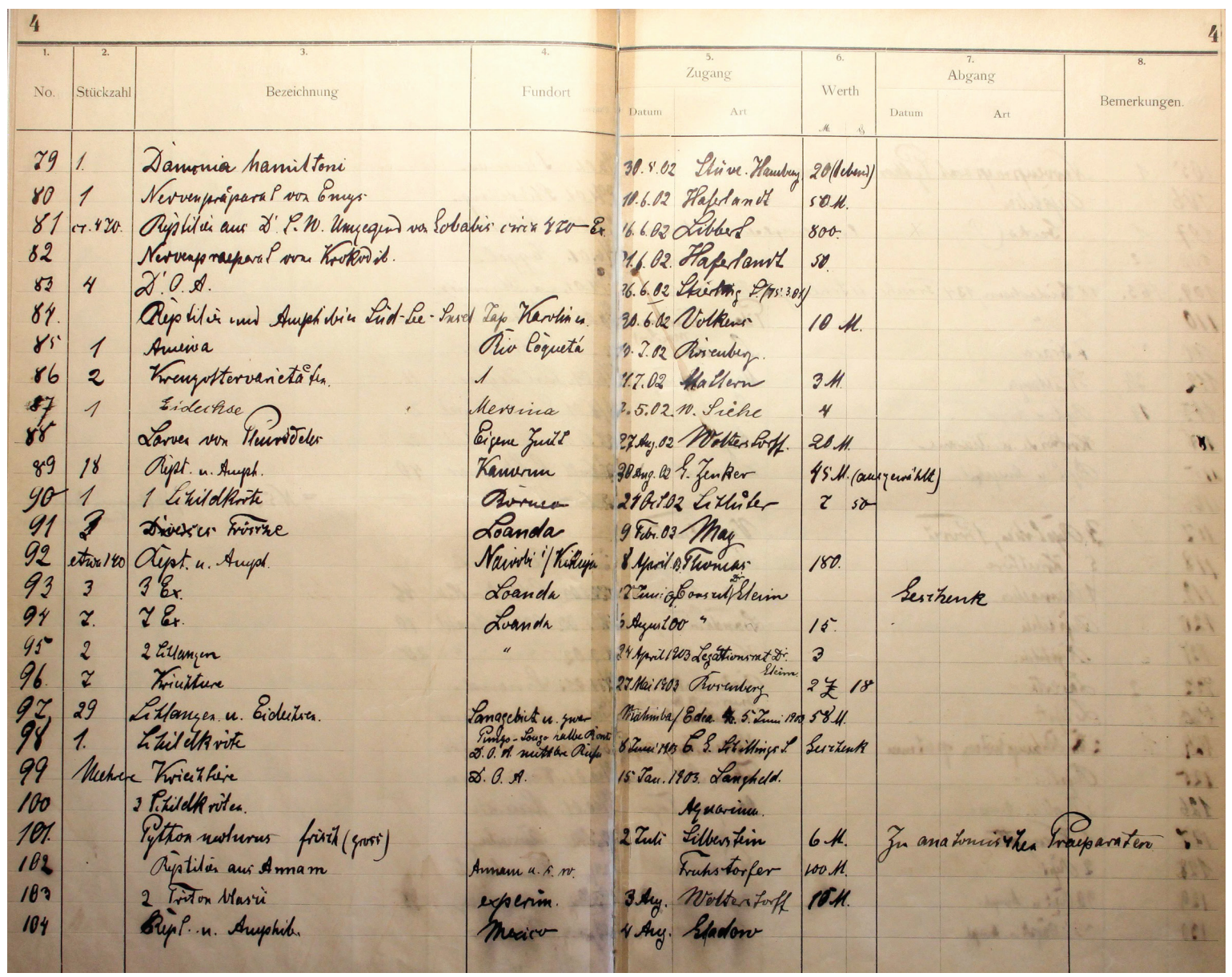

Figure 3. Examplary page from the second numerical accession catalogue (= "C" catalogue) of the herpetological collection at ZMB, with entries of African material collected by e.g. O. Gleim, W. Langheld, C. May, F. Thomas and G. A. Zenker. 
We list all types in alphabetic order, using the original name in the description. The present taxonomic status and generic association is given under 'present name' in each species account. Remarks in the individual species accounts contain information on illustrations of the type material, the activities of the collectors, and the collection periods as well as information taken from secondary literature on additional type material that is not housed in the ZMB collection. We omit providing information on the history of the synonymy of the respective taxa. This is provided by Frost (2021) and can be consulted at: https:// amphibiansoftheworld.amnh.org/index.php. It is important to note that we herein do not take any taxonomic decisions; we present the available type specimens and their current taxonomic name. For valid names we refer, with few exceptions, to Frost (2021). Until the complex taxonomy of the $H$. marmoratus species group is solved and allows a more accurate assignment, we tentatively follow Marques et al. (2018) and list Angolan taxa previously considered as synonyms of $H$. marmoratus Rapp, 1842 or H. parallelus Günther, 1858 as belonging to Hyperolius angolensis Steindachner, 1867. Ceríaco et al. (2020: 395 ) confirm assignment of Angolan frogs of the H. marmoratus group to H. angolensis. In contrast Frost (2021) and Baptista et al. (2019) regard H. angolensis as a junior synonym of $H$. parallelus Günther, 1858. An even more conservative approach has recently been applied by Channing and Rödel (2019), treating almost all populations of the Hyperolius viridiflavus/marmoratus-complex as $H$. viridiflavus.

Recently, Dubois et al. (2021) suggested 'new concepts and methods for phylogenetic taxonomy and nomenclature', using Lissamphibia as a template. To avoid causing further confusion in an already complex and taxonomically confusing group of tropical tree frogs, we - without assessing the new system - refrain herein from following Dubois et al. (2021). The future will show if researchers will accept and apply this new concept.

In the chapter "Specimens erroneously marked as types in ZMB inventory catalogues", we mention names which are labeled as types in the inventory catalogues of the Herpetological Department of ZMB. To our knowledge, these names were never published by the authors to which these names are attributed, nor by anyone else. These names are thus placed in quotation marks and not italicized to indicate that they are not used as valid. Since these names were sporadically used (e.g. Schiøtz 1975) we list them here and clarify the identity of the specimens if possible.

It is important here to provide commentary on the publication history of Ahl's (1931a, b) works on hyperoliid frogs and how that relates to priority of the species names published therein. In 1931, Ahl published two monographs: the paper "Zur Systematik der afrikanischen Baumfroschgattung Hyperolius [Towards the systematics of the African tree frog genus Hyperolius] (Ahl 1931a)“" as well as Lieferung [issue] 55 „Anura III“ from the 'animal kingdom" series ["Das Tierreich"] (Ahl 1931b). The later work covered all known frog species of what today is accepted to be the family Hyperoliidae. However, it has never been fully clarified which of these monographs was published first, and thus which of these two publications serves as the original publication for making available the Hyperolius species names described by Ahl in 1931. We thus researched respective entries in the zoological main library of ZMB and in the reprint collection of the herpetological department. On the front covers of both publications we found the following notes on publications dates: volume 17, issue 1 of the "Mitteilungen aus dem Zoologischen Museum in Berlin" (Ahl 1931a) was published on 1 April 1931; Lieferung (volume) 55 of Anura III of the series "Das Tierreich" (Ahl 1931b) was published in March (März) 1931 (Fig. 4). Later, these publication dates were often overlooked or ignored. Hence numerous authors gave priority to the names published in Ahl's Lieferung 55 of the „Das Tierreich“ (e.g. Laurent 1941, 1958; Loveridge 1942, 1953, 1957; Barbour and Loveridge 1946; Manaças 1949, Perret and Mertens 1957; Schiøtz 1975; Frost 1985; Channing and Howell 2006; Pickersgill 2007a; Seniagbeto et al. 2007; Mercurio 2011; Dehling 2012; Paepke 2013; Frétey et al. 2014; Liedtke et al. 2014; Marques et al. 2018), others however, regarded the names published in the "Mitteilungen vol. 17(1)" as having priority (e.g. Loveridge 1936a, b; Laurent 1943; Schiøtz 1967; Perret 1976b; Pakenham 1983; Rödel 1996; Lötters et al. 2004; Rödel et al. 2010; Amiet 2012). Frost (2021) states “The description in Ahl, 1931[a], Mitt. Zool. Mus. Berlin, 17 [...], appeared a few weeks later according to unpublished notes by A. Loveridge (fide R. Laurent)." These personal notes and comments by Arthur Loveridge and Raymond Laurent correspond with the printed publication dates on the front covers of the two publications, as has been already commented on by Barbour and Loveridge (1946, p. 126).

However, it needs to be emphasized that, without doubt, Ahl intended to publish the paper "Zur Systematik [...]" (Ahl 1931a) ahead of the "Anura III" (Ahl 1931b). For instance: i) in the preface of his paper" Zur Systematik $[\ldots]^{\text {" }}$ he refers to the ,soon to be published monograph within the ,animal kingdom series' [,demnächst erscheinende Monographie im "Das Tierreich"']; ii) in the paper he added ,spec. nov." to the new names, in the species accounts of "Das Tierreich" this is not added, and iii) lastly comments concerning the distribution of species are generalized in "Das Tierreich" and data concerning type material and collectors are lacking completely (but are provided in "Zur Systematik [...]").

To finally clarify the history of both publications (Ahl 1931a, b), we checked the original prints and Eingangsregister (accession catalogues) in the department of herpetology and the zoological library at ZMB. Based on the receipt stamps on the original prints (journal issue and reprints) as well as the notes in the Eingangsregister [entry register] of the zoological library, it is obvious that volume 17, issue 1 of the "Mitteilungen aus dem Zoologischen Museum in Berlin" was received on 11 April 1931. In contrast Lieferung 55, Anura III from "Das Tierreich" was only received a month later on 11 Mai 1931. Article 21.4 of the 'Code' (ICZN 1999) clarifies that "If 


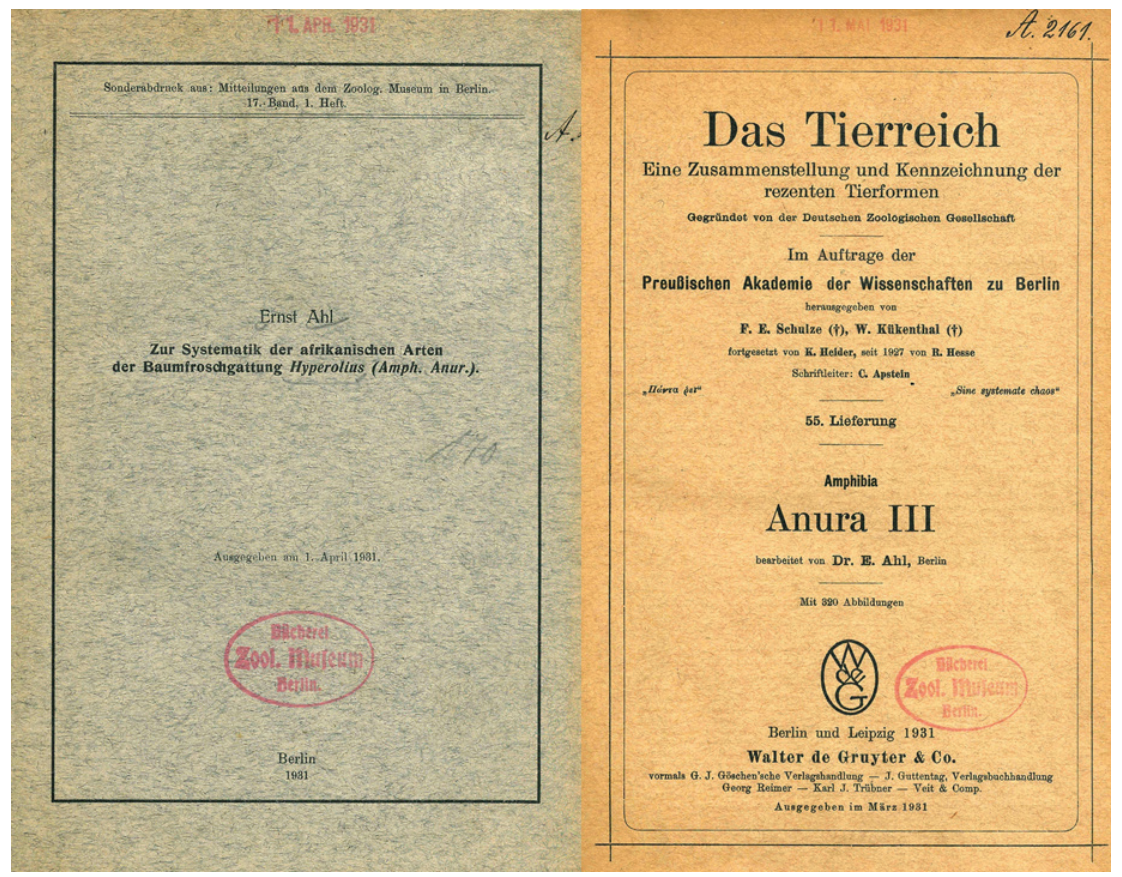

Figure 4. Titlepages of Ahl (1931a) "Mitteilungen..." and Ahl (1931b) "Das Tierreich" with printed dates of publication at the bottom and receipt stamps of the zoological library at ZMB with date of availability at the upper edge; compare text.

the date of publication specified in a work is found to be incorrect, the earliest day on which the work is demonstrated to be in existence as a published work is to be adopted". Furthermore, Recommendation 21D states that "A librarian should not remove, or allow to be removed by a binder, the cover or pages bearing information relevant to the date of publication, the contents of the work or its parts, or the day or dates of receipt by the library." This makes the receipt dates from the ZMB library relevant in this context. We thus follow Recommendation $21 \mathrm{~F}$ of the 'Code' and correct the publication dates which gives the names published by Ahl (1931a) in the "Mitteilungen $[\ldots]$ " priority.

\section{Abbreviations}

Institutional codes following Sabaj (2020):

BMNH [NHMUK] Natural History Museum, London (formerly: British Museum (Natural History));

MCZ Museum of Comparative Zoology, Harvard University, Cambridge;

MBL Museu Bocage [Museu Nacional de História Natural], Lisboa;

MHNG Muséum d'Histoire naturelle, Genève; MHNN - Naturhistorisches Museum Mainz;

MNHN Muséum national d'histoire naturelle, Paris;

MSNG Museo Civico di Storia Naturale "Giacomo Doria" [Civic Museum of Natural History], Genova [Genoa];

NMW Naturhistorisches Museum Wien, Vienna;

PEM Port Elizabeth Museum, Bayworld, Port Elizabeth;
RMNH Naturalis Biodiversity Center (formerly Rijksmuseum van Natuurlijke Historie], Leiden;

SAIAB South African Institute of Aquatic Biodiversity, Grahamstown;

SMF Senckenberg Forschungsinstitut und Naturmuseum, Frankfurt am Main;

SMNS Staatliches Museum für Naturkunde, Stuttgart;

ZFMK Zoologisches Forschungsmuseum Alexander Koenig, Bonn;

ZMB Museum für Naturkunde Berlin, Leibniz Institute for Evolution and Biodiversity Science (formerly: Zoologisches Museum Berlin);

ZMG Zoologisches Institut und Museum der Universität Greifswald;

ZMH CeNak (Center of Natural History), Zoologisches Museum, Universität Hamburg (formerly: Zoologisches Museum Hamburg; presumably from 1 July 2021 on, ZMH and ZFMK will fuse to LIB: Leibniz-Institut zur Analyse des Biodiversitätswandels);

ZMUC Universitets København, Zoologisk Museum, København;

ZSM Zoologische Staatssammlung München, Munich.

\section{Results}

\section{Extant types}

Afrixalus fornasini see Hyperolius bivittatus.

Afrixalus brevipalmatus see Hyperolius brevipalmatus. 
Afrixalus dorsalis

see Hyperolius dorsalis.

Afrixalus dorsimaculatus

see Megalixalus dorsimaculatus.

Afrixalus laevis

see Megalixalus laevis (unlocated type specimens).

Afrixalus stuhlmanni

see Hyperolius pygmaeus, Hyperolius unicolor, Megalixalus stuhlmanni.

Afrixalus uluguruensis

see Megalixalus uluguruensis.

Afrixalus vittiger

see Hyperolius vittiger.

\section{Acanthixalus sonjae Rödel, Kosuch, Veith \& Ernst,} 2003: 44.

Paratypes. ZMB 74985 and ZMB 79340, "SRET [Station de Recherche en Écologie Tropicale] station transect $\mathrm{X}$, large water-filled tree stump, secondary forest, Taï National Park, Ivory Coast, $5^{\circ} 50^{\prime} \mathrm{N}, 7^{\circ} 20^{\prime} \mathrm{W}^{\prime}$, coll. Raffael Ernst and Mark-Oliver Rödel, 16.IX.2000.

Present name. Acanthixalus sonjae Rödel, Kosuch, Veith \& Ernst, 2003.

Remarks. Holotype: SMNS 09573, "SRET station transect X, large water-filled tree stump, secondary forest, Taï National Park, Ivory Coast, $5^{\circ} 50^{\prime} \mathrm{N}, 7^{\circ} 20^{\prime} \mathrm{W}$ ', coll. Raffael Ernst and Mark-Oliver Rödel, 16.IX.2000. Additional paratypes: SMNS 09574.1-2, "Noe-Grid, Taï National Park, Ivory Coast, $5^{\circ} 50^{\prime} \mathrm{N}, 7^{\circ} 20^{\prime} \mathrm{W}$ ”, coll. Raffael Ernst and Mark-Oliver Rödel, 16.IX.2000 and SMNS 09575.1-28, same collecting data as for the holotype; ZSM 9080/2001, same collecting data as for the holotype (Glaw and Franzen 2006); PEM A7414, "Forêt Classé de Haute Dodo, 454'03"N, 7¹9'3"W, coll. William Roy Branch and Mark-Oliver Rödel, 15.III/2002 (Conradie et al. 2015); and "three males, two females and four juveniles alive, same data as holotype; numerous tadpoles alive". The two Berlin paratypes (ZMB 79340 and 74985) were formerly part of the aforementioned mentioned series of uncatalogued paratypes.

\section{Acanthixalus spinosus \\ see Hyperolius spinosus.}

\section{Cystignathus argyreivittis Peters, 1854: 626.}

Lectotype. ZMB 4426, "Boror" [Companhia do Boror, Zambezia Province, Mozambique], coll. Wilhelm Carl Hartwig Peters.

Paralectotypes. ZMB 10106 and ZMB 85708 (formerly part of ZMB 10106), "Cabaceira" [Peninsula
Cabaceira, Mossuril District, Nampula Province, Mozambique], coll. Wilhelm Carl Hartwig Peters.

Present name. Kassina senegalensis (Duméril \& Bibron, 1841).

Remarks. Peters (1854) does not mention the number of specimens available to him for the description, but later he specified that he found "[...] drei weibliche Exemplare, eins auf der Halbinsel Cabaceira, zwei in Boror, während des Märzmonats, in feuchtem Grase." [... three female specimens, one on the Cabaceira Peninsula, two in Boror, during the month of March, in wet grass] (Peters 1882b: 158). One of the former syntypes is depicted in Peters (1882b, pl. 22, fig. 2, and on pl. 26, fig. 3, sternum). Bauer et al. (1995: 43) consider the specimens inventoried under ZMB 4426 and ZMB 10106 to be syntypes. Frost (2021) mentioned only ZMB 4426 as syntype and refers to other unnumbered syntype(s) in the ZSM collection. However, Glaw and Franzen (2006) do not mention syntypes of Cystignathus argyreivittis present at ZSM. Ahl (1930c: 283) denotes [ZMB] 4426 as "Typus" and [ZMB] 10106 (two specimens) as "Cotypen" of Cystignathus argyreivittis. This constitutes a lectotype designation of ZMB 4426 from "Boror" (ICZN 1999: Art. 74.5).

W. C. H. Peters, a zoologist, anatomist and later director of ZMB (from 1857 to 1883) undertook a journey to Mozambique from September 1842. Via Portugal and Luanda (Angola) he reached Mozambique Island on 17 June 1843. During his stay in Mozambique, he undertook various short trips, e.g. to Zanzibar, Anjuan (Comores), Saint Augustin (Madagascar) and South Africa. On August 7, 1847 he left Mozambique and sailed via Goa and Mumbai (India), Candy (Sri Lanka) and Egypt to return to Berlin in early 1848 (itinerary and map in Bauer et al. 1995). Already during his journey, Peters regularly sent his collections back to Berlin, some of which were donated to the Anatomical Museum, the majority was given to the ZMB and a number of doublets ("Doubletten") were sold (Brauer 1910; Bauer et al. 1995).

\section{Heterixalus betsileo see Hyperolius friedrichsi.}

\section{Heterixalus variabilis \\ see Megalixalus variabilis.}

\section{Hyperolius acuticephalus Ahl, 1931a: 131.}

Holotype. ZMB 30999; "Ngoto, Lobajegebiet" [Kembé, Basse-Kotto Prefecture, Central African Republic]; coll. Günther Theodor Tessmann, 30.X.1913.

Present name. Hyperolius acuticephalus Ahl, 1931.

Remarks. Depicted in Ahl (1931b: 419, fig. 291). The German botanist, ethnologist and explorer Tessmann travelled to Cameroon in 1904, where he worked until 1905 for the West African plantation company Bibundi as a supervisor on a cocoa plantation. Afterwards he travelled to the Cameroon Hinterland [,Hinterland' is a term in the colonial literature, used in various languages; 
it does not specify a specific geographic region but refers generally to regions being away from the coast or provincial towns] and to Yaoundé and founded his own plantation in the border area between German-Cameroon and Spanish-Guinea. From 1907 to 1909 he was the head of the "Lübecker Pangwe-Expedition" to South Cameroon and Equatorial Guinea and in 1913 he led an expedition to "Neu Kamerun". During the First World War he fled to Spanish Guinea and was interned by the Spanish on Fernando Pó [Bioko]. Later, he turned to South America, travelled through Peru, and emigrated to Brazil in 1936, where he settled in the state of Paraná and got a position at the Museu Paranaense. During his stay in Africa he collected large numbers of zoological, botanical and ethnological objects, most of which were sent to the museums in Berlin and Lübeck (Dinslage and Templin 2012; Dinslage 2015; Templin 2015).

Hyperolius acuticephalus could be conspecific with either H. igbettensis Schiøtz, 1963 or H. adsperus Peters, 1877. Type locality and shape of head better fit $H$. igebettensis (fide Channing et al. 2013); concerning webbing of feet $H$. acuticephalus is intermediate between $H$. igbettensis and $H$. adspersus (fide Channing et al. 2013); the ratio of head width/snout-vent length speaks in favor of $H$. adspersus (fide Amiet 2012); and the ratio of head length/ head width points again to $H$. igbettensis (fide Amiet 2012); finally the value for the length of the snout/head width surpasses both $H$. igebettensis and $H$. adspersus.

\section{Hyperolius acuticeps Ahl, 1931a: 29.}

Syntypes. ZMB 36039 and ZMB 65176 (formerly part of ZMB 36039), "Konde-Nika" [Region at the northern tip of Lake Malawi, Mbeya and Njombe Region, Tanzania], coll. Friedrich Georg Hans Heinrich Fülleborn, 02.VI.1900.

Present name. Hyperolius microps Günther, 1864.

Remarks. Drawing in Ahl (1931b: 282, fig. 153). For the location of "Konde-Land" we refer to Fülleborn (1906: $268 \mathrm{ff}$.), who describes it as a small area at the northern tip of Lake Malawi as follows: limited in the east by Lake Malawi, in the northeast by the slopes of the Livingstone Mountains [Kipengere Range], in the southeast by the Untali and Malila Mountains, in the north by Rungwe Volcano and in the south by the lower reaches of the Ssongwe (Songwe River).

In 1896, the German physician, doctor of tropical medicine, and explorer Fülleborn joined the colonial "Schutztruppe" in German East Africa, where he was active as a government physician until 1901. From April 1897 to the beginning of 1898 , he participated in the military campaigns against the Wangoni and Wahehe of the "Ungoni", "Uhehe" and "Ubena" regions, in present day southern Tanzania. From 1898 to 1899 Fülleborn was stationed in Langenburg [Lumbira, Mbeya Region, Tanzania] in the north of Lake Malawi and undertook numerous excursions in the surrounding area, which took him to the southern end of Lake Malawi, through the "Schire-
Hochländer" [Shire Highlands, southern Malawi], and on the Shire and Zambezi River to Quelimane and afterwards to the Island of Mozambique. In 1899 he was commissioned to research the "German-Nyassa" region from a zoological and ethnological-anthropological point of view. Together with W. Goetze he participated in the "Nyassa-See- und Kinga-Gebirgs-Expedition" (Engler 1902; Fülleborn 1906; see also comments on Hyperolius goetzei). During this time Fülleborn also surveyed Lake Malawi and the lakes in northern Nyasaland (Rukwa, Chungruru, Itende) and collected a considerable number of mammals, about 800 birds, more than 1000 fishes, amphibians and reptiles, thousands of insects and other invertebrates, and particularly plankton (Fülleborn 1900a, b; Paepke and Seegers 1995). The majority of these collections were donated to ZMB. Fülleborn's extensive herpetological collections were partly studied in the first third of the $20^{\text {th }}$ century by former curators of herpetology at ZMB (e.g. Ahl 1929, 1931a, c; Tornier 1900, 1902, 1905). However, many specimens remained unexamined on the shelves within the 'undetermined material'. On the basis of Fülleborn's diary Hans Paepke (curator emeritus Department of Ichthyology at ZMB) compiled a list of the places where Fülleborn stayed between April 1897 and October 1899. The diary and this list are archived in the Department of Historical Research at ZMB (Zool. Mus. Sign. S III, "Fülleborn, F.").

\section{Hyperolius acutirostris Buchholz \& Peters in Peters, 1875: 207, pl. 2, fig. 4.}

Syntypes. ZMB 8470 and ZMB 65177 (formerly part of ZMB 8470), "Cameruns" [Douala, Region Littoral, Cameroon], coll. Reinhold Wilhelm Buchholz.

Present name. Hyperolius acutirostris Buchholz \& Peters, 1875.

Remarks. Perret (1966: 408) considered the type material of H. acutirostris lost and designated MHNG 965.12 as neotype. Bauer et al. (1995: 43) could only locate one of the two syntypes. The type locality was corrected to "Douala" by Frétey et al. (2014); for further information see also remarks on Hyperolius guttatus.

The German explorer, zoologist and anatomist Buchholz went to Equatorial Africa from 1872 to 1875 . He was accompanied by the Berlin ornithologist Georg Anton Eugen Reichenow and Reichenow's friend, fellow student and zoologist Wilhelm Lühder. On 1 June 1872 they set off from Bremerhaven to "Akkrá on the Gold Coast" [Accra, Ghana], which they reached on 29 July 1872. The first collecting tours took place in the surroundings of Accra and Aburi (29 July to 16 October 1872). On 16 October they left Accra for "Camaroons" [today part of present day Douala city] where they stayed until 2 November. Then they travelled to Bimbia, Victoria and Bonjonjo (2 November 1872 to 9 December 1873). On 12 March 1873 Lühder died of malaria in 'Camaroons'. Reichenow, also suffering from malaria, returned via Gabon to Germany in April 1873. 
Buchholz was on his own from then on. He travelled between Victoria and 'Camaroons' with intermediate stops on Fernando Pó to get his collections to Camaroons in early December.

Thereafter he went to Abo (9 December 1873 to 24 March 1874) and from Mungo via Balong he returned again to 'Camaroons' (5 April to 11 August 1874). He left 'Camaroons' for a stay in Gabon where he also explored the Rembo River (12 August to 9 November 1874). After his return to the Gabon coast he again explored the area around Mungo and Jenssoki (9 November 1874 to 11 January 1875), and again visited Fernando Pó, the Gabon coast and the Ogowe (or Ogooué) River (11 January to 31 August 1875). On 3 September he started from Gabon on his way back to Greifswald where he arrived during the beginning of November 1875 (Reichenow 1874; Heinersdorff 1880; Weidmann 1894; Stresemann 1943). Buchholz' collections went to the zoological museums in Greifswald and Berlin and his herpetological material has been described by Wilhelm C. H. Peters (Peters 1875, 1876).

\section{Hyperolius ademetzi Ahl, 1931a: 37.}

Lectotype. ZMB 20794, "Bamenda" [Mezam Department, Northwest Region, Cameroon], coll. First Lieutenant Karl Moritz Ernst Gustav Wilhelm Adametz, VI/1909.

Paralectotypes. ZMB 77729-77733 and ZMB 77749, same collecting data as for the lectotype.

Present name. Hyperolius ademetzi Ahl, 1931a.

Remarks. Drawing in Ahl (1931b: 296, fig. 171). Originally eight specimens according to the original publication. Lectotype designation by Perret (1962: 244, fig. 2) who provided a photograph of the lectotype. Another paralectotype MCZ A-17626 was sent in exchange from ZMB in 1932 (Barbour and Loveridge 1946: 126). Adametz was a first lieutenant in the German 'Schutztruppe' for Cameroon and head of the colonial station in Bamenda. He was involved in surveying the Hinterland of the Kamerun-Nordbahn in the Bamenda region. In summer 1912, he also took part in an operation against the Baminge (Bamije-Expedition) at the eastern frontier of the present day Manyu Division, Southwest Region, Cameroon (Nkwi 1989; Hoffmann 2007; Hafeneder 2008).

\section{Hyperolius adolphi-friederici Ahl, 1931a: 116.}

Holotype. ZMB 36114, "Rugegewald, 2000 m Höhe" [Nyungwe Forest, Cyangugu Prefecture, West Province, Rwanda], collected during the first "Deutsche ZentralAfrika-Expedition", VIII/1907.

Present name. Hyperolius castaneus Ahl, 1931a.

Remarks. Drawing in Ahl (1931b: 399, fig. 274). Under the leadership of Adolf Friedrich, Duke of Mecklenburg, the first "Deutsche Zentral-Afrika-Expedition" had the goal of scientifically investigating the areas of the western branch of the East African Rift Valley. Among the expedition members who collected herpetological material were Schubotz and Grauer (meeting at Lake Kivu, see also remarks on Hyperolius callichromus) as well as von Raven. On 29 May 1907, the expedition started in Mombasa [Kenya], led via "Port Florence" [Kisu$\mathrm{mu}$ at the northeastern coast of Lake Victoria, Kenya] to "Bukoba" [June 1907, Bukoba Urban District, Kagera Region, Tanzania] on the western shore of Lake Victoria. From here, almost 600 expedition members headed west to "Kifumbiro" [June 1907, a German military post at the ferry over the Kagera River], and to "Rufua" [July 1907, a military post in the northern Mpororo Region, Ntungamo District, Western Region, Uganda]. From here the expedition moved south to the "Mohasi See" [July 1907; Lake Mohasi, Rwanda] and "Niansa" [August 1907] and from there in western direction to the military station "Ischangi" [August 1907; Shangi, Gafunzo, Ruhango District, Southern Province, Rwanda] at the southern tip of Lake Kivu.

Then, the caravan turned north, crossed Lake Kivu with a stop at "Kwidschwi" Island [September 1907; Idjwi (Ijwi) Island, Lake Kivu, Democratic Republic of the Congo] and reached "Kissenji" [September 1907; Gisenyi on the northeast shore of Lake Kivu, close to the border of Democratic Republic of the Congo, Rwanda]. From there they went to Rutschurru [December 1907, Rutshuru, North Kivu Province, Democratic Republic of the Congo] and further north to Vitshumbi [December 1907] at the southern tip of Lake Edward. The expedition continued further along the west coast of Lake Albert to reach the Rwenzori Mountains via Kasindi [January 1908]. From Fort Beni [January to February 1908] on the western slopes of the Rwenzori Mountains the expedition went to Kassenje [March 1908] on the southwestern shore of Lake Albert. From here, the expedition turned west. Via Mawambi [April 1908] on the Ituri River and Avakubi [April 1908], it went along the left bank of the Aruwimi River to Basoko [May 1908; Tshopo Province, Democratic Republic of Congo] to the confluence with the Congo River, where the expedition ended in June 1908 (Schubotz 1909, 1912; Bamps 1975). The extensive zoological-botanical collections made during this expedition, including nearly 3000 vertebrates, were deposited at the $\mathrm{ZMB}$ and the Botanical Museum in Berlin. Most of the herpetological results of the expedition were published by Nieden (1913, Amphibia) and Sternfeld (1913, Reptilia).

From 1909 to 1910 a second "Deutsche Zentral-Afrika-Expedition", also under the leadership of Adolf Friedrich, Duke of Mecklenburg, extended along a main route from Cameroon via Spanish Guinea [Equatorial Guinea], Gabon, the Congo and the Ubangi River up to Fort de Possel [Possel, Central African Republic], and from there further north to Lake Chad and back via North Cameroon to the Niger Delta. Schubotz, who accompanied this expedition, deviated along the Ubangi River eastwards, in order to follow the White Nile in southern Sudan and returned via Khartoum and Egypt to Germany (Mecklenburg 1921). 
Hyperolius adspersus Peters, 1877a: 619, pl., fig. 6.

Holotype. ZMB 9176, "Chinchoxo (Westafrika)“ [Cabinda Province, Angola], don. Africanische Gesellschaft.

Present name. Hyperolius adspersus Peters, 1877a.

Remarks. The "Africanische Gesellschaft", or formally "Deutsche Gesellschaft zur Erforschung Aequatorial-Africas", sponsored the "Loango-Expedition" from 1873-1876 under the leadership of the German geographer and explorer Richard Paul Wilhelm Güssfeldt. The expedition had the task to establish a station at the Loango coast (at Chinchoxo), which was to serve as a depot for the material collected during the expedition. Geographic-topographical explorations into the interior of the African continent were also intended to be carried out. With an interdisciplinary research team, comprising the medical officer and zoologist Julius Falkenstein, the geographer Eduard Pechuël-Loesche, the geodesist von Görschen, Reserve Lieutenant Hans von Hattorf, the mechanic Otto Lindner, the botanist Herman Soyaux, and the topographer Major Alexander von Mechow, Güssfeld travelled for two years, starting in July 1873. They mainly followed the coastal area of Cabinda, on the Kouilo river, the Chiluango river, and on the lower course of the Nyanga river. From March 1874, they turned to Luanda, on the Cuango to Dondo and to the rapids of Cambambe, as well as to Quicombo and Novo Redondo (Güssfeldt et al. 1879, Weidmann 1894, Heintze 2007, Marques et al. 2018). The amphibians and reptiles collected during these trips were sent to ZMB and described by Peters $(1877 \mathrm{a}, \mathrm{b})$.

\section{Hyperolius albifrons Ahl, 1931a: 81.}

Holotype. ZMB 36095, “Afrika (ohne genaueren Fundort [without precise locality])", collector and/or donor unknown.

Present name. Hyperolius marmoratus Rapp, 1842.

Remarks. Drawing in Ahl (1931b: 355, fig. 230).

\section{Hyperolius albofrenatus Ahl, 1931a: 53.}

Holotype. ZMB 86012, "Deutsch-Ost-Afrika (genauerer Fundort unbekannt [without precise locality])" [probably Tanzania], coll. Ule, 22.XI.1912.

Present name. Hyperolius albofrenatus Ahl, 1931a.

Remarks. Drawing in Ahl (1931b: 315, fig. 189). There remains confusion about the collector and, related to this, the likely place of collection. A man by the name of Ernst Heinrich Georg Ule collected in Brazil and donated two frogs to the herpetological collection, one with the accession catalogue number C-581 (from November/ December 1912) without further data, and a second one (C-145) on 21 May 1904, collected on the Upper Amazon. The frog thus might actually be a South American tree frog and not a hyperoliid. However, another person named Dr. Ferdinand Uhl was a member of the "Deutsche Schutztruppe" in East Africa who collected the holotype of Hyperolius guttolineatus Ahl, 1931 (see below, unlo- cated type specimens). Lastly, a person with the surname Uhle collected in Sumatra, Bolivia and Argentina. Thus, neither the identity of the frog, nor its geographic origin and collector can be determined with certainty.

\section{Hyperolius albolabris Ahl, 1931a: 33.}

Holotype. ZMB 58748, "Kwa Buosch oder Bnorch (Deutsch-Ost-Afrika)", located in "Kwa Buosch in Süd Kavirondo" [near Lake Victoria, Migori district, southwestern Kenya] according to Neumann (1898: 242), coll. Oscar Rudolph Neumann, 26.II.1894.

Present name. Hyperolius glandicolor Peters, 1878.

Remarks. Depicted in Ahl (1931b: 288, fig. 161).

\section{Hyperolius alticola Ahl, 1931a: 106.}

Lectotype. ZMB 39008, "Ruwenzori, $1800 \mathrm{~m}$ hoch" [Rwenzori Mountains, Democratic Republic of the Congo], collected during the first "Deutsche Zentral-AfrikaExpedition", II/1908.

Paralectotype. ZMB 74944, same collecting data as for the lectotype.

Present name. Hyperolius discodactylus Ahl, 1931a.

Remarks. Depicted in Ahl (1931b: 380, fig. 255). Lectotype designation by Liedtke et al. (2014) who rediscovered the type specimens in the ZMB collection.

\section{Hyperolius angolensis}

see Hyperolius decorates, Hyperolius insignis, Hyperolius nossibeensis, Hyperolius vermiculatus.

\section{Hyperolius argentophthalmus Ahl, 1931a: 83.}

Holotype. ZMB 36092, “ohne genauen Fundort” [without specified locality], collector or donor unknown.

Present name. Hyperolius concolor (Hallowell, 1844).

Remarks. Depicted in Ahl (1931b: 357, fig. 233).

\section{Hyperolius argentovittis Ahl, 1931a: 72.}

Holotype. ZMB 85718, “Ujiji (Udjidji, Tanganyika-See, Deutsch-Ost-Afrika)" [Ujiji, Kigoma Province, Tanzania], coll. Paul Hösemann (Fig. 5).

Present name. Hyperolius marginatus Peters, 1854.

Remarks. Drawing in Ahl (1931b: 346, fig. 220).

Dr. Hösemann served in the colonial German Schutztruppe as medical officer [Stabsarzt], undertook anthropological studies, and between 1897 and 1907, collected zoological objects on the northeastern shore of Lake Tanganyika (Udjidji), in the Kissaka Region (southeast of Lake Mugesera, Ngoma and Kirehe Districts, Eastern Province, Rwanda] and between Mwanza and Moshi [northern Tanzania] (Hösemann 1897, Hafeneder 2010). Among others, he participated in the "German-French 


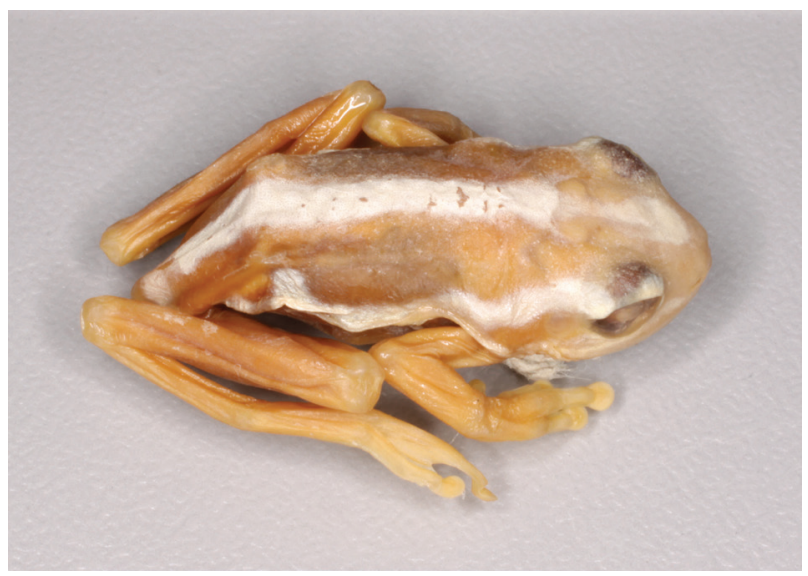

Figure 5. Holotype of Hyperolius argentovittis Ahl, 1931a, ZMB 85718 from "Ujiji (Udjidji, Tanganyika-See, Deutsch-Ost-Afrika)", coll. Hösemann.

Border Expedition" (October 1901 to December 1902) to define the southern border of Cameroon, during which he mapped the area from the camp Nyengwe, south of Kampo, to the Ngoko station in the Sanga Ngoko area (Danckelmann 1901; Fitzner 1901).

\section{Hyperolius argus Peters, 1854: 628.}

Syntypes. ZMB 4807 (two specimens according to Peters $1882 \mathrm{~b}$ and ZMB inventory catalogue), "Boror" [Companhia do Boror, Zambezia Province, Mozambique], coll. Wilhelm Carl Hartwig Peters.

Present name. Hyperolius argus Peters, 1854.

Remarks. Peters (1882b: 165) refers to two syntypes which he found in March 1846 in a bush at the edge of the forest near Boror. Depicted in Peters (1882b, pl. 22, fig. 6) and mentioned and depicted by Tornier (1896: 146, pl. 4, fig. 72 [=ZMB 4807]). Only one syntype could be located.

\section{Hyperolius argus \\ see Hyperolius flavoviridis, Hyperolius tettensis.}

\section{Hyperolius asper Ahl, 1931a: 49.}

Holotype. ZMB 36106, "Nairobi” [Kenya], coll. Felice Thomas.

Present name. Hyperolius marmoratus Rapp, 1842.

Remarks. Between 1896 and 1903 the engineer and transport officer of the "Mombasa-Uganda Railway" in British East Africa, Felice (sometimes Felix) Thomas sent several shipments, containing amphibians and reptiles, from the Kenyan coast province (Mombasa and Takanugu) and from Nairobi to ZMB.

\section{Hyperolius baumanni Ahl, 1931a: 34.}

Syntypes. ZMB 84956, coll. 26.VII.1894, ZMB 9092590926, coll. 07.V.1894, all from "Misahöhe, Togo" [Mis- sahomé, Agou Prefecture, Plateau Region, Togo], all coll. Ernst Richard Reinhold Baumann.

Present name. Hyperolius baumanni Ahl, 1931a.

Remarks. Drawing in Ahl (1931b: 291, fig. 167). According to Ahl (1831a: 35$)$ the original series consisted of four specimens, i.e. one collected on 26 July 1894 and three on 07 May 1893. However, the latter year given by Ahl is most probably a typographical error. According to Baumann's preserved original field label, the date of collection was the "7. Mai 1894". Another paratype MCZ A-17627 from "Misahöhe, Togo", coll. Baumann on 07 May 1894, was sent in exchange from ZMB in 1932 (Barbour and Loveridge 1946: 127). The latter specimen was erroneously regarded as a holotype by Seniagbeto et al. (2007: 77).

The natural scientist and cartographer Baumann joined the German Colonial Service in 1893. He worked at Klein Popo [Aného, Lacs Prefecture, Maritime Region, Togo] and was later stationed at Misahöhe [Agou Prefecture, Plateau Region, Togo] where he was deputy station chief from 1894-95. In November 1894, he accompanied the "Togo-Hinterland-Expedition" headed by the colonial officer Hans Gruner along the Volta River to Kete Kratschi [Kete Krachi, Oti Region, Ghana] and returned to Misahöhe. In the hinterland of the station (Agome Region) he collected zoological, botanical and ethnological objects, which were given to the museums in Berlin. In 1895 he returned to Germany where he died on 4 September as a result of malaria that he contracted on his return journey (Danckelmann 1895; Reichenow 1897; Heß 1902; Hafeneder 2008).

\section{Hyperolius bicolor}

see unlocated type specimens'.

\section{Hyperolius bitaeniatus Ahl, 1931a: 58.}

Holotype. ZMB 39004, "Konde-Nika, Deutsch-Ost-Afrika" [Region at the northern tip of Lake Malawi, Mbeya and Njombe Region, Tanzania], coll. Friedrich Georg Hans Heinrich Fülleborn.

Paratypes. ZMB 11919, "Deutsch-Ost-Afrika", coll. Oscar Rudolph Neumann and ZMB 85835-85840, "Konde-Nika", coll. Friedrich Georg Hans Heinrich Fülleborn.

Present name. Hyperolius mariae Barbour \& Loveridge, 1928.

Remarks. Drawing in Ahl (1931b: 322, fig. 196). Another paratype MCZ A-17628 from "Konde-Nika", coll. Fülleborn was sent in exchange from $\mathrm{ZMB}$ to $\mathrm{MCZ}$ in 1932 (Barbour and Loveridge 1946: 127).

\section{Hyperolius bivittatus Peters, 1854: 627.}

Syntypes. ZMB 4529 and ZMB 52503-52509 (formerly part of ZMB 4529), "Boror" [Companhia do Boror, Zambezia Province, Mozambique], coll. Wilhelm Carl Hartwig Peters. 
Present name. Afrixalus fornasini (Bianconi, 1849).

Remarks. Depicted in Peters (1882b, pl. 24, fig. 2 and pl. 26, fig. 6, sternum). Peters (1882b: 161) specified that he found this species in March 1846, often in grass and on bushes in the Prazo [estate] Boror northwest of Quellimane. Poynton and Broadley (1987: 192) incorrectly state that the description of $H$. bivittatus is based on a holotype.

\section{Hyperolius brachiofasciatus Ahl, 1931a: 87.}

Holotype. ZMB 77723, "Ngoto, Lobaje-Gebiet, Westafrika" [Lobaye Prefecture, Central African Republic]", coll. Günther Theodor Tessmann.

Present name. Hyperolius brachiofasciatus Ahl, 1931a.

Remarks. Depicted in Ahl (1931b: 361, fig. 237).

\section{Hyperolius breviceps Ahl, 1931a: 54.}

Holotype. ZMB 86026, "Tschimbo, Port. Ost-Afrika" [Chemba, Sofala Province, Upper Zambezi, Mozambique], coll. Wilhelm Tiesler, 11.XI.1905.

Paratypes. ZMB 39012 and ZMB 77753-77754 (formerly part of ZMB 39012), all from "Eldama River Station, südöstlich vom Baringo-See, Britisch-Ost-Afrika” [Eldama Ravine, Baringo County, Kenya], all coll. Hermann Grote.

Present name. Hyperolius marmoratus Rapp, 1842.

Remarks. Depicted in Ahl (1931b: 316, fig. 190). Another paratype, MCZ A-17629 from "Eldama River Station", coll. Grote was sent in exchange from ZMB in 1932 (Barbour and Loveridge 1946: 127).

In October 1905 and November 1907, Tiesler sent two shipments, including nearly 300 amphibians and reptiles, to ZMB. This material was collected between November 1904 and January 1906 in Portuguese East Africa [Mozambique] and described by Nieden (1915). The vouchers of this collection originated from the following localities: Cabayra, Chifumbazi, Chinta, Costa, Lukunga, Marazi, Missala, Tschimbo, Tschinoupe and from the Zambezi River without any exact locality data.

\section{Hyperolius brevipalmatus Ahl, 1931a: 25.}

Holotype. ZMB 24499, "Sangmelina, Süd Kamerun" [Sangmélina, Lobo Division, South Province, Cameroon], purch. Franz Hermann Rolle.

Present name. Afrixalus brevipalmatus Ahl, 1931a.

Remarks. Drawing in Ahl (1931b: 279, fig. 150). Perret (1976b: 21) listed two specimens, i.e. ZMB 24499 and ZMB 20132, as syntypes of $H$. brevipalmatus Ahl. However, Ahl's description is clearly based on a single specimen "1 Stück [piece]" from "Sangmelina" purchased from "Rolle". Furthermore, the collection data of ZMB 20132 from "Bipindi" [Bipindi village, Océan Department, South Province, Cameroon], coll. Georg Au- gust Zenker, do not match the information provided in the original description.

Rolle was a well-known dealer of zoological and enthnological objects. He maintained a worldwide network of collectors and suppliers and acquired several important collections. From 1889 onwards, he supplied private collectors as well as important European museums with zoological objects from Berlin. In later years, he traded objects under the name of the natural history institute "Kosmos".

Hyperolius buchholzi see "unlocated type specimens".

Hyperolius callichromus Ahl, 1931a: 99.

Holotype. ZMB 78576, "Westliches Russisi-Ufer und Nordwest-Ufer des Tanganyika" [West Bank of Ruzizi River, Democratic Republic of the Congo], coll. Rudolf Grauer (Fig. 6).

Paratypes. ZMB 78577-78583, same data as for the holotype, ZMB 85841-85844 "Usumbura" [Bujumbura, Bujumbura Mairie Province, Burundi], coll. Rudolf Grauer; ZMB 85854 "Kililana" [opposite of Manda Island, Lamu District, Coast Province, Kenya], coll. Clemens Andreas Denhard; ZMB 86000, "Kawende" [region in south Kigoma and northwest Katawi Division, eastern Tanzania], coll. Robert Reichert; ZMB 85869-85872, "Dar-esSalaam" [Dar es Salaam, Tanzania], collector unknown.

Present name. Hyperolius marginatus Peters, 1854.

Remarks. Drawings illustrating the variation of this taxon are given by Ahl (1931b: 373, fig. 248). Ahl (1931a: 101) mentioned 27 specimens, of which we could not locate the material collected by Schubotz and Paulus in "Bagamojo" and "Zentral Afrika". Two paratypes, MCZ A-17630 17631 from "Westliches Russisi-Ufer und Nordwest-Ufer des Tanganyika", coll. Grauer, were sent in exchange from ZMB in 1932 (Barbour and Loveridge 1946: 126).

The Austrian hunter and Africa explorer Grauer undertook several expeditions to Eastern Africa, e.g. to British East Africa [Uganda] (February to May 1904 and September to November 1905) and to Tanganyika in 1907, where he met the first "Deutsche Zentral-Afrika-Expedition" at Lake Kivu in August. Upon this meeting he handed the zoological material he had collected in the "Zwischenseengebiet" [Region between Lake Victoria, Lake Kivu and Lake Malawi, Tanzania] for ZMB and the Walter Rothschild Zoological Museum (now the Natural History Museum at Tring), to the German expedition. Grauer then turned south, travelled along the west bank of Lake Tanganyika and returned to Europe in early 1909 (Schubotz 1909, 1912; ÖAW 1959; Riedl-Dorn 2001). In November 1909, he returned to Africa, on behalf of the Natural History Museum Vienna (NMW) and travelled to Lake Victoria and Lake Malawi. From there he turned further north along the African Rift Valley to Beni [North Kivu Province, Democratic Republic of the Congo], from where he returned to Austria in May 1911. About 250 herpetological objects (mainly reptiles) collected during 


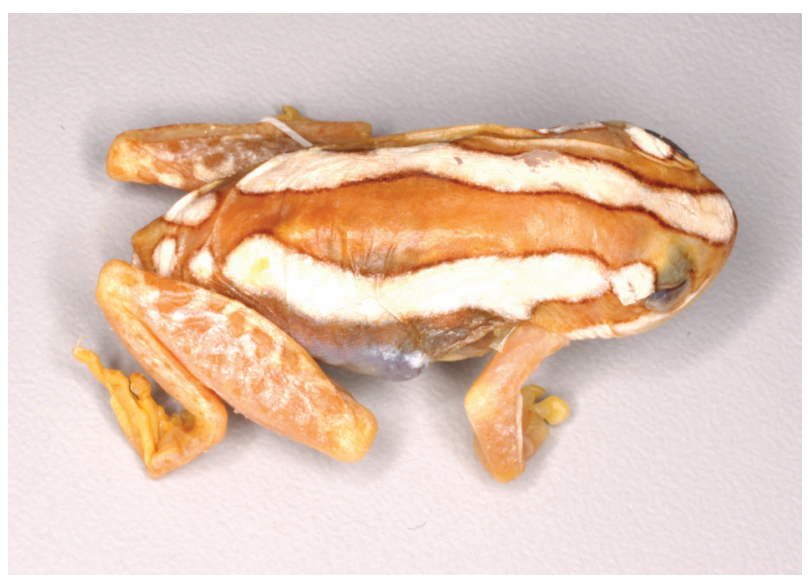

Figure 6. Holotype of Hyperolius callichromus Ahl, 1931a, ZMB 78576 from "Westliches Russisi-Ufer", coll. Grauer.

this expedition are in the collection of NMW, collected mainly in South Kivu, North Kivu and Orientale Province of D. R. Congo (Silke Schweiger in litt. 5 August 2020). The herpetological collections of Grauer's last expedition were partly described by Steindachner (1911) and Werner (1924). We refer also to Gemel et al. (2019) for information about the type material collected by Grauer and deposited in the NMW collection.

\section{Hyperolius castaneus Ahl, 1931a: 31.}

Holotype. ZMB 60230, "Vulkangebiet nord-östlich des Kivu-See's" [volcano region northeast of Lake Kivu, Virunga Mountains, along the border between Rwanda and the Democratic Republic of the Congo], coll. Werner Alborus von Raven, X/1907.

Present name. Hyperolius castaneus Ahl, 1931.

Remarks. Drawing in Ahl (1931b: 286, fig. 159). The German medical doctor von Raven, who specialized in bacteriology and tropical medicine, accompanied the first "Deutsche Zentral-Afrika-Expedition" under the leadership of Adolf Friedrich, Duke of Mecklenburg from 1907 to 1908 (Schubotz 1909). For expedition information see account on Hyperolius adolphi-friederici.

\section{Hyperolius castaneus}

see Hyperolius adolphi-friederici, Hyperolius latifrons, Hyperolius rugegensis, Hyperolius ventrimaculatus.

\section{Hyperolius chabanaudi Ahl, 1931a: 124.}

Holotype. ZMB 18228, "Beniló, Französischer Kongo" [Benito River, Equatorial Guinea], don. William Frederic Henry Rosenberg.

Present name. Hyperolius phantasticus (Boulenger, 1899).

Remarks. The English ornithologist and entomologist Rosenberg collected mainly for the British Museum of
Natural History (Günther 1906). In the accession catalogues of the herpetological department at $\mathrm{ZMB}$, it is documented that Rosenberg on multiple occasions sent amphibians and reptiles to ZMB between 1900 and 1925. These vouchers were collected in Columbia, Peru, Ecuador, Venezuela, Cameroon, and Equatorial Guinea.

\section{Hyperolius coeruleopunctatus Ahl, 1931a: 76.}

Holotype. ZMB 36115, "Nairobi” [Kenya], coll. Felice Thomas.

Paratypes. ZMB 77540-77542, "Nairobi", coll. F. Thomas and ZMB 85884 "Kibwezi" [Makueni County, Kenya], coll. Georg R. O. Scheffler.

Present name. Hyperolius glandicolor Peters, 1878.

Remarks. Depicted in Ahl (1931b: 351, fig. 225).

\section{Hyperolius concolor}

see Hyperolius argentophthalmus, Hyperolius depressus, Hyperolius guineensis, Hyperolius moseri (unlocated type specimens), Hyperolius narinus, $\mathrm{Hy}$ perolius petersi, Hyperolius togoensis.

Hyperolius concolor guttatus see Hyperolius guttatus, Hyperolius hildebrandti, Hyperolius maximus, Hyperolius pulcher.

\section{Hyperolius decipiens Ahl, 1931a: 120.}

Syntypes. ZMB 39003 and ZMB 77763-77765 (formerly part of ZMB 39003), "Westliches Russisi-Ufer und Nordwest-Ufer des Tanganyika" [West Bank of Ruzizi River and northwest bank of Lake Tanganyika, Democratic Republic of the Congo], coll. Rudolf Grauer 1908-1911.

Present name. Hyperolius marginatus Peters, 1854.

Remarks. Depicted in Ahl (1931b: 405, fig. 280). Another paratype, MCZ A-17633 from "Westliches Russisi-Ufer und Nordwest-Ufer des Tanganyika", coll. Grauer, was sent to MCZ in exchange in 1932 (Barbour and Loveridge 1946: 126).

\section{Hyperolius decoratus Ahl, 1931a: 78.}

Lectotype. ZMB 36112, "Longa" [Longa River, Angola], coll. Ludwig J. Brühl or Otto Gleim.

Paralectotypes. ZMB 31905-31906, "Angola", coll. Brühl; ZMB 38255 and ZMB 77797 (formerly part of ZMB 38255), "Longa, Angola", coll. Brühl or Gleim; ZMB 77752, “Angola” coll. Gleim.

Present name. Hyperolius angolensis Steindachner, 1867 (fide Marques et al. 2018).

Remarks. Lectotype designation by Perret (1962). Another paralectotype MCZ A-17632 from "Longa", coll. Brühl and Gleim, was sent in exchange from ZMB 
in 1932 (Barbour and Loveridge 1946: 127). Drawing in Ahl (1931b: 352, fig. 227). Ahl (1931a: 80) stated that seven specimens were collected by "Brühl and Gleim". However, these two people were not active in Angola at the same time (see below). It is possible that specimens of both collectors were stored together. Thus, it is no longer possible to assign the specimens to one collector.

Gleim was Deputy Governor of the German Colony of Togo from 1896 to 1898. From 1899, he was sent to São Paolo de Loanda by the "Kolonialabteilung des Auswärtigen Amtes", where he served as the first professional consul for Angola and French Congo. From 1910 to 1911 he was Governor of Cameroon (Schnee 1920a). On his return from Angola to Germany in 1901, he donated various collections of vertebrates and invertebrates to ZMB. In 1928 Prof. Dr. Brühl, at that time custodian at the Institut für Meereskunde Berlin, donated the insects and vertebrates he collected in Mossamedes (Angola) from 1922 to 1923 to $\mathrm{ZMB}$.

\section{Hyperolius depressus Ahl, 1931a: 61.}

Holotype. ZMB 43554, "Misahöhe, Togo" [Missahomé, Agou Prefecture, Plateau Region, Togo], coll. Ernst Richard Reinhold Baumann.

Present name. Hyperolius concolor (Hallowell, 1844).

Remarks. Depicted in Ahl (1931b: 326, fig. 200).

\section{Hyperolius dermatus Ahl, 1931a: 108.}

Holotype. ZMB 85999, "Cabayra (Port. Ost-Afrika)" [? Cabaíra, Cahora Bassa District, Tete Province, Mozambique], coll. Wilhelm Tiesler, 20.VII.1905.

Present name. Hyperolius marmoratus Rapp, 1842.

Remarks. Ahl (1931a: 109) incorrectly names "Teisler" as collector. The exact position of the type locality remain dubious. There is also a Cabaia in the Zambézia province, district of Namacurra, area of Macuze, but it is unclear if this locality was intended.

\section{Hyperolius dintelmanni Lötters \& Schmitz, 2004: 150.}

Paratype. ZMB 79543, “Edib Hills (ca. 1,200 m above sea level) Bakossi Mountain, Southwest Cameroon (457'N, 9³9'E)" [type locality], coll. Oliver Euskirchen and Andreas Schmitz, 03.XII.1997.

Present status. Hyperolius dintelmanni Lötters \& Schmitz, 2004.

Remarks. Holotype ZFMK 67871 and ten paratypes ZFMK 67441, 67443-447, ZFMK 67453, ZFMK 6787267873 and ZFMK 67890 all from the type locality. ZMB 79543 (formerly ZFMK 67442), was given in exchange to ZMB on 18.X.2013 (see also Böhme 2014).

\section{Hyperolius discodactylus Ahl, 1931a: 89.}

Holotype. ZMB 36089, "Rugegewald" [Nyungwe Forest, Cyangugu Prefecture, West Province, Rwanda], coll. Rudolf Grauer.

Present name. Hyperolius discodactylus Ahl, 1931.

Remarks. Drawing in Ahl (1931b: 364, fig. 239). According to Ahl (1931a: 90) the original series consists of seven specimens from "Rugegewald", including the "Type" and from "westlich des Albert-Edward-Sees's" [west of Lake Edward, Democratic Republic of the Congo], all coll. Grauer. A paratype MCZ A-17634 from Lake Edward, coll. Grauer was sent in exchange to $\mathrm{MCZ}$ in 1932 (Barbour and Loveridge 1946: 128). The remaining five paratypes could not be located. Liedtke et al. (2014) regarded ZMB 36089 as lectotype and restricted the type locality to "Nyungwe Forest (most likely Rwasenkoko [Uwasenkoko])".

\section{Hyperolius discodactylus see Hyperolius alticola.}

Hyperolius dorsalis Peters, 1875: 206, pl. 1, fig. 2.

Syntypes. ZMB 4488, "Boutry" [Butre (Bootry), Ahanta West District, Western Region, Ghana], don. Hermann Schlegel (Museum Leyden), and ZMB 8850 "Victoria" [Limbe, Fako Division, Southwest Region, Cameroon], coll. Ernst Richard Reinhold Baumann.

Present name. Afrixalus dorsalis (Peters, 1875).

Remarks. Peters' (1875) description was based on an unknown number of syntypes. He mentioned several specimens found in a pond in Victoria of which we could locate only one specimen. Mertens (1938) restricted the type locality to "Boutry".

\section{Hyperolius fimbriolatus Buchholz \& Peters in Peters, 1876: 121.}

Syntypes. ZMB 8830 and ZMB 65178 (formerly part of ZMB 8830), "Limbareni am Ogowe" [Lambaréné on the river Ogooué (or Ogowe), Moyen-Ogooué Province, Gabon], coll. Reinhold Wilhelm Buchholz.

Present name. Hyperolius olivaceus Peters, 1876.

Remarks. Depicted in Tornier (1896, pl. 4, fig. 100 and 101) and partly redrawn in Ahl (1931b: 332, fig. 205).

The name Rappia fimbriata Tornier (1896: 153, pl. 4, figs 100, 101) is categorized as nomen inquirendum, "Name(s) unassigned to a living or extinct population" by Frost (2021). Tornier (1896) attributed the authorship of this name to "B e P" which refer to Buchholz and Peters instead of "Duméril and Bibron" as claimed by Frost (2021). Tornier (1.c.) mentioned the type material as collected at "Gowe Limbareni", a writing error for "Limbareni am Ogowe [river]" (Peters 1876). However, Buchholz and Peters never together described a reed frog with 
the specific epithet "fimbriata". Tornier's name fimbriata does not meet the requirements of Art. 33.2 of the 'Code' (ICZN 1999) for an "emendation". We therefore consider fimbriata Tornier, 1896 as an incorrect subsequent spelling of the specific epithet fimbriolata Buchholz \& Peters in Peters, 1876.

\section{Hyperolius flavoguttatus Ahl, 1931a: 96.}

Holotype. ZMB 39011, "Bukoba" [Bukoba Urban District, Kagera Region, Tanzania], coll. Franz Ludwig Stuhlmann.

Paratypes. ZMB 75607 (formerly part of ZMB 39011), from "Bukoba", coll. Stuhlmann and ZMB 85757, "Kenia”, coll. Johann Georg Kolb, 1894.

Present name. Hyperolius viridiflavus (Duméril \& Bibron, 1841).

Remarks. Depicted in Tornier (1896: 136, fig. 1) and redrawn in Ahl (1931b: 370, fig. 245). According to Ahl (1931a: 97) the original series consists of five specimens from "Bukoba", including the "Type" and from "Kenia", collected by Stuhlmann and Kolb. Another paratype MCZ A-17635 from "Bukoba", coll. Stuhlmann, was sent to MCZ in exchange in 1932 (Barbour and Loveridge 1946: 128). The fourth paratype could not be located.

The German zoologist, cartographer, explorer and colonial official Stuhlmann spent a total of 14 years in East Africa. With the financial support of the Akademie der Wissenschaften [Academy of Sciences] zu Berlin, he investigated the coastal regions of Zanzibar and the adjacent mainland including "Usegúa" and "Ungúu" in present-day Tanzania in the summer of 1888; then, until mid-1889, the area of the Zambezi estuary around Quelimane in Mozambique. From April 1890 to 1892 , Stuhlmann participated as a scientist, together with Lieutenant Wilhelm Langheld, on the expedition of Mehmed Emin Pasha [also known as Eduard Karl Oskar Theodor Schnitzer] to the German East African colonial area. The expedition led them from Bagamoyo (26 April 1890) via Tabora (29 July) to Bukoba on Lake Victoria (November 1890). From here, Stuhlmann undertook a trip on Lake Victoria to Murchison Bay in Uganda (December 1890) and reached Mengo Mountain (26 to 29 December) via Manjongo [Rubaga Division, Kampala District, Central Region, Uganda]. After his return to Bukoba, he set off (12 February 1891) towards the west in the Karagwe Region, and after crossing the Kagera River (06 April 1891), the expedition reached the southwestern tip of Lake Edward in early May 1891. The expedition turned west of Lake Edward another $250 \mathrm{~km}$ to the north, but was terminated in mid-September 1891 due to insurmountable difficulties. With a group of 27 askaris (local soldiers serving in European colonial armies) and 100 porters Stuhlmann went back to Bukoba, where he arrived on 17 March 1891. Emin Pasha, in contrast decided to stay behind with sick expedition members, turned southwest towards the Congo River and was murdered by Arab slave traders $80 \mathrm{~km}$ from this destination at Kinene on Mwiko River on 20 October 1892. Stuhlmann's herpetological collections from these expeditions were sent to Johann Georg Pfeffer at the Zoologische Museum Hamburg, who published the first results (Pfeffer 1889, 1893). Parts of these collections, including "Doubletten" [doublets], were later donated to ZMB (Stuhlmann 1893; Tornier 1896). In July 1892 Stuhlmann returned to Bagamoyo on the East African coast, where he engaged in cartography and other scientific activities in Dar-es-Salaam and its surroundings until 1901. Between December 1900 and June 1901 Stuhlmann visited India, Sri Lanka, Singapore, and Indonesia. After returning to Africa, he was offered the post of the director of the "Biologisch-Landwirtschaftliche Institut Amani" [Agro-biological Institute Amani] in Usambara in July 1901, a post he took up in June 1903 and held until the end of 1905. During his last stay in Africa from December 1906 to January 1908, he worked in Amani primarily on the completion of his "Kulturgeschichte von Ostafrika" [Cultural history of East Africa] published in 1909. After various tropical diseases, he left the African continent at the age of 43 years with his health "exhausted" on 27 January 1908, and returned to Germany (Stuhlmann 1891, 1893, 1894, 1909; Danckelmann 1891, 1892; Weidmann 1894; Schnee 1920b; Bindseil 2008; Schabel 1990; Wenzel Geißler et al. 2020).

\section{Hyperolius flavoviridis Peters, 1854: 628.}

Holotype. ZMB 6631, "Boror" [Companhia do Boror, Zambezia Province, Mozambique], coll. Wilhelm Carl Hartwig Peters.

Present name. Hyperolius argus Peters, 1854.

Remarks. Depicted in Peters (1882b, pl. 22, fig. 4). Bauer et al. (1995: 44) regarded two specimens, i.e. ZMB 6631 and ZMB 6632 as syntypes of $H$. flavoviridis. However, Peters (1854: 628) mentioned only material from "Boror" in his original description and he specified later (1882b: 164) that he got only one male from that locality, which corresponds to ZMB 6631. Although ZMB 6632 from "Halbinsel Cabaceira" [Peninsula Cabaceira, Mossuril District, Nampula Province, Mozambique], collected in June 1843, is marked by Peters' hand as type of $H$. flavoviridis in the ZMB inventory catalogues, the stated locality does not correspond with the type locality. Another two specimens from "Tette" donated from ZMB to the collection in Leiden (RMNH RENA-1780 and 1785) have been regarded as possible syntypes of $H$. flavoviridis (Bauer et al. 1995: 44, Gassó Miracle et al. 2007: 36). Both specimens can be excluded as types of $H$. flavoviridis because of the locality information, being different from the type locality. Likewise they cannot be the types of $H$. tettensis because of the single female type specimen mentioned by Peters (1882b: 164) is ZMB 4812 (see below). 


\section{Hyperolius friedemanni Mercurio and Rödel in Channing, Hillers, Lötters, Rödel, Schick, Conradie, Rödder, Mercurio, Wagner, Dehling, Du Preez, Kielgast \& Burger, 2013: 20, fig. 4D, fig. 6, second row left.}

Paratype. ZMB 76095, "Karionga, Malawi, 955'59.6"S, 3356'44.6"N, $472 \mathrm{~m}$ a.s.1." [Karonga District, Northern Region, Malawi], coll. Vincenzo Mercurio, 07.II.2007.

Present name. Hyperolius friedemanni Mercurio and Rödel 2013.

Remarks. Holotype: SMF 85694 from "Karionga, Malawi, 955'59.6"S, 3356'44.6"N, 472 m a.s.l.”, coll. Mercurio, 07.II.2007 and additional paratypes: SAIAB 186000 (two juveniles) from "Monkey Bay, Malawi", collector not mentioned.

\section{Hyperolius friedrichsi Ahl, 1930d: 67.}

Holotype. ZMB 30637, “Antananarivo, Madagaskar” [Analamanga Region, Madagascar], coll. Karl Friedrichs [sic] aus Rostock.

Present name. Heterixalus betsileo (Grandidier, 1872).

Remarks. Depicted in Ahl (1931b: 422, fig. 295). From October 1914 until the end of 1915, the German zoologist and colonial officer Prof. Dr. Friederichs, who was a prisoner of war during the First World War, collected in the courtyard of the French Fort Duchesne (on a hill opposite of Antananarivo, ca. $1400 \mathrm{~m}$ a.s.1.). Later, he continued collecting until 1916 on Kap Diego [Cap Diego, Antsiranana I District, Diana Region, Diego Suarez Province] in northern Madagascar (Schultheß 1918; Friederichs 1919).

\section{Hyperolius fuelleborni Ahl, 1931a: 75.}

Syntypes. ZMB 71184-71186 and 85925-85927, "Neu Helgoland“ [Pugulo (or Papaya Island), a small rock island in Lake Malawi, Mbinga District, Ruvuma Region, Tanzania]; ZMB 77465-77468, 85919-85921, 85928, 85964-85971, 86138, 90972, “Langenburg” [Lumbira, Mbeya Region, Tanzania]; ZMB 85922-85924, "Langenburg - Nordende des Nyassa" [Lumbira at the northern shore of Lake Malawi]; ZMB 85972-85973, 90928, "Miramba bei Langenburg" [Miramba near Lumbira]; ZMB 85929-85963, 85974-85988, 86017, 86132-86137, 90929-90948, "Rugwe“" [Rungwe village, Mbeya Region, Tanzania]; ZMB 86128-86131, "S'ongwe" [Songwe, at the border to Malawi on the northwestern tip of Lake Malawi, Kyela District, South Mbeya Region, Tanzania]; ZMB 86126-86127 "D.O.A." [German East Africa], all coll. Friedrich Georg Hans Heinrich Fülleborn, 1897-1899 (Fülleborn 1900a, b) (Fig. 7).

Present name. Hyperolius marmoratus Rapp, 1842.

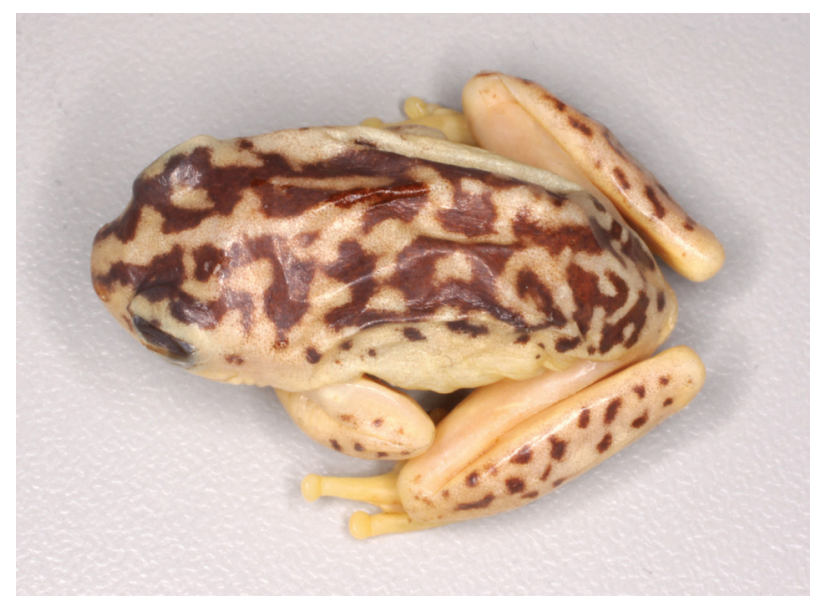

Figure 7. Syntype of Hyperolius fuelleborni Ahl, 1931a, ZMB 71186 from "Neu Helgoland" coll. Fülleborn.

Remarks. Two drawings showing the variation of this taxon are presented by Ahl (1931b: 349, fig. 224). According to Ahl (1931a: 76) 199 specimens were originally present. Two paratypes, MCZ A-17636-17637 from "Miramba bei Langenburg", coll. Fülleborn, were sent to MCZ in 1932 (Barbour and Loveridge 1946: 128).

\section{Hyperolius fusciventris Peters, 1876: 122.}

Syntypes. ZMB 6635, "Liberia", don. Stephen Allen Benson, and ZMB 8668, "Liberia", coll. Heinrich Wolfgang Ludwig Dohrn.

Present name. Hyperolius fusciventris Peters, 1876.

Remarks. Peters (1876: 122) explicitly mentions the inventory numbers for the two syntypes in ZMB. The Prussian zoologist H. Dohrn travelled between 1864 and 1866 in West Africa where he collected mainly vertebrates. He exchanged his duplicates with MSNG, NMW, RMNH and ZMB (Pfaffl 2017).

\section{Hyperolius fusciventris}

see Hyperolius oeseri, Hyperolius rosaceus, Hyperolius trifasciatus.

\section{Hyperolius glandicolor Peters, 1878: 209, pl. 2, fig. 9.}

Syntypes. ZMB 9299 and ZMB 77768 (formerly part of ZMB 9299), "Taita" [Taita Hills, Taita-Taveta County, Kenya], coll. Johann Maria Hildebrandt.

Present name. Hyperolius glandicolor Peters, 1878.

Remarks. Depicted in Ahl (1831b: 345, fig. 219), reprinted from Peters (1878).

In March 1872, Hildebrandt travelled from Berlin via Egypt to the southwest coast of the Arabian Peninsula and to Aden, where he stayed until the end of 1872. In spring 1873, he went from Zanzibar to Karachi and travelled the Indus upwards. After returning to Zanzibar in July 1873, he travelled the Wami and Kingani (Rufu) 
Rivers in present-day Tanzania together with the animal trader and director of the Hamburg Zoo, Carl Gottfried Wilhelm Heinrich Hagenbeck, and then visited the southern Somali coast alone. He returned to Europe in August 1874.

In February 1875, Hildebrandt arrived again in Aden and visited the "Serrut Mountains" [Somaliland]. Then he went to Zanzibar and the Comoros (Johanna Island [Anjouan], June to September 1875). Back in Zanzibar he prepared his expedition into the Inner Africa, via Pangani [Tanzania], Lamu, through the South Gala countries up the Tana River. He had to return to Mombasa due to illness in December 1875. In November 1876 he started again from Zanzibar via Mombasa (10 January 1877) in the direction of Mount Kenya. He travelled the Taita, Ukamba and Kitui areas, but had to return to Mombasa without reaching his actual destination Mount Kenya, from which he was only a three days' march away. He arrived again in Mombasa in August 1877 (Kurtz 1877). The type material of $H$. glandicolor was collected from June to July 1877 during Hildebrandt's stay in the Taita region (Hildebrandt 1877).

\section{Hyperolius glandicolor}

see Hyperolius albolabris, Hyperolius coeruleopunctatus, Hyperolius goetzei, Hyperolius pulchromarmoratus, Hyperolius scheffleri, Hyperolius striolatus, Hyperolius bergeri (unlocated type specimen).

\section{Hyperolius goetzei Ahl, 1931a: 128.}

Holotype. ZMB 53181, "Uhehe" [Uhehe Highlands, Iringa Region, Tanzania], coll. Walter Goetze, 1899.

Paratype: ZMB 53182, "Massai-Nyika" [Massai Steppe, Tanzania], coll. Oscar Rudolph Neumann, 1893.

Present name. Hyperolius glandicolor Peters, 1878.

Remarks. Drawing in Ahl (1931b: 413, fig. 286). From 1898 to November 1899 the gardener and botanist Goetze travelled from Uhehe [Iringa Region] to Langenburg [Lumbira at the northern shore of Lake Malawi] and collected in the mountainous region between Lake Rukwa and Lake Malawi, particularly in the Kinga Mountains [Kipengere Range SW Tanzania] (Engler 1902; Urban 1917).

\section{Hyperolius granulosus Peters, 1867: 891, footnote.}

Syntypes. ZMB 4811 and ZMB 75652 (formerly part of ZMB 4811), "Mossambique", coll. Wilhelm Carl Hartwig Peters.

Present name. Hyperolius marmoratus Rapp, 1842.

Remarks. Peters (1882b: 162) specified the locality for the two syntypes as "Capanga am Flüsschen Mutizi östlich von Tette" [Capanga, Maravia District, Tete Province, Mozambique] where he collected on August 8, 1845. One of the specimens is depicted in Peters (1882b, pl. 22, fig. 3).
The name Rappia granulata Tornier (1896: 151) is categorized as nomen inquirendum, "Name(s) unassigned to a living or extinct population" by Frost (2021) who placed the type locality "Tette" mistakenly in Tanzania. Tornier (1896) attributed the authorship of this name to Peters and mentioned the type specimens by number (ZMB 4811). However, Peters never described a reed frog with the specific epithet "granulata". Tornier's name granulata does not meet the requirements of Art. 33.2 of the 'Code' (ICZN 1999) for an "emendation". We therefore consider granulata Tornier, 1896 as an incorrect subsequent spelling of the specific epithet granulosus Peters, 1867.

\section{Hyperolius graueri Ahl, 1931a: 131.}

Holotype. ZMB 85758, "Westliches Russisi-Ufer und Nordwestufer des Tanganyika-See's" [West Bank of Ruzizi River, Democratic Republic of the Congo and northwestern shore of Lake Tanganyika], coll. Rudolf Grauer 1908-1911.

Present name. Hyperolius marginatus Peters, 1854.

Remarks. Drawing in Ahl (1931b: 420, fig. 292).

\section{Hyperolius guineensis Ahl, 1931a: 30.}

Holotype. ZMB 77464, “Guinea”, don. Hermann Schlegel (Museum Leyden).

Present name. Hyperolius concolor (Hallowell, 1844).

Remarks. Drawing in Ahl (1931b: 285, fig. 158).

\section{Hyperolius gularis Ahl, 1931a: 125.}

Holotype. ZMB 83544, "Loanda" [Luanda, Angola], coll. Carl May.

Present name. Hyperolius gularis Ahl, 1931.

Remarks. Drawing in Ahl (1931b: 408, fig. 281).

First Lieutenant May collected between 1901 and 1903 in Luanda and surroundings, e.g. in Mubella near Funda on the Bengo River [Municipality of Cacuaco, Luanda Province, Angola] (Matschie 1906). He donated the collected zoological objects as gifts to ZMB from 1902 to 1903 (Anonymous 1903, 1904). Recently, the type was erroneously mentioned as probably lost by Marques et al. (2018).

\section{Hyperolius guttatus Peters, 1875: 207, pl. 2, fig. 3.}

Lectotype. ZMB 8378, "Cameruns” [Douala, Region Littoral, Cameroon], coll. Georg Anton Eugen Reichenow, don. Reinhold Wilhelm Buchholz.

Paralectotype. ZMB 4489. "Boutry" [Butre (Bootry), Ahanta West District, Western Region, Ghana], coll. Hendrik Severinus Pel, don. Hermann Schlegel (Museum Leiden).

Present name. Hyperolius concolor guttatus Peters, 1875, according to Frétey et al. (2014). 
Remarks. Lectotype by subsequent designation of Laurent (1961: 73). Frétey et al. (2014) corrected the type locality to "Douala" based on an account and a map of Buchholz’ Central African travels provided by Heinersdorff (1880). According to the latter, Buchholz visited "Cameroons" between October 1872 and August 1874. According to Frétey et al. (2014) the collection in RMNH holds four additional paralectotypes (RMNH RENA 1788 A-D) from "Boutry", coll. Pel (not listed by Gasso Miracle et al. 2007). Drawing in Ahl (1931b: 354, fig. 229) figuring paralectotype ZMB 4489. For the origin, history and status of Hyperolius guttatus and drawings, photographs and redescriptions of the ZMB type specimens we refer to the revision by Frétey et al. (2014).

The Berlin ornithologist Reichenow travelled together with Lühder and Buchholz from spring 1872 on a one year collecting trip to "Akkrá" on the Gold Coast [Accra, Ghana] and the region around "Camaroons" [Douala Region, Cameroon] (Reichenow 1874; Heinersdorf 1880; Weidmann 1894; Stresemann 1943; see also remarks on Hyperolius acutirostris). Reichenow was assistant in the fish and reptile department in ZMB until Wilhelm Peters' death. From 1883 he worked as an administrator and assistant in the mammal and reptile department. In 1888 he became curator for the reptile, bird and mammal exhibition in the new ZMB building on the Ivalidenstraße. After the retirement of his father-in-law Jean Louis Bennoit Cabanis in 1892 , and after almost twenty years conducting various activities at ZMB, Reichenow took over as the curator of the ornithological collection (Stresemann 1943).

\section{Hyperolius hieroglyphicus Ahl, 1931a: 126.}

Lectotype. ZMB 20793, "Bamenda, Kamerun" [Mezam Department, Northwest Region, Cameroon], coll. First Lieutenant Karl Moritz Ernst Gustav Wilhelm Adametz.

Paralectotypes. ZMB 20795, 77728 (formerly part of ZMB 20793), 77798-77801 (formerly part of ZMB 20795), coll. Adametz, 1909; ZMB 27270, 77756-77757 (formerly part of ZMB 22270), coll. Hans Glauning, XXI/1907; ZMB 22321, coll. Lieutenant Naumann, 1911; all specimens from "Bamenda". 1910).

Present name. Hyperolius riggenbachi (Nieden,

Remarks. Drawing in Ahl (1931b: 409, fig. 282) modified from Nieden (1910: 243, fig. 3). Lecotype designation by Laurent (1961: 76). Photograph of the lectotype in Perret (1962: 243, fig. 1). Another paratype MCZ A-17638 from "Bamenda", coll. Adametz, was sent to $\mathrm{MCZ}$ in exchange from ZMB in 1932 (Barbour and Loveridge 1946: 128).

\section{Hyperolius hildebrandti Ahl, 1931a: 64.}

Holotype. ZMB 8378, "Kamerun” [Douala, Region Littoral, Cameroon], coll. Georg Anton Eugen Reichenow, don. Reinhold Wilhelm Buchholz.
Present name. Hyperolius concolor guttatus Peters, 1875, according to Frétey et al. (2014).

Remarks. Depicted in Ahl (1931b: 334, fig. 207), copied from Peters (1875, pl. 2, fig. 3). The same specimen that is the holotype of $H$. hildebrandti is also the lectotype of $H$. guttatus Peters, 1875. For the origin, history and status as well as type localities, drawings, photographs and redescriptions of the ZMB types of $H$. guttatus and $H$. hildebrandti, we refer to the revision by Frétey et al. (2014).

\section{Hyperolius houyi Ahl, 1931: 101.}

Holotype. ZMB 39099, "SW-Ussagara (Neu-Kamerun)“ [partly in error, see remarks below], coll. Reinhardt Houy, 29.XI.1911.

Present name. Hyperolius houyi Ahl, 1931a.

Remarks. Depicted in Ahl (1931b: 374, fig. 249). The type locality indicated by Ahl (1931a: 102) is misleading and composed of two different regions which are far apart. Houy was a member of the "Lagone-Pama-Expedition 1912-13", which he accompanied as government doctor and zoologist to "Neu-Kamerun", and several natural history objects from this expedition were sent by him to ZMB. Together with the topographer and First Lieutenant Otto Tiller, he also accompanied the "Expedition ins Zwischenseengebiet in Ostafrika" [region between Lake Kivu and Lake Victoria] in 1911, the expedition directed by the colonial geographer Hans Heinrich Josef Meyer. According to the original label, the holotype of $H$. houyi was collected on 29 November 1911, at the end of Meyer's expedition to East Afrika (see also Urban 1917). On the basis of the map showing the expedition route (Meyer 1913), the corrected type locality for $H$. houyi has to be "SW-Ussagara" [southern Kilosa District, Morogoro Region, Tanzania].

\section{Hyperolius insignis Bocage, 1868: 844, fig. 2.}

Syntype. ZMB 6462, "Benguella" [Benguela, Angola], coll. José Alberto de Oliveira Anchieta, don. José Vicente Barbosa du Bocage.

Present name. Hyperolius angolensis Steindachner, 1867 (fide Marques et al. 2018).

Remarks. Drawing in Ahl (1931b: 284, fig. 157), copied from Bocage (1868: 844, fig. 2). The Berlin syntype was sent in 1869 in exchange from Lisbon by Bocage and was mentioned and depicted by Tornier (1896: 143, pl. 4, fig. 48). The syntypes MBL T. 21-164, 27-167 from "Benguella", coll. Anchieta and "St. Salvador du Congo" coll. António José de Sousa Barroso were destroyed by a fire in the Museu Bocage on 18 March 1978 (Marques et al. 2018: 90). Perret (1976a: 28) corrected the type locality to "São Salvador do Congo, Angola, and Novo Redondo, Angola". The Berlin syntype is not mentioned by Marques et al. (2018), but probably is the only remaining syntype. 
Hyperolius inyangae Channing in Channing, Hillers, Lötters, Rödel, Schick, Conradie, Rödder, Mercurio, Wagner, Dehling, Du Preez, Kielgast \& Burger, 2013: 322, fig. 6 second row right, fig. $12 \mathrm{C}$ and $D$.

Holotype. ZMB 77276, "Rhodes Dam in the Nyanga National Park, Zimbabwe, 18¹7'20.3"S, 3243'24.4"E”, coll. Alan Channing, 14.XI.2009.

Paratypes. ZMB 77277-77279, same collecting data as for the holotype.

Present name. Hyperolius inyangae Channing in Channing, Hillers, Lötters, Rödel, Schick, Conradie, Rödder, Mercurio, Wagner, Dehling, Du Preez, Kielgast \& Burger, 2013.

\section{Hyperolius ipianae Ahl, 1931a: 43.}

Holotype. ZMB 36091, "Ipiana” [Ipyana (Ipanya) on Kiwira River, at the northwestern tip of Lake Malawi, Kyela District, South Mbeya Region, Tanzania], coll. Adolf Ferdinand Stolz.

Present name. Hyperolius kivuensis Ahl, 1931a.

Remarks. Drawing in Ahl (1931b: 301, fig. 175). Stolz was a mission trader and planter, working as head of the missionary station of the Moravian Church (Herrnhuter Brüdergemeinde) at Ipyana from 1898 to1903. Afterwards, and until 1914, he collected botanical and zoological objects in Kiymbila and Rungwe (Urban 1917; Jones et al. 2000). Amphibians and reptiles from his collection arrived at ZMB on 8 June 1901.

\section{Hyperolius irregularis Ahl, 1931a: 114.}

Syntypes. ZMB 36105 and 75606 (formerly part of ZMB 36105), "Mohasi-See, Ruanda" [Lake Muhazi, Eastern Province, Rwanda], coll. Johann Gustav Hermann Schubotz, VII/1907.

Present name. Hyperolius viridiflavus (Duméril \& Bibron, 1841).

Remarks. Type specimens depicted in Ahl (1931b: 396, fig. 272). The syntypes were collected during the first "Deutsche Zentral-Afrika-Expedition", 1907-1908; see also remarks on Hyperolius adolphi-friederici.

\section{Hyperolius jackie Dehling, 2012: 54, figs 1, 2.}

Holotype. ZMB 77476, "a natural pond at Karamba (2²8'44.28"S, 2906'44.50"E, 1940 m a.s.1.), Nyungwe National Park, Rwanda", coll. Jonas Maximilian Dehling, 20.III.2011.

Paratypes. ZMB 77477-77480, coll. 19.-20. III.2011; ZMB 77481, coll. 3.IV.2011; ZMB 77782, coll. 18.III.2012; ZMB 77783, coll. 24.III.2012; otherwise same collecting details as holotype.

Present name. Hyperolius jackie Dehling, 2012.
Hyperolius jacobseni Channing in Channing, Hillers, Lötters, Rödel, Schick, Conradie, Rödder, Mercurio, Wagner, Dehling, Du Preez, Kielgast \& Burger, 2013: 327, fig. 6, third row left, fig. 12 B.

Holotype. ZMB 77280, "near Gatiko, Central African Republic, 54'43"N, 2040'2"E”, coll. Niels Jacobsen, 29.VIII.2006.

Paratypes. ZMB 77281-77298 same collecting data as for the holotype.

Present name. Hyperolius jacobseni Channing in Channing, Hillers, Lötters, Rödel, Schick, Conradie, Rödder, Mercurio, Wagner, Dehling, Du Preez, Kielgast \& Burger, 2013.

Hyperolius kandti Ahl, 1931a: 62.

Holotype. ZMB 46526, "Kivu-See” [Lake Kivu, Rwanda and Democratic Republic of the Congo], coll. Richard Kandt.

Present name. Hyperolius viridiflavus (Duméril \& Bibron, 1841).

Remarks. The Prussian medical officer and discoverer of one of the sources of the Nile, Richard Kandt (who used Kantorowicz until 1894) explored the northwestern part of German East Africa from October 1897 to January 1898, and the region around Lake Kivu between 1898 and 1902 (Kandt 1899, 1900, 1921; Bindseil 1988).

\section{Hyperolius karissimbiensis Ahl, 1931a: 74.}

Holotype. ZMB 46525, "Bambusurwald und Waldwiesen ca. $2400 \mathrm{~m}$ hoch, beim Dorf des Mhcabu Gahama am Karissimbi" [Mount Karisimbi, Muzanze District, Northern Province, Rwanda; bamboo jungle and forest meadows at $2400 \mathrm{~m}$ a.s.1.], coll. Johann Gustav Hermann Schubotz.

Present name. Hyperolius viridiflavus (Duméril \& Bibron, 1841).

Remarks. Depicted in Ahl (1931b: 348, fig. 223). The holotype was collected during the first "Deutsche Zentral-Afrika-Expedition”, 1907-1908.

\section{Hyperolius kivuensis Ahl, 1931a: 26.}

Holotype. ZMB 36098, "Kivu-See” [Lake Kivu, Rwanda and Democratic Republic of the Congo], coll. Richard Kandt.

Present name. Hyperolius kivuensis Ahl, 1931a.

Remarks. Depicted in Ahl (1931b: 280, fig. 151); see also remarks under $H$. kandti.

\section{Hyperolius kivuensis}

see Hyperolius bituberculatus (unlocated type specimens), Hyperolius ipianae, Hyperolius multifasciatus, Hyperolius raveni, Hyperolius simus. 


\section{Hyperolius koehli Ahl, 1931a: 121.}

Holotype. ZMB 26089, "Kissenji, Deutsch-Ost-Afrika" [on the northeast shore of Lake Kivu close to the border of Democratic Republic of the Congo, Rwanda], coll. Franz Koehl (Köhl).

Present name. Hyperolius viridiflavus (Duméril \& Bibron, 1841).

Remarks. First Lieutenant, later Captain, Köhl served from 1912 on in the colonial "Schutztruppe" of Deutsch Ostafrika at Kissenji, and from 1916 on in various missions under General Paul Emil von Lettow-Vorbeck, e.g. at Taveta [Kenya], Port Amelia [Pemba, Cabo Delgado Province, Mozambique] and Medo [Metoro, Mozambique] (Haup 1988; Fecitt 2011).

\section{Hyperolius kwidjwiensis Ahl, 1931a: 38.}

Holotype. ZMB 52449. "Insel Kwidjwi im Kivu-See" [Idjwi (Ijwi) Island, Lake Kivu, Democratic Republic of the Congo], coll. Johann Gustav Herrmann Schubotz, VI/1909.

Present name. Hyperolius viridiflavus (Duméril \& Bibron, 1841).

Remarks. Drawing in Ahl (1931b: 296, fig. 172).

\section{Hyperolius laticeps Ahl, 1931a: 69.}

Holotype. ZMB 46529, “Togo”, coll. Leopold Fritz Wilhelm Edmund Conradt, 17.XII.1892.

Present name. Hyperolius laticeps Ahl, 1931a.

Remarks. Depicted in Ahl (1931b: 342, fig. 216). Conradt was a German planter and colonial officer, who was working in "Derema" [Derema, Usambara Mountains, Korogwe District, Tanga Region, Tanzania] at the end of 1891. His collections of vertebrates made during this time were described by Matschie (1892). Later he went to Togo, being stationed in Bismarckburg [Sotouboua Prefecture, Centrale Region, Togo] from VII/1892-XII/1893 (Weidmann 1894; Conradt 1896). See also remarks on Megalixalus laevis concerning his activities in Tanzania and Cameroon.

The specimen is a juvenile Hyperolius and cannot be assigned confidently to a particular West African species.

\section{Hyperolius latifrons Ahl, 1931a: 65.}

Holotype. ZMB 50278, "Bambusurwald und Waldwiesen ca. $2400 \mathrm{~m}$ hoch, beim Dorf des Mhcabu Gahama am Karissimbi" [Mount Karisimbi, Muzanze District, Northern Province, Rwanda; bamboo jungle and forest meadows at 2400 m a.s.1.], coll. Johann Gustav Hermann Schubotz.

Present name. Hyperolius castaneus Ahl, 1931a.

Remarks. Depicted in Ahl (1931b: 335, fig. 208). The holotype was collected during the first "Deutsche Zentral-Afrika-Expedition", 1907-1908.
Hyperolius leptosomus Peters, 1877a: 619, pl., fig. 5.

Holotype. ZMB 9175, "Chinchoxo (Westafrika)" [Cabinda Province, Angola], don. Africanische Gesellschaft.

Present name. Afrixalus "quadrivittatus" Pickersgill, 2007b.

Remarks. See also remarks on Hyperolius adspersus.

Hyperolius lupiroensis Channing in Channing, Hillers, Lötters, Rödel, Schick, Conradie, Rödder, Mercurio, Wagner, Dehling, Du Preez, Kielgast \& Burger, 2013: 330, fig. 6 , third row second right, fig. $12 \mathrm{G}$.

Holotype. ZMB 77299, "near Lupiro, 8²5'29.3"S, $36^{\circ} 41^{\prime} 33.1$ "E, Ifakara district, Tanzania", coll. A. Danby, 9.VII.2007.

Paratype. ZMB 77300, same collecting data as for the holotype.

Present name. Hyperolius lupiroensis Channing in Channing, Hillers, Lötters, Rödel, Schick, Conradie, Rödder, Mercurio, Wagner, Dehling, Du Preez, Kielgast \& Burger, 2013.

\section{Hyperolius macrodactylus Ahl, 1931a: 95.}

Holotype. ZMB 39100, "Kivu-See" [Lake Kivu, Rwanda and Democratic Republic of the Congo], coll. Richard Kandt.

Present name. Hyperolius viridiflavus (Duméril \& Bibron, 1841).

Remarks. Depicted in Ahl (1931b: 369, fig. 244); see further comments under $H$. kandti.

Hyperolius marginatus Peters, 1854: 627.

Holotype. ZMB 4806, "Macanga“" [Makanga Region, Tete Province, Mozambique], coll. Wilhelm Carl Hartwig Peters.

Present name. Hyperolius marginatus Peters, 1854.

Remarks. Depicted in Peters (1882b, pl. 22, fig. 8) and Tornier (1896, pl. 4, fig. 89). Bauer et al. (1995: 44) erroneously listed ZMB 1806 as holotype. Peters visited the Macanga region north and northwest of Tete because of its goldmines. Here he also collected the holotype of H. marginatus on the Pomfe River (one of the northern tributaries of the Zambezi) on 12 June 1845 (Hand 1848; Peters 1882b: 166; map in Futterer 1895).

Hyperolius marginatus

see Hyperolius argentovittis, Hyperolius callichromus, Hyperolius decipiens, Hyperolius graueri.

Hyperolius mariae Barbour \& Loveridge, 1928: 217.

Paratype. ZMB 38029 [ex MCZ, former inventory number unknown], "Derema bei Amani, Usambara Mts., Tan- 
ganyika Territorium" [Derema, Korogwe District, Tanga Region, Tanzania], coll. Mary V. Loveridge, 30.XI.1926.

Present name. Hyperolius mariae Barbour \& Loveridge, 1928.

Remarks. Holotype: MCZ A-13267; Paratypes MCZ A-13262-13266 and MCZ A-13268-13276, all from "Derema nr. Amani, Usambara Mtns., Tanganyika Territory”, coll. Mary V. Loveridge, 30.XI.1926. ZMB 38029 was donated by A. Loveridge (MCZ) in the 1930s and inventoried in 1958.

\section{Hyperolius mariae}

see Hyperolius bitaeniatus, Hyperolius melanophthalmus, Hyperolius noblei, Hyperolius renschi (unlocated type specimens), Hyperolius rubriceps, $\mathrm{Hy}$ perolius udjidjiensis.

\section{Hyperolius marmoratus}

see Hyperolius albifrons, Hyperolius asper, Hyperolius breviceps, Hyperolius dermatus, Hyperolius fuelleborni, Hyperolius granulosus, Hyperolius guttolineatus (unlocated type specimens), Hyperolius marungaensis, Hyperolius microstictus, Hyperolius nyassae, Hyperolius taeniatus, Hyperolius variegatus, Hyperolius vermicularis.

\section{Hyperolius marungaensis Ahl, 1931a: 77.}

Holotype. ZMB 10736, "Marunga, Angola” [in error, see remarks], coll. Richard Böhm.

Present name. Hyperolius marmoratus Rapp, 1842.

Remarks. Depicted in Ahl (19831b: 351, fig. 226). Ahl (1931a, b) placed the locality "Marunga" erroneously within Angola because a village of this name exists in the province of Cuando Cubango (see also Marques et al. 2018: 93).

The zoologist and anatomist Böhm, together with the explorer Paul Reichard, travelled on behalf of the "Africanische Gesellschaft" from Zanzibar via Bagamojo [27 July 1880] to Tabora, which they reached two-and-a half months later. From here they turned to Kakoma [southeast of Tabora, Tabora Division, Tanzania], where they stayed for over a year. Then they continued to Jagonda [just northeast of Kakoma]. From Jagonda, Böhm and the topographer Emil Kaiser went on a journey to Lake Tanganyika, lasting several months. They reached Karema on the western shore of the lake [Mpanda District, Katavi Region, Tanzania] and returned to Jagonda on December 23, 1881. In March 1882 they travelled along the Wala River. Dr. Kaiser died during an expedition to Lake Rukwa near Upia on 27 October 1882. Towards the end of December 1882, Böhm and Reichard left Jadonda for Karema, crossed Lake Tanganyika to Mpala (at the mouth of the Lufuku River, Tanganyika Province, Democratic Republic of the Congo) and reached the "Marunga Land" in July 1883. From here they turned southwest and discovered Lake Upemba in the Urua region [Upemba, Bukama
Region, Haut-Lomami Provinz, Democratic Republic of the Congo]. On 27 March 1884 Böhm died in southern Urua, south of the Lake Upemba (Schalow 1888, Weidmann 1894). Based on Böhm's itinerary, it is clear that he found the holotype of $H$. marungaensis in the Marunga Highlands, where he collected extensively in summer 1883 (Schalow 1886, 1888). Therefore, we correct the type locality to "northern Marunga or Marungu Region southwest of Lake Tanganyika, Kalemie Territory, Tanganyika Province, Democratic Republic of the Congo".

\section{Hyperolius maximus Ahl, 1931a: 91.}

Holotype. ZMB 36113, "Ossidinge” [Ossidinge station (Mamfe), on the left bank of the Cross River, Southwest Region, Cameroon], coll. Alfred Mansfeld.

Paratypes. ZMB 43548-43552, "Busa" [sic], Buea [Fako District, Southwest Region, Cameroon], coll. Paul Preuss (Preuß).

Present name. Hyperolius concolor guttatus Peters, 1875, according to Frétey et al. (2014).

Remarks. Depicted in Ahl (1931b: 366, fig. 241). Ahl (1931a: 92) mentioned eight specimens from "Ossidinge, Busa [sic, Buea], Guinea”. One paratype MCZ A-17639 from "Guinea", coll. Pel, don. Schlegel (Leiden) was sent to MCZ in exchange in 1932 (Barbour and Loveridge 1946: 128); another paratype could not be located. The colonial officer and ethnologist Mansfeld, who collected the holotype, arrived in Ossidinge on 30 August 1904 and was stationed there until 1907 (Mansfeld 1908).

\section{Hyperolius melanophthalmus Ahl, 1931a: 68.}

Syntypes. ZMB 85670-85672, “Zanzibar” [Unguja Island, Tanzania], coll. Moriz Tup.

Present name. Hyperolius mariae Barbour \& Loveridge, 1928.

Remarks. Depicted in Ahl (1931b: 342, fig. 215). Another paratype, MCZ A-17640 from "Zanzibar", coll. Tup, was sent in exchange in 1932 (Barbour and Loveridge 1946: 128).

\section{Hyperolius micops \\ see Hyperolius acuticeps.}

\section{Hyperolius microstictus Ahl, 1931a: 80.}

Syntypes. ZMB 36100 and ZMB 77762 (formerly part of ZMB 36100), "Longa, oberhalb Minnescra [sic]" [above Minnesera, today Cuito Cuanavale, on left bank of Longa River (a right tributary of Cuito river) and confluence with Quiriri (Kuarliri) River, Cuando Cubango Province, Angola, ca. $1250 \mathrm{~m}$ a.s.l.], coll. [Hugo Baum, see below], 14.I.1900. 
Present name. Hyperolius marmoratus Rapp, 1842.

Remarks. Depicted in Ahl (1931b: 353, fig. 228). Ahl (1931a: 81) mentioned no collector or donor for the type specimens. However, the syntypes were mentioned earlier by Sokolowski (1903: 541 f.) who described two Rappia specimens collected by the botanist Baum on 14 January 1900 "am Longa oberhalb Minnesera" during the "Kunene-Sambesi-Expedition 1899-1900" led by Pieter van der Kellen. Based on Baum's notes, Sokolowsy (1. c.) almost literally described the same observations, as was later repeated by Ahl (1931a: 81), i.e. "[...] kleine auf Blättern von Sträuchern nach Art unserer Laubfrösche sitzende Fröschchen [...]" [...small frogs sitting on leaves of bushes like our tree frogs ...]. Baum's expedition route in Angola was illustrated by Heintze (2007, map 2).

\section{Hyperolius mohasicus Ahl, 1931a: 85.}

Holotype. ZMB 36094, "Mohasi-See, Ruanda" [Lake Muhazi, Eastern Province, Rwanda], coll. Johann Gustav Hermann Schubotz, 29.VII.1907.

Present name. Hyperolius viridiflavus (Duméril \& Bibron, 1841).

Remarks. Depicted in Ahl (1931b: 360, fig. 236). The holotype was collected during the first "Deutsche Zentral-Afrika-Expedition", 1907-1908.

\section{Hyperolius monticola Ahl, 1931a: 102.}

Holotype. ZMB 39010, "Niansa, Ruanda, 1500 m hoch" [Nyanza (Nyabisindu), Nyanza District, Southern Province, Rwanda, 1500 m a.s.1.], coll. Johann Gustav Hermann Schubotz, 10.VIII.1907.

Present name. Hyperolius viridiflavus (Duméril \& Bibron, 1841).

Remarks. Depicted in Ahl (1931b: 377, fig. 251). The holotype was collected during the first "Deutsche Zentral-Afrika-Expedition", 1907-1908.

\section{Hyperolius multicolor Ahl, 1931: 94.}

Syntypes. ZMB 39002, 39005, 74953-74956, "Bambusurwald und Waldwiesen ca. $2400 \mathrm{~m}$ hoch, beim Dorf des Mhcabu Gahama am Karissimbi" [Mount Karisimbi, Muzanze District, Northern Province, Rwanda; bamboo jungle and forest meadows at $2400 \mathrm{~m}$ a.s.1.], coll. Johann Gustav Hermann Schubotz.

Present name. Hyperolius viridiflavus (Duméril \& Bibron, 1841).

Remarks. Drawing in Ahl (1931b: 368, fig. 243). The syntypes were collected during the first "Deutsche Zentral-Afrika-Expedition", 1907-1908. Another syntype MCZ A-17641 was sent in exchange to MCZ in 1932 (Barbour and Loveridge 1946: 128).

\section{Hyperolius multifasciatus Ahl, 1931a: 24.}

Holotype. ZMB 36109, "Missionsstation Rungwe" [station of the Moravian Church (Herrnhuter Brüdergemeinde), Rungwe village, Mbeya Region, Tanzania], coll. Friedrich Georg Hans Heinrich Fülleborn.

Present name. Hyperolius kivuensis Ahl, 1931a.

Remarks. Drawing in Ahl (1931b: 278, fig. 149).

\section{Hyperolius narinus Ahl, 1931a: 109.}

Holotype. ZMB 36090, “Togo (Misahöhe)” [Missahomé, Agou Prefecture, Plateau Region, Togo], coll. Julius Smend, 9.II.1903.

Paratypes. ZMB 36121 (two larvae), same collection data as for holotype.

Present name. Hyperolius concolor (Hallowell, 1844).

Remarks. Drawing in Ahl (1931b: 383, fig. 258). First Lieutenant Smend served from 1901 as district manager at the German colonial station Misahöhe.

Hyperolius nasutus see Rappia dombeensis.

Hyperolius ngoriensis Ahl, 1931a: 60.

Syntypes. ZMB 85760-85763, “Krater des Ngori-See's [sic] (Deutsch-Ost-Afrika)" [Ngozi Crater Lake, Poroto Mountains range, Rungwe District, Mbeya Region, Tanzania], coll. Friedrich Georg Hans Heinrich Fülleborn.

Present name. Hyperolius pictus Ahl, 1931a.

Remarks. Depicted in Ahl (1931b: 324, fig. 198).

\section{Hyperolius nigropalmatus Ahl, 1931 a 104.}

Holotype. ZMB 85764, "Lolodorf, Kamerun" [Lolodorf, Océan Division, South Province, Cameroon], coll. Oswald Rudolf Johannes Gerhard Jacob, 1907.

Present name. Hyperolius phantasticus (Boulenger, 1899).

Remarks. Drawing in Ahl (1931b: 378, fig. 253). In 1907 First Lieutenant Jacob (also spelled Jakob) served in the "Schutztruppe für Kamerun" as manager of the German Colonial Station Lolodorf (Hoffmann 2007).

Hyperolius nitidulus Peters, 1875: 209, pl. 3, fig. 4.

Holotype. ZMB 7729, "Yoruba (Lagos)" [Nigeria], don. Christian Ferdinand Friedrich von Krauss.

Present name. Hyperolius nitidulus Peters, 1875.

Remarks. Depicted in Tornier (1896, pl. 4, fig. 118). The traveler, botanist and malacologist Krauss became 
director of the Königliche Naturalienkabinett in Stuttgart in 1890. He studied and collected southern African flora, fauna and geological samples between 1838 and 1840 .

\section{Hyperolius noblei Ahl, 1931a: 118.}

Holotype. ZMB 85765, "Kilwa (Deutsch-Ost-Afrika)" [Kilwa (Kivinje), Kilwa District, Lindi Region, Tanzania], coll. Julius Vosseler, VI/1907.

Present name. Hyperolius mariae Barbour \& Loveridge, 1928.

Remarks. Drawing in Ahl (1931b: 400, fig. 275). On behalf of the Prussian government, the German zoologist and later director of the Hamburg Zoological Garden, Vosseler went to Deutsch-Ostafrika where he worked at the "Biologisch-Landwirtschaftliche Institut Amani" from 1903 to 1908, together with Stuhlmann (see above) (Schnee 1920b; Grimpe 1931; Wenzel Geißler et al. 2020).

\section{Hyperolius nossibeensis Ahl, 1930d: 66.}

Syntypes. ZMB 50098-50100, "Nossi-Bé” [Nosy Be (island), Diana Region, Madagascar], don. Senckenberg Museum [in error]; corrected here to "Lunda" [Lunda Sul Province, Angola], coll. Max Buchner, XII/1979VI/1880 (see below).

Present name. Hyperolius angolensis Steindachner, 1867 (fide Marques et al. 2018).

Remarks. Depicted in Ahl (1931b: 421, fig. 294, probably ZMB 50089). The three type specimens of $H$. nossibeensis were originally inventoried in 1882 as "3 [specimen] Hyperolius vermiculatus Pts." under inventory number ZMB 10100. According to the ZMB inventory catalogue the specimens were collected by "Dr. M. Buchner" at "Lunda".

Because of a reading error, assuming ZMB 10100 instead of ZMB 10101, a new label was written for this collection jar in the 1920 s, for which erroneously the information of ZMB 10100 was adopted, viz. "Nossi-Bé" and "Museum Senckenberg". This transmission error and the specimens became the basis for Ahl's (1930) new description of $H$. nossibeensis. In 1992, Frank Glaw (ZSM) located the syntypes of $H$. nossibeensis in the ZMB collection. The jar with the label from the 1920 s mentioned Mantidactylus granulatus from Nosy Be, ZMB 10100. Glaw and Vences (1993: 216) discussed the status and identity of $H$. nossibeensis, synonymized it with Hyperolius marmoratus and corrected the terra typica to "das Äthiopische Afrika" [Ethiopian Africa]. Subsequently the three syntypes were re-inventoried as ZMB 5009850100. This was necessary as the inventory number ZMB 10100 had already been assigned to a specimen of "Mantidactylus granulatus" (= paralectotype of Limnodytes granulatus Boettger, 1881) from "Nosy Bé, don. Museum Senckenberg" (see Glaw and Vences 1993).

The physician Dr. Buchner arrived in Luanda on 5 December 1878 and travelled via Dondo (20 Decem- ber 1878 ) and Malanje (30 January to 22 July 1879 ) to Mussumba in the Lunda Empire (11 December 1879 to June 1880). He returned to Malanje (28 February 1881) and via Golungo and Cazengo travelled back to Luanda, where he arrived at the end of August 1881. He finally returned to Berlin in January 1882 (Heintze 2007).

\section{Hyperolius nyassae Ahl, 1931a: 66.}

Holotype. ZMB 39006, "Langenburg” [Lumbira, Mbeya Region, Tanzania], coll. Friedrich Georg Hans Heinrich Fülleborn.

Paratypes. ZMB 77766-77767 (formerly part of ZMB 39006), "Langenburg"; ZMB 85885-85889, "Rugwe"; ZMB 90953-90989, "Rugwe am Nyassa (D.O.A.)"; ZMB 90980-90992, "Rugwe, D.O.A.”; ZMB 9099390995, "Konde-Nika (D.O.A.)"; ZMB 90996-90999, "Neu-Helgoland", all coll. Fülleborn.

Present name. Hyperolius marmoratus Rapp, 1842.

Remarks. Drawing in Ahl (1931b: 340, fig. 213). Ahl (1931a: 67) mentioned 133 specimens from Langenburg (including the type), Rugwe, Mirambo [sic; Miramba], Konde-Nika, Ipiana, Transvaal, Neu Helgoland and Lindi, collected by Fülleborn and Wilms. A paratype (MCZ A-17642) from "Rugwe" coll. Fülleborn, was sent to MCZ in 1932 (Barbour and Loveridge 1946: 128). Seventy-seven other paratypes, including specimens from Miramba, Ipiana, Transvaal and Lindi, as well as material collected by Wilms could not be located.

\section{Hyperolius obstetricans Ahl, 1931a: 90.}

Holotype. ZMB 77755, "Bipindihof” [Bipindi village, Océan Department, South Province, Cameroon], coll. Georg August Zenker.

Present name. Hyperolius obstetricans (Ahl, 1931a).

Remarks. Photo in Ahl (1931b: 365, fig. 240, horizontally mirrored) showing the specimen on a leaf with 39 eggs. The type previously was regarded as lost, however, we rediscovered the specimen, still sitting on the leaf with the eggs (see Fig. 8). In accordance with Article 75.8 of the International Code of Zoological Nomenclature (ICZN 1999), the rediscovery of the holotype in the ZMB collection in 2012 renders the neotype designation by Perret invalid (1966: 410; MHNG 995.48 from "Foulassi, rivière Lobô"). Since 1988 the species was a member of the genus Alexteroon Perret, 1988. However, recently Ernst et al. (2021) revised the systematic position of Alexteroon and assigned the three species to the genus Hyperolius.

The German naturalist, botanist and gardener Zenker joined the German colonial service as taxidermist in 1889. He was manager of the colonial station Jaunde (Yaoundé, Mfoundi Department, Centre Region, Cameroon) from 1890-1895 (Zenker 1890). In 1896 he settled in Bipindi on the Lokundje River where he collected natural history and ethnological objects extensively and managed different plantations until his death on 6 Febru- 


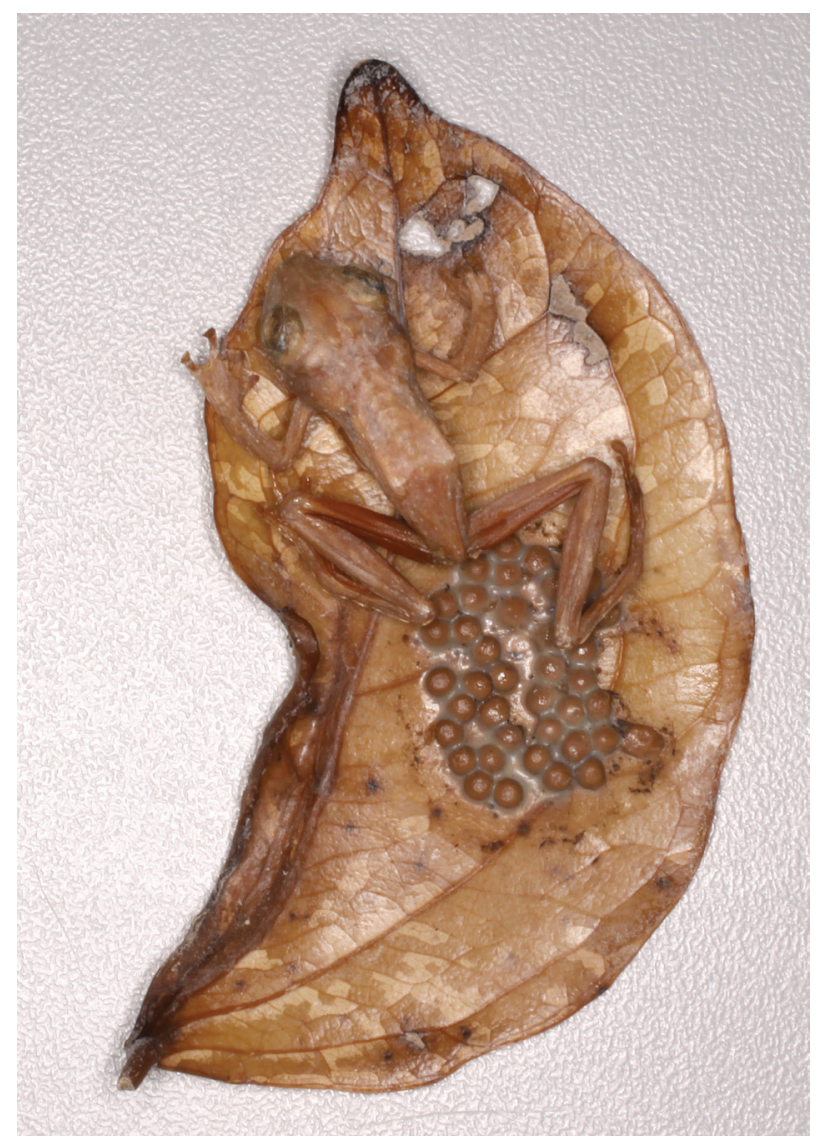

Figure 8. Holotype of Hyperolius obstetricans, ZMB 77755 from "Bipindihof", coll. Zenker.

ary 1922. The main part of his zoological collection is at ZMB (Mildbraed 1923; Frahm and Eggers 2001).

\section{Hyperolius oculatus Ahl, 1931a: 103.}

Holotype. ZMB 58570, "Balaibo am Duki-Ufer" [Balaibo on Duki River, southwest of Lake Albert, Ituri Province, northeastern Democratic Republic of the Congo], coll. Franz Ludwig Stuhlmann, 9.XI.1891.

Paratype. ZMB 85766, "Golei-See [sic]" [Lake Solei or Solai, Nakuru county, Rift Valley Province, Kenya], coll. Arthur Berger, 2.II.1908.

Present name. Hyperolius viridiflavus (Duméril \& Bibron, 1841).

Remarks. Depicted in Tornier (1896, pl. 4, fig. 20), reproduced in Ahl (1931b: 377, fig. 252). From April 1890 to July 1892, Stuhlmann accompanied Mehmed Emin Pasha's [actually Eduard Karl Oskar Theodor Schnitzer] expedition to the East African lake region as a zoologist. This took him as far as the northeastern part of today's Democratic Republic of the Congo (Stuhlmann 1894). Today, his extensive zoological collections are mainly housed at ZMB and in the Zoologisches Museum der Universität Hamburg. The German physician, explorer and hunter Dr. Berger travelled to areas of British East Africa, Uganda, from July 1908 to 1909 . He visited the border area with Democratic Republic of the Congo and Sudan, and returned to Germany via Egypt (Berger 1924,
1942). A large part of the zoological objects he collected is at $\mathrm{ZMB}$.

\section{Hyperolius oeseri Ahl, 1931a: 51.}

Holotype. ZMB 31867, "Grand Bassa, Liberia” [Grand Bass County, Liberia], coll. Richard Oeser.

Present name. Hyperolius fusciventris Peters, 1876.

Remarks. The German physician Dr. Oeser undertook various journeys, e.g. to East Asia and Indonesia (1923 as a ship's doctor), to the USA (1925), to Central America and northern South America (1931-32) as well as to Cameroon (1936). In spring 1928 he undertook a journey along the West African coast, collecting in Benin, Nigeria, Fernando Pó, Sao Tomé and Principe, Angola, Namibia and Liberia. He collected the type material of $H$. oeseri and Hyperolius trifasciatus Ahl (see below). A large part of his collection was sold through the zoological wholesaler "Scholze \& Peotzschke" in Berlin (Mertens 1975).

\section{Hyperolius olivaceus Buchholz \& Peters in Peters, 1876: 120.}

Syntypes. ZMB 8829 and ZMB 53264-53265 (formerly part of ZMB 8829), "Limbareni am Ogowe" [Lambaréné on the river Ogooué (or Ogowe), Moyen-Ogooué Province, Gabon], coll. Reinhold Wilhelm Buchholz.

Present name. Hyperolius olivaceus Buchholz \& Peters in Peters, 1876.

\section{Hyperolius olivaceus}

see Hyperolius fimbriolatus.

\section{Hyperolius petersi Ahl, 1931: 23.}

Holotype. ZMB 5573, "Mombas" [Mombasa, Kenya], coll. Carl Claus von der Decken.

Present name. Hyperolius concolor (Hallowell, 1844).

Remarks. Depicted in Ahl (1931b: 274, fig. 144). The German explorer, geographer, zoologist and botanist von der Decken arrived in East Africa (Zanzibar) in September 1860 . Until 1865 he undertook several expeditions to Kilwa, the Malawi Lake region, the Usambara Mountains and Mount Kilimanjaro in Tanzania and to Bardera [Baardhere, southwestern Somalia] (Decken 1869; Verdcourd 2002).

Hyperolius phantasticus see Hyperolius chabanaudi, Hyperolius nigropalmatus.

\section{Hyperolius phrynoderma Ahl, 1931a: 71.}

Syntypes. ZMB 39000 and ZMB 77734-77736 (formerly part of ZMB 39000), "Zentrales Deutsch-Ost-Afrika" 
[Central German East Africa, Central Tanzania, see comment below] collected during the first "Deutsche ZentralAfrika-Expedition", 1907-1908.

Present name. Hyperolius cf. viridiflavus (Duméril \& Bibron, 1841).

Remarks. Depicted in Ahl (1931b: 344, fig. 218). Another syntype, MCZ A-17643 with identical collecting data was sent in exchange to MCZ in 1932 (Barbour and Loveridge 1946: 130). Laurent (1961: 83) erroneously presumed that the five subadult specimens inventoried under ZMB 13701 could be the types of Hyperolius phrynoderma, but these specimens were collected at "Bukoba" by Stuhlmann and do not correspond with the locality given by Ahl for the types. Ahl's (1931a: 72) vague locality information for the $H$. phrynoderma types is probably wrong and mainly based on the transfer of the expedition name to a region, i.e. "Central German East Africa" which would be geographically equivalent to today's central Tanzania. However, the zoological collections of this expedition mainly originate from northeast Tanzania, Rwanda and the adjacent Democratic Republic of the Congo, more precisely from the region between Bukoba on the western shore of Lake Victoria, Ischangi in the south of Lake Kiwu and Irumu in the Ituru Province of northeastern Democratic Republic of the Congo (see comments in Barbour and Loveridge 1946: 130; map in Schubotz 1909).

Currently, the status of this taxon is uncertain. In comparison to species in the H. marmoratus / viridiflavus group, the body is comparatively slender and the snout more pointed. Dorsal warts are distinct, and arranged very regularly, even in the single adult frog (ZMB 39000). Juveniles of the $H$. marmoratus / viridiflavus group have warty skin, adults usually have smooth skin). Drewes (1997) described a superficially similar-looking frog from the Serengeti, Hyperolius orkarkarri, which is currently regarded as a synonym of $H$. glandicolor (see Channing and Howell 2006).

Under the leadership of Adolf Friedrich, Duke of Mecklenburg, the first "Deutsche Zentral-Afrika-Expedition" was carried out from 1907 to 1908 , to scientifically investigate the area of the African Rift Valley (see also remarks on Hyperolius adolphi-friederici).

\section{Hyperolius picturatus Peters, 1875: 206, pl. 2, fig. 2.}

Syntypes. ZMB 3063 and ZMB 76991-76994 (formerly part of ZMB 3063), "Boutry" [Butre (Bootry), Ahanta West District, Western Region, Ghana], coll. Hendrik Severinus Pel, don. Hermann Schlegel (Museum Leyden).

Present name. Hyperolius picturatus Peters, 1875.

Remarks. Depicted in Ahl (1931b: 333, fig. 206) copied from Peters (1875, pl.2, fig. 2).

\section{Hyperolius pictus Ahl, 1931a: 44.}

Holotype. ZMB 86001, "Krater des Ngori-See's [sic]" [Ngozi Crater Lake, Poroto Mountains range, Rungwe
District, Mbeya Region, Tanzania], coll. Friedrich Georg Hans Heinrich Fülleborn.

Paratypes. ZMB 85767-85781, ZMB 86002-86005, „Krater des Ngori-See's”, coll. Fülleborn; ZMB 46533, ZMB 85782-85818, ZMB 85876-85878, "Nairobi”, coll. F. Thomas; ZMB 85819-85823, "Uhehe", coll. Goetze; ZMB 85824, "Rungwe", coll. Goetze; ZMB 85825, "Rugwe" and ZMB 77720, "Nyassa See", coll. Fülleborn; ZMB 85826-85827, "Rugegewald", coll. Grauer; ZMB 90454-90456, "Bukoba", coll. Schubotz; ZMB 90457-90479, "Bukoba", coll. Deutsche Zentralafrica Expedition, Schubotz, 15.VI.1907; ZMB 90480-90483, "Bukoba", coll. ? Stuhlmann, III/1892.

Present name. Hyperolius pictus Ahl, 1931a.

Remarks. Five drawings showing the variation of this taxon are provided by Ahl (1931b: 302, fig. 176). Two paratypes, MCZ A-17644-17645 from "Uhehe", coll. Goetze were sent in exchange to MCZ in 1932 (Barbour and Loveridge 1946: 128). Ahl (1931a: 45) mentioned 114 specimens of which we could not locate the material collected at "Iringa", "Kivu-See", "Kissenji" and "Kinga-Gebirge".

\section{Hyperolius pictus \\ see Hyperolius ngoriensis.}

\section{Hyperolius pulcher Ahl, 1931a: 48.}

Holotype. ZMB 36088, “Japoma, Kamerun" [suburb east of Douala, Region Littoral, Cameroon], coll. Hans Schäfer, 1.X.1910.

Present name. Hyperolius concolor guttatus Peters, 1875, according to Frétey et al. (2014).

Remarks. Drawing in Ahl (1931b: 308, fig. 183), reproduced by Frétey et al. (2014, fig. 6), who also provided a photograph and redescribed the holotype. In 1910 the naval physician Schäfer collected various botanical and zoological objects in Cameroon, e.g. at Mount Manengouba, Mount Cameroon (Fako) and Japoma, that are accessioned at ZMB and the Botanische Museum Berlin-Dahlem [Botanical Museum and Garden Berlin-Dahlem] (Urban 1917).

\section{Hyperolius pulchromarmoratus Ahl, 1931a: 92.}

Holotype. ZMB 77751, "Britisch Ostafrika" [Kenya], coll. Richard Fritz Paul Hübner [later Huebner].

Present name. Hyperolius glandicolor Peters, 1878.

Remarks. Drawing in Ahl (1931b: 367, fig. 242). Huebner worked from 1894 to 1913 as a merchant, banker, farmer and administrator and from 1901 to 1903 as Municipal Commissioner of Nairobi in (British) East Africa. He was active in Zanzibar (1894-1896), Mombasa (1896-1899), Nairobi (1899-1905), Kibwezi (1905-1908, together with G. R. O. Scheffler), and Voi (1908-1913), and undertook a journey from Mombasa to Kampala from June to November 1899. In 1913 he 
travelled to Germany for a convalescent stay because of health problems. However, his already planned return to Kenya was thwarted by the beginning of the First World War. In his spare time he was engaged in nature observations and collected interesting zoological objects, which he sent to ZMB (Sieberg 1998).

\section{Hyperolius punctatissimus Ahl, 1931a: 41.}

Syntypes. ZMB 39013, 79403-79439 and 80407 (formerly part of ZMB 39013), coll. Johann Gustav Hermann Schubotz; ZMB 43553, 43584-43590 and 79402, coll. Franz Ludwig Stuhlmann; all from "Bukoba" [Bukoba Urban District, Kagera Region, Tanzania],

Present name. Hyperolius viridiflavus (Duméril \& Bibron, 1841).

Remarks. Two drawings showing the variation of this taxon are illustrated by Ahl (1931b: 299, fig. 174). Ahl (1931a: 42) mentioned 89 specimens and explicitly states that the types ["die Typen"] are among the material from "Bukoba" without specifying a number or the collector. Therefore we do not regard specimens listed by Ahl (18931a: 42) from "Rugege-Wald", "Vulkangebiet nord-östlich des Kivu-See's", "Sisse" [sic], "W-Niansa" [Sesse or Ssese Archipelago, Lake Victoria, Uganda], and "Njamagelo" as part of the type series, and restrict the type series to those frogs from Bukoba.

\section{Hyperolius pygmaeus Ahl, 1931a: 22.}

Holotype. ZMB 36102, “Tanga” [Tanga Region, Tanzania], coll. Georg Martienssen.

Present name. Afrixalus stuhlmanni (Pfeffer, 1893).

Remarks. Drawing in Ahl (1931b: 273, fig. 143). Hyperolius pygmaeus Ahl, 1931a, is a junior homonym of Hyperolius pygmaeus Meyer, 1875 (=Litoria pygmaea).

Between December 1896 and June 1899, the German planter Martienssen sent amphibians and reptiles from the German colony in East Africa to ZMB. The locality "Tanga" as given by Ahl (1931a) most likely refers to today's Tanga region. It is clear from Martienssen's correspondence with $\mathrm{ZMB}$ that the amphibians he sent to Berlin were collected, with few exceptions (e.g. Ukami), exclusively in "Magrotto" [plantation in southern part of Mlinga Mountains, East Usambara, Tanga Region] and "Plantation Schöller" [Bondei County near Ngomeni, east of the Mlinga Mountains, ca. $25 \mathrm{~km} \mathrm{SW}$ of Tanga town] (see Gvoždík et al. 2014). Martienssen also supported the African expedition to Kilimanjaro undertaken by Yngve Sjöstedt from 1905-1906 by providing porters (Sjöstedt 1910: 3). The correspondence between Martienssen and the ZMB curators (especially Gustav Tornier), kept in the archives of the Historical Department at ZMB, reveals that "Laubfrösche" [Tree frogs, Hyperolius spp. (s. 1.)] sent by Martienssen to ZMB were all collected on the "Magrotto" plantation between 17 April and 18 May 1897.
Hyperolius quadratomaculatus Ahl, 1931a: 127.

Holotype. 36108, "Mohorro, Deutsch-Ost-Afrika" [Mohoro (Muhoro), Pwanai Region, Tanzania], coll. Karl Grass, 22.II.1901.

Present name. Hyperolius quadratomaculatus Ahl, 1931.

Remarks. Depicted in Ahl (1931b: 413, fig. 285). The Imperial District Administrator Graß (sometimes Grass) served his colonial service as forestry assessor: in 1899 at the forest bureau "Usimbe" [Rufiji District, Pwani Region, Tanzania], and from 1900 onwards at the joint forest and district administrative office "Mohorro" (Graß 1904; Schabel 1990). Until 1901, he sent zoological specimens to $\mathrm{ZMB}$ (he was stationed in Africa longer).

\section{Hyperolius raveni Ahl, 1931a: 36.}

Holotype. ZMB 77750, "Vulkangebiet nord-östlich des Kivu-See's" [volcano region northeast of Lake Kivu, Virunga Mountains, along the border between Rwanda and the Democratic Republic of the Congo], coll. Werner Alborus von Raven, X/1907.

Present name. Hyperolius kivuensis Ahl, 1931a.

Remarks. Drawing in Ahl (1931b: 292, fig. 168). The holotype was collected during the first "Deutsche Zentral-Afrika-Expedition", 1907-1908.

\section{Hyperolius riggenbachi} see Hyperolius hieroglyphicus, Rappia riggenbachi.

\section{Hyperolius rosaceus Ahl, 1931a: 105.}

Holotype. 36104, "Klein-Popo, Togo" [Anhéo (Anecho or Popovi), Lacs Prefecture, Maritime Region, Togo], coll. Julius Graf von Zech auf Neuhofen.

Present name. Hyperolius fusciventris Peters, 1876.

Remarks. Depicted in Ahl (1931b: 379, fig. 254). In 1895 , the German colonial officer Count von Zech went to Togo. Here he was assigned the management of the administrative station in Kete Krachi, a position which he held until 1900. He undertook several expeditions into the Togo Hinterland. In 1900 he was appointed District Administrator of the district Anecho in Klein Popo on the Togo coast. From 1905 to 1910 he was the governor of the German colony of Togo (Schnee 1920b).

\section{Hyperolius rubripes Ahl, 1931a: 88.}

Lectotype. ZMB 36110, "Kililana" [opposite Manda Island, Lamu District, Coast Province, Kenya], coll. Clemens Andreas Denhard, 1896.

Paralectotype. ZMB 57530 (formerly part of ZMB 36110), same collecting data as for the lectotype.

Present name. Hyperolius mariae Barbour \& Loveridge, 1928. 
Remarks. Lectotype designation by implication by Laurent (1961: 87) who considered ZMB 36110 (adult male) as "Holotype". In 1878, together with his brother Gustav and Dr. med. Gustav Adolf Fischer, the German engineer and colonial economist C. A. Denhard undertook a research expedition to explore the Tana River (Kenya). One year later he explored the coastal area from Mombasa (Kenya) to Pangani (Tanzania). In 1885 an expedition led him to Lamu Island (Kenya). In 1885 he acquired land from the Sultan of Witu on the mainland coast southwest of Lamu, on which he established plantations and later (1886) ceded parts of it to the German Witu Society. In accordance with the Helgoland-Zanzibar Treaty, the "Wituland", which was under German protectorate from 1885 onwards, was declared a British protectorate on 18 June 1890 (Schnee 1920a).

\section{Hyperolius rugegensis Ahl, 1931a: 82.}

Syntypes. ZMB 77721-77722, "Rugege-Wald, 2000 m hoch" [Nyungwe Forest, Cyangugu Prefecture, West Province, Rwanda], collected during the first "Deutsche Zentral-Afrika-Expedition", VIII/1907.

Present name. Hyperolius castaneus Ahl, 1931a.

Remarks. Depicted in Ahl (1931b: 355, fig. 231).

\section{Hyperolius rwandae Dehling, Sinsch, Rödel and Channing in Channing, Hillers, Lötters, Rödel, Schick, Conradie, Rödder, Mercurio, Wagner, Dehling, Du Preez, Kielgast \& Burger, 2013: 337, fig. 6, lower row, second right, fig. 9 E.}

Holotype. ZMB 77221 (field no: JMD 562, now missing), "from a pond in farmland on the eastern outskirts of Butare, Huye District, South Province, Rwanda (2³7'10.79"S, 2945'08.45"E)”, coll. Jonas Maximilian Dehling, 13. IX. 2010.

Paratypes. ZMB 77222, same collecting data as for the holotype; ZMB 77223, "from the Mugesera wetland south of Lac Mugesera, Bugesera Province, southeastern Rwanda (2¹2'18.92"S, 30¹6'18.18"E)", coll. J. M. Dehling, 27.III.2011; ZMB 77224, "from the Mugesera wetland, Bugesera Province, southeastern Rwanda ( $\left.2^{\circ} 12^{\prime} 15.95^{\prime \prime S}, 30^{\circ} 15^{\prime} 49.25^{\prime \prime E}\right)$ ", coll. Bonny Dumbo and J. M. Dehling, 27.III.2011; ZMB 77225, "from a wetland of the Akagera River, Kihere Province, southeastern Rwanda (2॰13'27.63"S, 3049'39.06"E)”, coll. J. M. Dehling, 31.III.2011; ZMB 77423-77429, "from farmland on the eastern outskirts of Butare, Huye Province, southern Rwanda", coll. Katrin Lümkemann, Katharina Rosar and Christiane Schwarz, X/2009; ZMB 77686-77689, "from farmland on the eastern outskirt of Butare $/ 2^{\circ} 35^{\prime} 44.1^{\prime \prime S}$, 2945'25.6"E)", coll. J.M. Dehling, 27.II.2012; ZMB 77683-77685, "from the Mugesera wetland, Bugesera Province, southeastern Rwanda", coll. J. M. Dehling, 26.II.2012; ZMB 77746-77748, “from a swamp in farmland on the eastern outskirt of Ruhengeri, $\mathrm{Mu}$ sanze District, North Province, Rwanda (1³0'25.73"S, 29³9'12.11"E)", coll. J. M. Dehling, 30.II.2012.

Present name. Hyperolius rwandae Dehling, Sinsch, Rödel and Channing in Channing, Hillers, Lötters, Rödel, Schick, Conradie, Rödder, Mercurio, Wagner, Dehling, Du Preez, Kielgast \& Burger, 2013.

Remarks. The type material of $H$. rwandae, inventoried prior to the publication of the paper, was sent to ZMB in August 2017, however, without containing the holotype (ZMB 77221). On written request, we were informed that the holotype could not be found (J. M. Dehling in litt. 28 August 2017) and must therefore be regarded as lost.

\section{Hyperolius scheffleri Ahl, 1931a: 111.}

Holotype. ZMB 85759, "Kibwezi, Britisch-Ost-Afrika" [Kibwezi Division, Makueni County, Kenya], coll. Georg Richard Otto Scheffler, 28.-29.XII.1905.

Present name. Hyperolius glandicolor Peters, 1878.

Remarks. Scheffler worked from 1899 to 1900 as a horticulturist on plantations of the German East African Society in Usambara (Nguelo and Derema), in the Useguha region [Tanzania] and from 1905 until his death on 10.VI.1911 as a farm manager under managing director Paul Huebner in Kibwezi, British East Africa (Urban 1917; Sieberg 1998).

\section{Hyperolius scriptus Ahl, 1931a: 32.}

Holotype. ZMB 36087, “Tanga” [Tanga Region, Tanzania], coll. Georg Martienssen.

Present name. Hyperolius substriatus Ahl, 1931a.

Remarks. Drawing in Ahl (1931b: 287, fig. 160). For Martienssen's activities in East Africa and locality information and collecting dates see remarks on $H$. pygmaeus (above) and Gvoždík et al. (2014).

\section{Hyperolius simus Ahl, 1931a: 46.}

Lectotype. ZMB 36111, "Usumbura, Tanganyika-See" [Bujumbura, Bujumbura Mairie Province, Burundi], coll. Rudolf Grauer.

Paralectotypes. ZMB 65179-65180 (formerly part of ZMB 36111), same collection data as for the holotype.

Present name. Hyperolius kivuensis Ahl, 1931a.

Remarks. Drawing in Ahl (1931b: 306, fig. 181). Lectotype designation by Laurent (1961: 82, ZMB 36111a= ZMB 36111).

\section{Hyperolius spatzi Ahl, 1931a: 123.}

Lectotype. ZMB 32602, "Bakel-Kidira (Oberes Senegalgebiet)" [Kidira town near Malian border, Bakel Depart- 
ment, Tambacounda Region, East Senegal], coll. Paul Wilhelm Heinrich Spatz.

Paralectotypes. ZMB 74853-74876 (formerly part of ZMB 32602), same locality data as for the lectotype.

Present name. Hyperolius spatzi Ahl, 1931.

Remarks. Lectotype designation by Rödel et al. (2010: 185). Another paratype (MCZ A-17646) from "Bakel-Kidira", coll. Spatz, was sent in exchange to MCZ in 1932 (Barbour and Loveridge 1946: 131).

The German trader and zoologist Spatz carried out various hunting and collecting expeditions in the northern Sahara during which he also collected ethnological and prehistoric objects. In 1884 he travelled to Tunisia and Algeria for the first time. Further journeys to Tunisia were as follows: in spring 1891, together with Alexander Koenig and Koenig's wife; in 1893 and from November 1896 to July 1898 together with Carlo von Erlanger; and from 1904 to 1906 together with Otto Eduard Graf von Zedlitz und Trützschler and Alfred Blanchet. In the early 1920s he travelled to Mauritania, to the lower Senegal River and the Spanish colony of Rio de Oro. The latter he visited again with the Berlin taxidermist Fritz Bock in spring 1926. On behalf of ZMB he made a collecting trip from Dakar to the lower Senegal River from February to July 1928, then accompanied by his son Richard (Spatz 1926 1930; Schulz-Parthu 1997). It was probably on this journey that the holotype of Hyperolius spatzi was collected.

\section{Hyperolius spinosus Buchholz \& Peters in Peters,} 1875: 208, pl. 1, fig. 3.

Syntypes. ZMB 8359 and ZMB 59353-59355 (formerly part of ZMB 8359), "Cameruns" [Douala, Region Littoral, Cameroon], coll. Georg Anton Eugen Reichenow, don. Reinhold Wilhelm Buchholz (Fig. 9).

Present name. Acanthixalus spinosus (Buchholz \& Peters, 1875).

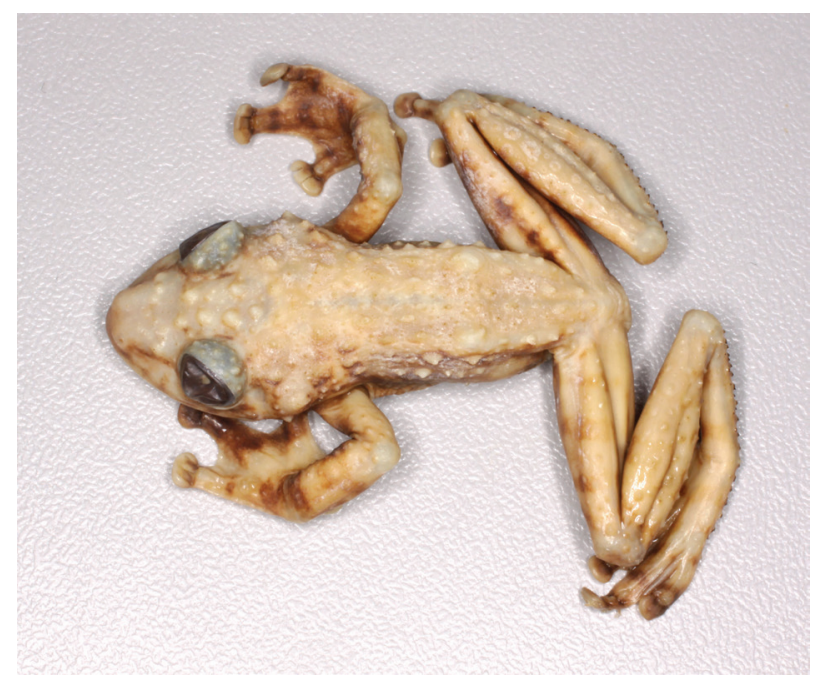

Figure 9. Syntype of Hyperolius spinosus Buchholz \& Peters in Peters, 1875, ZMB 59354 from "Cameruns", coll. Buchholz.
Remarks. Depicted in in Nieden (1910b: 58, fig. 124), copied by Ahl (1931b: 446, fig. 310).

Type locality corrected to "Douala" by Frétey et al. (2014); for further information see also remarks on Hyperolis guttatus. Herrmann (1989: 13) reported two additional syntypes without inventory numbers in the collection of the Zoologisches Museum Greifswald (ZMG) from "Bonjongo" [Southwest Region, Cameroon], coll. Buchholz. However, although the collector is identical, the locality of the two ZMG specimens does not correspond to the type locality "Cameruns" [= part of the present Douala, see above] given by Peters (1875: 209), and thus the ZMG specimens should not be regarded as syntypes.

\section{Hyperolius stenodactylus Ahl, 1931a: 21.}

Holotype. ZMB 85834, "Bipindi, Kamerun" [Bipindi village, Océan Department, South Province, Cameroon], coll. Georg August Zenker.

Present name. Hyperolius stenodactylus Ahl, 1931.

Remarks. Drawing in Ahl (1931b: 271, fig. 140). For Zenker's activities in Cameroon, see the remarks on $\mathrm{Hy}$ perolius obstetricans.

\section{Hyperolius striolatus Peters, 1882a: 9.}

Holotype. ZMB 9300, "Taita" [Taita Hills, Taita-Taveta County, Kenya], coll. Johann Maria Hildebrandt.

Present name. Hyperolius glandicolor Peters, 1878.

Remarks. Depicted in Tornier (1896: pl. 4, fig. 21) and redrawn in Ahl (1931b: 313, fig. 187, right specimen).

\section{Hyperolius stuhlmanni Ahl, 1931a: 113.}

Holotype. ZMB 13008, "Vitschumbi, Südende des A1bert-Eduard-See's" [Witschumbi on the southern tip of Lake Edward, North Kivu Province, Democratic Republic of the Congo], coll. Franz Ludwig Stuhlmann.

Present name. Hyperolius viridiflavus (Duméril \& Bibron, 1841).

Remarks. Drawing in Tornier (1896, pl. 4, fig. 24) reprinted by Ahl (1931b: 396, fig. 271).

\section{Hyperolius substriatus Ahl, 1931a: 84.}

Holotype. ZMB 36099, "Magrotto bei Tanga" [plantation in southern part of Mlinga Mountains, East Usambara, Tanga Region, Tanzania], coll. Georg Martienssen (Fig. 10).

Paratypes. ZMB 23087, "Songea" [Songea district, Ruvuma Region, Tanzania], coll. P. Preuss; ZMB 85719, "Udjidji” [Ujiji, Kigoma Province, Tanzania], coll. Stabsarzt Hösemann; ZMB 85859, "Magrotto bei Tanga", ZMB 85996-85998, "Tanga" [Region], coll. G. Martienssen; ZMB 85858 and ZMB 85863-85865, "Usam- 
bara" [Usambara Mountains], coll. Otto Küttner; ZMB 85860, "Marakiras (1500 m)" and ZMB 85861-85862, "Uhehe", coll. W. Goetze; ZMB 85866 and ZMB 85875, "Amani” [East Usambara Mountains], coll. J. Vosseler; ZMB 85867-85868, "Mwa Mkoro [sic]" [Kwa Mkoro (Kwamkoro, Prinz Albrecht Plantations), Tanga Region], coll. H. Glauning; ZMB 85873, "Dar-es Salaam", coll. F. L. Stuhlmann; ZMB 86018, "Nguelo" [Ngwelo, East Usambara Mountains, Lushoto District, Tanga Region], coll. Auguste Kummer, 1898-99; ZMB 86006-86011 and ZMB 86019-86025, no collecting data.

Present name. Hyperolius substriatus Ahl, 1931.

Remarks. Drawings illustrating the variation of this taxon were published by Ahl (1931b: 358, fig. 234), reprinted from Tornier (1896, pl. 4, figs 65, 67, 69, 71). Ahl (1931a: 85) mentions all together 65 specimens of which we could not locate the material collected from "Konde Nika" and "Derema". For Martienssen's activities in East Africa and locality information and collecting dates, see remarks on H. pygmaeus, as well as Gvoždík et al. (2014).

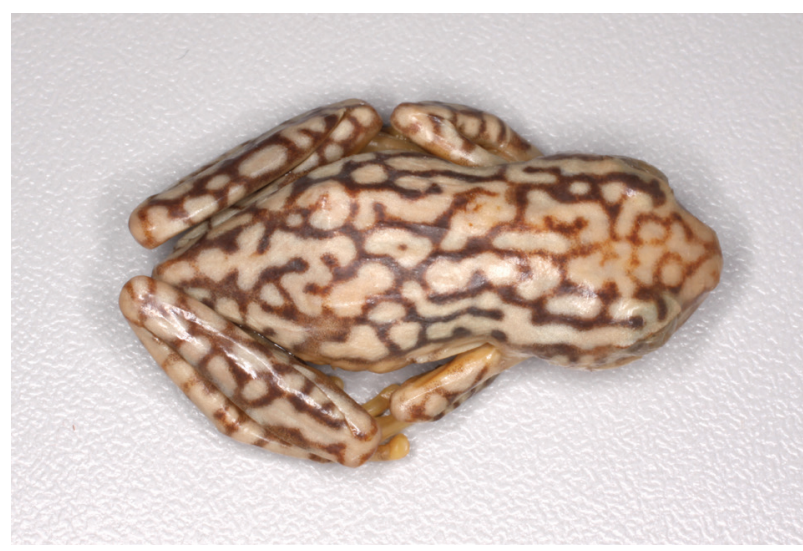

Figure 10. Holotype of Hyperolius substriatus Ahl, 1931a, ZMB 36099 from "Magrotto bei Tanga", coll. Martienssen.

Hyperolius substriatus
see Hyperolius scriptus.

Hyperolius taeniatus Peters, 1854: 627.

Holotype. ZMB 4531, "Boror" [Companhia do Boror, Zambezia Province, Mozambique], coll. Wilhelm Carl Hartwig Peters.

Present name. Hyperolius marmoratus Rapp, 1842.

Remarks. Peters (1882b: 167) mentions that he received only a single specimen from "Boror" in March 1846 and depicted it in plate 22, fig. 7. An additional drawing of the holotype is shown by Tornier (1896, pl. 4, fig. 56).

\section{Hyperolius tettensis Peters, 1854: 628.}

Holotype. ZMB 4812, "Tette" [Tete Province, Mozambique], coll. Wilhelm Carl Hartwig Peters.
Present name. Hyperolius argus Peters, 1854.

Remarks. Peters (1882b: 164) mentioned the sole female type specimen collected by him at "Tette" and synonymized it with a species he described, H. flavoviridis. The latter was later considered by Laurent (1961: 74) as a synonym of another of Peters' species, namely Hyperolius argus. The type is depicted by Peters (1882b, pl. 22, fig. 5). See also remarks on Hyperolius flavoviridis.

\section{Hyperolius thoracotuberculatus Ahl, 1931a: 98.}

Holotype. ZMB 36097, "Afrika (ohne genauen Fundort)" [Africa, without locality information], collector or donor unknown.

Present name. Hyperolius thoracotuberculatus Ahl, 1931a.

Remarks. Laurent (1961: 68) erroneously gives "360097" as the inventory number for the male holotype.

\section{Hyperolius togoensis Ahl, 1931a: 112.}

Holotype. ZMB 39009, "Togo (Genauerer Fundort unbekannt)" [Togo, without precise locality information], collector or donor unknown.

Present name. Hyperolius concolor (Hallowell, 1844).

Remarks. Depicted in Ahl (1931b: 390, fig. 264).

\section{Hyperolius tornieri Ahl, 1931a: 45.}

Holotype. ZMB 85833, "Ukami (Deutsch-Ost-Afrika)" [Udzungwa Mountains, Tanzania], coll. Georg Martienssen. Present name. Hyperolius tornieri Ahl, 1931.

Remarks. Drawing in Ahl (1931b: 305, fig. 179). The holotype of $H$. tornieri was sent by Martienssen in April 1898 to ZMB. For Martienssen's activities in East Africa, locality information and collecting dates, see remarks on H. pygmaeus, as well as Gvoždík et al. (2014).

\section{Hyperolius trifasciatus Ahl, 1931a: 119.}

Syntypes. ZMB 31868-31869 and ZMB 77976 (formerly part of ZMB 31869), "Grand Bassa, Liberia" [Grand Bass County, Liberia], coll. Richard Oeser.

Present name. Hyperolius fusciventris Peters, 1876.

Remarks. Depicted in Ahl (1931b: 303, fig. 278). Oeser collected the type specimens together with the holotype of $H$. oeseri in Liberia, during his journey along the West African coast in 1928, see remarks above.

\section{Hyperolius udjidjiensis Ahl, 1931a: 97.}

Holotype. ZMB 36101, “Udjidji”, [Ujiji, Kigoma Province, Tanzania], coll. Paul Hösemann. 
Paratype. ZMB 85832, "Kibwezi, Britisch-Ost-Afrika" [Kibwezi Division, Makueni County, Kenya], coll. Richard Fritz Paul Hübner [later Huebner], 5.III. 1906.

Present name. Hyperolius mariae Barbour \& Loveridge, 1928.

Remarks. Depicted in Ahl (1931b: 370, fig. 246). For Huebner's activities in (British) East Africa see remarks on Hyperolius pulchromarmoratus; for Hösemann, see remarks on $H$. argentovittis.

\section{Hyperolius unicolor Ahl, 1931a: 122.}

Holotype. ZMB 86013, "Ipiana” [Ipyana (Ipanya) on Kiwira River, at the northwestern tip of Lake Malawi, Kyela District, South Mbeya Region, Tanzania], coll. Adolf Ferdinand Stolz.

Present name. Afrixalus stuhlmanni (Pfeffer, 1893).

Remarks. For activities of Stolz in East Africa, see remarks on H. ipianae.

\section{Hyperolius variabilis Ahl, 1931a: 39.}

Holotype. ZMB 36122, "Bukoba" [Bukoba Urban District, Kagera Region, Tanzania], coll. Johann Gustav Hermann Schubotz, 15.VI.1907.

Paratypes. ZMB 77802-77813 (formerly part of ZMB 36122), "Bukoba", coll. Schubotz, 17.VI.1907; ZMB 36116, "Mohasi See", coll. Schubotz; ZMB 46518-46519, "NW-Buddu-Wald" [Minziro Forest, NW of Bukoba, Missenyi District, Kagera Region, Tanzania], coll. Schubotz, VI/1907; ZMB 46521, "Insel Kwidjwi (Kivu See)” [Idjwi (Ijwi) Island, Lake Kivu, Democratic Republic of the Congo], coll. Schubotz; ZMB 47210, "Sisse [sic], W-Niansa" [Sesse or Ssese Archipelago, Lake Victoria, Uganda], coll. Stuhlmann; ZMB 78564, "Udjidji” [Ujiji, Kigoma Province, Tanzania], coll. Dr. Hösemann; ZMB 85831, "Kagera-Ufer" [Tanzania], coll. Stuhlmann; ZMB 8587985881, "Bukoba”, coll. Dr. Eggel; ZMB 85882, "Mpororo" [Region in southern Nyagatare District, Eastern Province, Rwanda], coll. Schubotz; ZMB 85890-85892 and ZMb 91000-91002, "Bukoba", coll. Stuhlmann.

Present name. Hyperolius viridiflavus (Duméril \& Bibron, 1841).

Remarks. Ahl (1931a: 40) mentioned a series of 47 specimens from "Bukoba" including the "Type". We failed to locate 23 of these specimens. He also lists 11 additional specimens that we could not locate, as well as a second specimen from "Mohasi See", coll. Schubotz and two specimens without locality or collector information. Drawings of seven specimens showing the variation of this taxon are published by Ahl (1931b: 298, fig. 173). These have been copied from Tornier (1896, pl. 4, specimen no. 26-28 and 30-33). Another two paratypes, MCZ A-17648 and 17626, from "Bukoba" collected during the first "Deutsche Zentral-Afrika-Expedition", 1907-1908 were sent in exchange to MCZ in 1932 (Barbour and Loveridge 1946: 129).

\section{Hyperolius variegatus Peters, 1882a: 8.}

Syntypes. ZMB 10249 and 75602-75604 (formerly part of ZMB 10249), "Cabaceira" [Peninsula Cabaceira, Mossuril District, Nampula Province, Mozambique], coll. Wilhelm Carl Hartwig Peters.

Present name. Hyperolius marmoratus Rapp, 1842 [part] and Afrixalus sp. [part]

Remarks. Hyperolius variegatus was described by Peters (1882a) from an unknown number of specimens originating from "Mocambique (Cabaḉeira, Quellimane, Inhambane)". Peters (1882b: 168) mentions that he first saw small specimens of this species on bushes on the "Cabaceira" peninsula in June 1843, an adult specimen on a mulberry tree in "Quellimane" in January 1846. He also lists an observation from "Prazo [estate] Boror" in March 1846, but did not mention the locality "Inhambane" in this second publication. Tornier (1896: 145, pl. 4, figs 61, 62) mentioned and depicted the two syntypes from "Quellimane, Mozambique", both inventoried together under ZMB 4530. These could not be traced by Bauer et al. (1995: 46), nor by us. The other syntype(s) from "Inhambane" with unknown inventory number could also not be located. Laurent (1961: 67) suggested that one of the specimens under 10249 is actually a specimen of Afrixalus fornasini (Bianconi, 1849). Our examinations revealed that ZMB 10249 und ZMB 75602 are H. marmoratus, whereas ZMB 75603 and ZMB 75604 are juvenile specimens of Afrixalus. Identification on the species level was not possible for the latter two frogs.

\section{Hyperolius veithi Schick, Kielgast, Rödder, Muchai, Burger \& Lötters, 2010: 27, fig. 4 A.}

Paratype. ZMB 79542, "a flooded area in the middle of primary forest away from rivers and streams in Salonga National Park $\left(02.88^{\circ} \mathrm{S}, 20.41^{\circ} \mathrm{E}\right.$, ca. $415 \mathrm{~m}$ above sea level), Province of Bandundu, Equateur Kasaï Oriental and Occidental, Democratic Republic of the Congo", coll. Jos Kielgast, 24.-26.I.2008.

Present name. Hyperolius veithi Schick, Kielgast, Rödder, Muchai, Burger \& Lötters, 2010.

Remarks. Holotype: ZFMK 89607, “a flooded area in the middle of primary forest away from rivers and streams in Salonga National Park (02.88 S, 20.41 E, ca. 415 m above sea level), Province of Bandundu, Equateur Kasaï Oriental and Occidental, Democratic Republic of the Congo", coll. J. Kielgast, 24.I.2008. Paratypes ZFMK 8960889645 and ZMUC R771393-771412, same locality data as for the holotype, coll. J. Kielgast, 24.-26.I.2008. ZMB 79542 (formerly ZFMK 89631), was given in exchange to ZMB in October 2013 (see also Böhme 2014).

\section{Hyperolius ventrimaculatus Ahl, 1931a: 107.}

Holotype. ZMB 78563, "Vulkangebiet nord-östlich des Kivu-See's" [volcano region northeast of Lake Kivu, 
Virunga Mountains, along the border between Rwanda and the Democratic Republic of the Congo], coll. Werner Alborus von Raven, X/1907.

Present name. Hyperolius castaneus Ahl, 1931a.

Remarks. Drawing in Ahl (1931b: 381, fig. 256). The holotype was collected during the first "Deutsche Zentral-Afrika-Expedition", 1907-1908.

\section{Hyperolius vermicularis Ahl, 1931a: 24.}

Syntype. ZMB 10988, “Zanzibar” [Unguja Island, Tanzania], coll. Franz Ludwig Stuhlmann.

Present name. Hyperolius marmoratus Rapp, 1842.

Remarks. Hyperolius vermicularis Ahl is a nomen novum pro Rappia vermiculata Pfeffer, 1893 which is preoccupied by Hyperolius vermiculatus Peters, 1882a. A copy of Pfeffer's (1893, pl. 1, fig. 12) drawing is depicted by Ahl (1931b: 275, fig. 145). Pfeffer (1893) mentions two specimens (catalogue no. "352") from "Sansibar, Insel”, collected by Fülleborn on 6 August 1888. The type specimens of Rappia vermiculata are not mentioned in the herpetological type catalogues of ZMH (Hallermann 1998, 2006). A new search in ZMH collection also failed to locate the type material (Jakob Hallermann in litt. 29 July 2020). ZMB 10988 was inventoried as "Rappia vermiculata Pffr." collected by Stuhlmann, allegedly at "Quillimane". However, Tornier (1896: 141) stated that the locality is "Zanzibar" and depicted this juvenile specimen on plate 4 , figure 34 .

\section{Hyperolius vermiculatus Peters, 1882a: 8.}

Lectotype. ZMB 10050, "Malange (Angola)" [Malanje, Malanje Province, Angola], coll. Friedrich Wilhelm Alexander von Mechow.

Paralectotype. ZMB 9408, "Malange”, coll. Benedictus Ludwig Heinrich Otto Schütt.

Present name. Hyperolius angolensis Steindachner, 1867 (fide Marques et al. 2018).

Remarks. Tornier (1896, pl. 4, fig. 29) depicted the paralectotype; figure copied by Ahl (1931b: 338, fig. 211). Lectotype by subsequent designation through Laurent (1961: 88).

The Prussian explorer and topographer Major Mechow participated in the first "Loango-Expedition" from 18731875 under Paul Güssfeldt (Güssfeld et al. 1879). On a second "Kuango-Expedition" (1878-81), led by himself, he and two companions, the botanist Julius Eduard Teusz and the shipwright of the Imperial Navy Jess Bugslag (or Buslag), travelled from Luanda via Malanje (June 1888) to the confluence of the Luhemba and the Cuango River (November 1880). He returned via Malanje (February 1881) to Luanda and arrived in Berlin in August 1881 (Mechow 1882; Weidmann 1894; Heintze 2007, 2018; Teusz 2018).

From 1878 to 1879 , the expedition of engineer Schütt was carried out together with the architect Paul Gierow on behalf of the "Afrikanische Gesellschaft in Deutschland". The expedition aimed at compiling topographic reconnaissance and producing maps. They started on 4 January 1878 in Luanda and reached the lower Luachimo River (3 to 9 February 1879) via Malanje (22 February to 4 July 1878), and Quimbundo (12 November to 1 December 1878). They almost reached Mai Munene. From Quimbundo they turned back through the Lunda area and reached Luanda again via Malanje (12 to 24 May 1879) on 21 June 1879 (Heintze 2007).

Hyperolius viridiflavus

see Hyperolius flavoguttatus, Hyperolius irregularis, Hyperolius kandti, Hyperolius karissimbiensis, Hyperolius koehli, Hyperolius kwidjwiensis, Hyperolius macrodactylus, Hyperolius mohasicus, Hyperolius monticola, Hyperolius multicolor, Hyperolius oculatus, Hyperolius phrynoderma, Hyperolius punctatissimus, Hyperolius schubotzi (unlocated type specimens), Hyperolius stuhlmanni, Hyperolius variabilis, Hyperolius wettsteini.

\section{Hyperolius vittiger Peters, 1876: 122.}

Holotype. ZMB 8669, "Liberia”, coll. Heinrich Wolfgang Ludwig Dohrn.

Present name. Afrixalus vittiger (Peters, 1876).

Remarks. Peters (1876: 123) explicitly mentions the inventory number of the holotype; it was also mentioned and depicted by Tornier (1896: 144, p. 147, fig. K 50, and pl. 4, fig. 50).

\section{Hyperolius wettsteini Ahl, 1931: 70.}

Holotype. ZMB 36103, "Bukoba” [Bukoba Urban District, Kagera Region, Tanzania], coll. Johann Gustav Hermann Schubotz, 15.VI.1907.

Present name. Hyperolius viridiflavus (Duméril \& Bibron, 1841).

Remarks. Depicted in Ahl (1931b: 343, fig. 217). The holotype was collected during the first "Deutsche Zentral-Afrika-Expedition", 1907-1908.

\section{Kassina deserticola Ahl, 1930c: 280.}

Syntype. ZMB 23397 (formerly two specimens, one present in ZMB collection), "Windhuk" [Windhoek, Namibia], coll. Leonhard Scheben.

Present name. Kassina senegalensis (Duméril \& Bibron, 1841).

Remarks. Ahl (1930c: 281) exclusively designated two male specimens from "Windhuk" (ZMB 23397) as types ("Typen"). Another syntype MCZ A-17650 (formerly the second specimen under ZMB 23397) was sent in exchange to MCZ in 1932 (Barbour and Loveridge 1946: 132). Between 1909 and 1913, the German gov- 
ernment veterinarian and farmer Scheben sent several amphibian and reptile collections from the former colony "Deutsch-Südwestafrika" to ZMB. Scheben collected in "Windhuk", "Klein Nauas" and "Rehobot".

Kassina maculifer see Megalixalus maculifer.

\section{Kassina modesta Ahl, 1930c: 281.}

Holotype. ZMB 27374, "Mariannhill Natal" [Trappist Mission Station Mariannhill, ca. $16 \mathrm{~km}$ east of Durban, today eThekwini Metropolitan Municipality, KwaZulu-Natal Province, South Africa], donated by the Mariannhill Mission, leg. 11.XII.1912.

Present name. Kassina senegalensis (Duméril \& Bibron, 1841).

Remarks. The holotype was probably collected by Rev. Father Pascalis Boneberg of the Trappist Mariannhill Mission who sent several specimens to ZMB in 1913.

\section{Kassina senegalensis}

see Cystignathus argyreivittis, Kassina deserticola, Kassina modesta.

\section{Megalixalus dorsimaculatus Ahl, 1930b: 92.}

Holotype. ZMB 13696, "Magrotto bei Tanga" [plantation in southern part of Mlinga Mountains, East Usambara, Tanga Region], coll. Georg Martienssen.

Present name. Afrixalus dorsimaculatus (Ahl, 1930b).

Remarks. For Martienssen's activities in East Africa and locality information and collecting dates, see remarks on H. pygmaeus, as well as Gvoždík et al. (2014).

\section{Megalixalus maculifer Ahl, 1924: 7.}

Holotype. ZMB 26911, "Ganda Ali, Annia Galla” [south of Bia Woraba in the Ennia Galla county, East Harerge Zone, Oromia Region, Ethiopia], coll. Carl Viktor Heinrich Freiherr von Erlanger and Oskar Rudolph Neumann, 28.-29.V.1900.

Present name. Kassina maculifer (Ahl, 1924).

Remarks. From 1900 onwards, the ornithologists, mammalogists and explorers von Erlanger and Neumann undertook a two-year journey through Somaliland to the south of Ethiopia. They were accompanied by the physician and collector of botanical objects Dr. Hans Ellenbeck, the cartographer Johann Holtermüller and the taxidermist Carl Hilgert. From Zeila at the Gulf of Aden [Zeylac District, Awdal Region, Somaliland] they started their journey on 12 January 1900 and travelled via Djeldessa [Jaldessa, Sitti zone, Somali Region, Ethiopia] (3 March 1900), Harar (1 April 1900 ), Biar-Woraba [Bia-Woraba, East Harerge Zone, Oromia Region, Ethiopia] (23 May
1900), the Wabbi River [Webi Shebeli] (passage on 10 June 1900), to Addis Ababa (16 August 1900). During that journey they climbed Abu-el-Kassim [Abul Kasim, Arsi Zone, Oromia Region, Ethiopia] on 16 July 1900. From Addis Ababa Neumann went alone to Shoah [Shewa Kingdom, a region present day in Central Ethiopia] and southern Sudan, then returned to Cairo via Khartoum. Erlanger went on to Lake Turkana (Neumann 1902a, b; Erlanger 1904; Kleinschmidt 1905; Kobelt 1905). During this expedition (map with the route in Neumann 1902b) he collected thousands of zoological objects (manly insects and vertebrates), which are stored in $\mathrm{ZMB}$, SMF, NHMM, and the Walter Rothschild Zoological Museum (now the Natural History Museum at Tring; Stresemann 1947; Hildebrandt 2004).

\section{Megalixalus Stuhlmanni Pfeffer, 1893: 99.}

Syntypes. ZMB 10986 and ZMB 11015, ? "Quillimane" [Quelimane, Angoche District, Zambezia Province, Mozambique], coll. Franz Ludwig Stuhlmann.

Present name. Afrixalus stuhlmanni (Pfeffer, 1893).

Remarks. Pfeffer (1893: 100) mentions 26 specimens from "Sansibar, Insel" [Zanzibar Island], collected by Stuhlmann on 6.VIII.1888. Ahl (1930b: 96) listed under "Megalixalus stuhlmanni" two specimens from "Quillimane, Stuhlmann leg." and denotes one of them as type: "No. 1" [= ZMB 10986] "Type der Art"; the specimen "No. 2" is inventoried under ZMB 11015. These two specimens are part of a collection of amphibians and reptiles (ZMB 10983-11015), which was donated to ZMB in 1893 by ZMH in agreement with Stuhlmann. This donation contains "Doubletten" from the Stuhlmann collection, which was described by Pfeffer (1893) (see also Kirchhof et al. 2016: 181).

However, the location "Quillimane" as mentioned in the ZMB inventory catalogue does not correspond to the type locality given by Pfeffer (1893). It is unclear whether this is a transmission error of the locality information for the ZMB specimens, and "Quillimane" instead of "Sansibar" is correct. At least for the Berlin syntype of Rappia vermiculata, the locality information has been mixed up, as shown by Tornier (1896: 141, see below).

Megalixalus stuhlmanni and its type material is not mentioned in the herpetological type catalogues of ZMH (Hallermann 1998, 2006). During a renewed search, no further type material could be located (Jakob Hallermann in litt. 29 July 2020).

\section{Megalixalus uluguruensis Barbour \& Loveridge, 1928: 231.}

Paratype. ZMB 38031 (ex MCZ, previous inventory no. unknown), "Vituri, Uluguru Mtns., Tanganyika Territory" [Uluguru Mountains, Tanzania], coll. Arthur Loveridge, 30.X.1926. 
Present name. Afrixalus uluguruensis (Barbour \& Loveridge, 1928).

Remarks. Holotype: MCZ A-13311; Paratypes MCZ A-13312-13320, all from "Vituri, Uluguru Mtns.," coll. A. Loveridge, 27.31.X.1926; MCZ A-13321, from "Bumbuli, Usambara Mtns.”, coll. A. Loveridge, 14.XII.1926 and MCZ A-13368, from "Derema, Usambara Mtns.", coll. A. Loveridge, XII/1926. ZMB 38031 was donated to $\mathrm{ZMB}$ by A. Loveridge (MCZ) in the 1930 s and was inventoried in 1958.

\section{Megalixalus variabilis Ahl, 1930a: 526.}

Syntypes. ZMB 7856 and ZMB 50108-50117 (formerly part of ZMB 7856), "Nossi Faly, bei Madagascar" [Nosy Faly, SW Ambaro Bay, Ambanja District, Diana Region, Madagascar], coll. François Paul Louis Pollen.

Present name. Heterixalus variabilis (Ahl, 1930a).

Remarks. One of the 12 syntypes mentioned by Ahl (1930a: 527) could not be located. Pollen, a Dutch merchant and naturalist, undertook expeditions to Madagascar and its offshore islands in the Mozambique Channel, as well as trips to the Comoros, Mascarenes and Réunion. He collected various botanical and zoological objects between 1863 and 1866 (Pollen 1867, 1868; Rosenberg 1886). His collections are held today by the BMNH, RMNH and ZMB.

\section{Morerella cyanophthalma Rödel, Assemian, Kouamé, Tohé and Perret in Rödel, Kosuch, Grafe, Boistel, Assemian, Kouamé, Tohé, Gourène, Perret, Henle, Tafforeau, Pollet \& Veith, 2009: 29.}

Paratypes. ZMB 71566 (cleared and stained), "Banco National Park, near forest school, 05²3'.104"N, 04 ${ }^{\circ} 03.072 " W$, Ivory Coast" coll. N. Emmanuel Assemian, N'Goran G. Kouamé, Blayda Tohé and Mark-Oliver Rödel, 4.IX.2003; ZMB 71588-71590 and ZMB 73271, "Banco National Park, swampy forest with shallow puddles near river and open area near fish culture ponds, $05^{\circ} 25^{\prime} \mathrm{N}$, 04 ${ }^{\circ} 03^{\prime} \mathrm{W}$, Ivory Coast', coll. same as above, 23.IX.2004.

Present name. Morerella cyanophthalma Rödel, Assemian, Kouamé, Tohé \& Perret, 2009.

Remarks. Holotype MHNG 2131.44, "Banco National Park, $05^{\circ} 25^{\prime} \mathrm{N}, 04^{\circ} 03^{\prime} \mathrm{W}$, Ivory Coast", coll. Jean-Luc Perret, 1980. Additional paratypes as follows MHNG 2131.36-43 and MHNG 2131.45-55 same collecting data as for the holotype; SMNS 11939-11940, "Banco National Park, near forest school, 05²3'.104"N, 0403.072"W, Ivory Coast" coll. Assemian, Kouamé, Tohé and Rödel, 4.IX.2003; ZFMK 82796 same collecting data as for SMNS 11939 (Böhme 2014).

\section{Paracassina kounhiensis} see Tornierella pulchra.

\section{Rappia dombeensis Tornier, 1896: 150, pl. 4, fig. 86.}

Holotype. ZMB 6465, "Dombe” [Dombe Grande, Benguela Province, Angola], coll. José Alberto de Oliveira Anchieta, don. José Vicente Barbosa du Bocage.

Paratypes. ZMB 9173 and ZMB 74945 and 75448 (both formerly part of ZMB 9173), "Chinchoxo" [Cabinda Province, Angola], don. Africanische Gesellschaft.

Present name. Not assigned to a valid name according to Frost (2021); see below.

Remarks. As far as we are aware this nomen was not used again as valid after its introduction by Tornier (1896). It is not mentioned in recent compilations of the Angolan herpetofauna (e.g. Marques et al. 2018).

In a letter sent to Wilhelm Peters, dated 12 June 1869, Bocage announced a shipment containing 30 species of "Reptiles et Batraciens". He listed under no. 21 a "Hyperolius dombeensis n. sp. [from] Dombe". The letter is archived in the Historical Research department at the Museum für Naturkunde Berlin (ZMB). The specimens were inventoried by Peters as ZMB 6456 under the name " $\mathrm{Hy}$ perolius dombeensis Bocage" and marked as type specimen. Tornier (1896: 150) attributed the authorship to Bocage as well. However, to the best of our knowledge, Bocage never described a reed frog with the specific epithet "dombeensis". Furthermore, the name of this "new species" used by Bocage in his letter to Peters, is not accompanied by a description or drawing. Because of this, the criteria of Article 50.1.1 of the Code (ICZN 1999) are not fully met and the authorship should be attributed to Tornier (1896) who first published the name together with a short description and figure.

Beside the specimen from "Dombe" which Tornier regarded as "Type", Tornier also mentioned "identical" specimens from "Chinchoxo", ZMB 9173 [originally three specimens] and a specimen from "Port Natal" [Durban, KwaZulu-Natal Province, South Africa] in the "Hamburger Museum". The Hamburg specimen, inventoried under ZMH R16591, which we consider as paratype too, is currently determined as Hyperolius m. marmoratus (Jakob Hallermann in litt. 6 July 2020), and was collected by W. Joost on 23 April 1893. Jost also collected invertebrates at "Lourenço Marques" [Maputo, Mozambique] and "Delagoa-Bai" [Maputo Bay, Mozambique] (Wassmann 1922; Harms and Dupéré 2018; Jakob Hallermann in litt. 31 July 2020).

Our examination of the holotype revealed that it is a member of the 'sharp-nosed reed frogs', Hyperolius nasutus complex. Without genetic data, identification to species is not possible (compare Channing et al. 2013).

\section{Rappia riggenbachi Nieden, 1910a: 244, fig. 4.}

Holotype. ZMB 20435, "Banjobezirk" [Mayo-Banyo Department, Adamawa Region, Cameroon], coll. Fritz Wilhelm Riggenbach. 
Present name. Hyperolius riggenbachi (Nieden, 1910a).

Remarks. Depicted in Nieden (1910b: 61, fig. 128) and Ahl (1931b: 391, fig. 266), copied from Nieden (1910a: 245 , fig. 4). The holotype of $R$. riggenbachi was collected in January 1909 by the zoologist Riggenbach who accompanied the "Zoologisch-Botanische Kamerun-Expedition, 1908-1909" into the hinterland of Cameroon. The expedition started in Jabassi on Wuri River (15 to 16 November 1908) and went via Bamenda (17 December), the Bansso Mountains (29 December), Banjo (12 January 1909), the Genderu Mountains (20 February to 3 March), Gorua (13 to 23 April), the Lagdo Mountains (26 June) to Garua (11 to 20 August 1909). A map and itinerary of the expedition can be found in Reichenow (1911).

\section{Tornierella pulchra Ahl, 1924: 10.}

Syntypes. ZMB 26917, “Garamulata, ca. $2800 \mathrm{~m}$ hoch, im Wald" [Gara Muleta Mountain, East Harerge Zone, Oromia Region, Ethiopia, ca. $2800 \mathrm{~m}$ a.s.1., in forest], coll. Carl Viktor Heinrich Freiherr von Erlanger and Oskar Rudolph Neumann, 31.III.1900, and ZMB 26918, "Somaliland" [Eastern Oromia Region, Ethiopia], same collectors as above.

Present name. Paracassina kounhiensis (Mocquard, 1905).

Remarks. For information on the expedition period and route of Erlanger and Neumann, see remarks on Megalixalus maculifer.

Unlocated type specimens

\section{Hyperolius bergeri Ahl, 1931a: 73.}

Holotype. ZMB unknown; "Guaso Narok (Englisch-Ostafrika)" [Uaso Narok, Nyandarua North District Laikipia County, Kenya]; coll. Arthur Berger.

Present name. Hyperolius glandicolor Peters, 1878. Remarks. Drawing in Ahl (1931b: 347, fig. 221).

\section{Hyperolius bicolor Ahl, 1931: 129.}

Holotype. ZMB unknown; "Farenda [sic] Bango, Loanda", [Fazenda Bango, Cuanza Norte Province, Angola]; coll. Lieutenant Karl May, 1903.

Present name. Hyperolius bicolor Ahl, 1931.

Remarks. Drawing in Ahl, 1931b: 414, fig. 287.

\section{Hyperolius buchholzi Ahl, 1931a: 56.}

Holotype. ZMB unknown, "Accra" [Ghana], coll. Reinhold Wilhelm Buchholz.

Present name. Hyperolius guttulatus Günther, 1858.
Remarks. Depicted in Ahl (1931b: 320, fig. 194).

\section{Hyperolius guttolineatus Ahl, 1931a: 57.}

Holotype. ZMB unknown, "Deutsch-Ost-Afrika (näherer Fundort unbekannt)" [German East Africa, exact locality unknown], coll. Ferdinand Uhl.

Present name. Hyperolius marmoratus Rapp, 1842.

Remarks. Drawing in Ahl (1931b: 321, fig. 195). Chief medical officer Dr. Uhl carried out his colonial service at the "Schutztruppe" from 1896 to 1901. In January 1900, he was commanded to Langenburg [Lumbira, Mbeya Region, Tanzania] to replace Stuhlmann (Stuhlmann 1906).

\section{Hyperolius bituberculatus Ahl, 1931a: 27.}

Holotype. ZMB unknown, "Mohasi-See, Ruanda" [Lake Mohasi, Rwanda], coll. Johann Gustav Hermann Schubotz, VII/1907.

Present name. Hyperolius kivuensis Ahl, 1931a.

Remarks. Drawing in Ahl (1931b: 281, fig. 152). The holotype was collected during the first "Deutsche Zentral-Afrika-Expedition”, 1907-1908.

\section{Hyperolius moseri Ahl, 1931a: 50.}

Holotype. ZMB unknown, "Misahöhe, Togo", [Missahomé, Agou Prefecture, Plateau Region, Togo], coll. Ernst Richard Reinhold Baumann.

Present name. Hyperolius concolor (Hallowell, 1844).

Remarks. Depicted in Ahl (1931b: 311, fig. 186).

\section{Hyperolius renschi Ahl, 1931a: 115.}

Holotype. ZMB unknown, "Zanzibar" [Unguja Island, Tanzania], coll. Oscar Rudolph Neumann.

Present name. Hyperolius mariae Barbour \& Loveridge, 1928.

\section{Hyperolius schubotzi Ahl, 1931a: 63.}

Holotype. ZMB unknown, "Kissenji” [on the northeast shore of Lake Kivu close to the border of Democratic Republic of the Congo, Rwanda], coll. Johann Gustav Hermann Schubotz, X/1907.

Present name. Hyperolius viridiflavus (Duméril \& Bibron, 1841).

Remarks. Depicted in Ahl (1931b: 329, fig. 202). The holotype was collected during the first "Deutsche Zentral-Afrika-Expedition", 1907-1908. 
Megalixalus laevis Ahl, 1930b: 93.

Holotype. ZMB unknown, "Kamerun" [Cameroon], coll. Leopold Fritz Wilhelm Edmund Conradt, 8.V.1896.

Present name. Afrixalus laevis (Ahl, 1930b).

Remarks. The German colonial officer and planter Conradt was stationed at "Lolodorf" [Océan Division, South Province, Cameroon] and worked as station manager at "Johann Albrechtshöhe" [southeast of Lake Barombi Mbo, near Kumba, Southwest Region, Cameroon] from 1895 to 1899 (Schnee 1920a). In February 1897, a shipment containing amphibians and reptiles collected by him at "Albrechtshöhe, Kamerun" arrived at ZMB. See also remarks on Hyperolius laticeps for Conradt's activities in Togo.

Specimens erroneously marked as types in ZMB inventory catalogues

Hyla horstockii Schlegel, 1837: 24, footnote 1.

ZMB 3064 (originally 3 specimens), "Cap" [Cape Province, South Africa], coll. Georg Ludwig Engelhard Krebs.

Present name. Hyperolius horstocki (Schlegel, 1837).

Remarks. The original catalogue entry of ZMB 3064 made by Martin Hinrich Carl Lichtenstein around 1858 is marked as type of "Hyla Horstockii Schlegel*" from "Cap", collected by "Krebs". The original entry was later crossed out and changed to "[Hyperolius] modestus, Boutry, Goldküste, [coll.] Pel, [don.] Schlegel" by the same. With this "correction" Lichtenstein probably was referring to Eucnemis modestus Lichtenstein \& Martens, 1856 (p. 36, nomen nudum). Likely following the new generic allocation proposed by Tschudi (1838: 35), Lichtenstein and Martens (1856: 36) listed a specimen under the name "Eucnemis Horstockii Schleg." (= Hyperolius horstockii) with the locality given as "Cap" but without mentioning collector or donor. We reviewed the documents archived in the Historical Research department of the ZMB concerning the correspondence and exchange files of Lichtenstein with Heinrich Boie, Hermann Schlegel and Coenraad Jacob Temminck from the Rijksmuseum van Natuurlijke Historie in Leiden. We could not find any evidence that specimens of the original type series of Hyla horstockii were given to the ZMB. Most probably the specimens under ZMB 3064 (as originally indicated) were collected by the German apothecary and collector of natural history objects Krebs who regularly sent specimens to the ZMB collection during the first half of the $19^{\text {th }}$ century (Bauer 2000, 2004) and then were erroneously marked as types.

"Hyperolius callodermatus" attributed to "Ahl" according to ZMB inventory catalogue.

ZMB 36096, “Ukami” [Udzungwa Mountains, Tanzania], coll. Georg Martienssen.

Status. Unpublished name.
Present determination. A Hyperolius which, due to the usual preservation state of these frogs - showing few diagnostic characters - cannot be assigned with certainty to any species.

"Hyperolius cinctopunctatus" attributed to "Ahl" according to ZMB inventory catalogue.

ZMB 31663, "Kibwezi” [Makueni County, Kenya], coll. Georg Richard Otto Scheffler.

Status. Unpublished name.

Present determination. Hyperolius viridiflavus ferniquei fide Schiøtz (1975).

\section{"Hyperolius janenschi" attributed to "Ahl" according} to $\mathrm{ZMB}$ inventory catalogue.

ZMB 36118 and 36119 from Rugwe [Rungwe village, Mbeya Region, Tanzania], and ZMB 36120 and 77033 from "S' ongwe" [Songwe, at the border to Malawi on the northwestern tip of Lake Malawi, Kyela District, South Mbeya Region, Tanzania], all coll. Friedrich Georg Hans Heinrich Fülleborn.

Status. Unpublished name.

Present determination. Most likely Hyperolius substriatus Ahl, 1931a.

\section{"Hyperolius nairobiensis" attributed to "Ahl" accord-} ing to ZMB inventory catalogue.

ZMB 36107 from "Nairobi" [Kenya], coll. Felice Thomas.

Status. Unpublished name.

Present determination. Hyperolius viridiflavus ferniquei fide Schiøtz (1975).

"Rappia femoralis" attributed to "Matschie" according to ZMB inventory catalogue.

ZMB 11088, "Borombi” [Colonial station, from 1895 under the name "Johann-Albrechtshöhe", southeast of Lake Barombi Mbo, near Kumba, Southwest Region, Cameroon], coll. Captain Karl Ludwig Zeuner.

Status. Unpublished name.

Present determination. unknown, specimen not located.

"Rappia ocularis" attributed to "Matschie" according to ZMB inventory catalogue.

ZMB 11131, "Kribi” [Océan Department, South Province, Cameroon], coll. Major Curt Ernst Morgen.

Status. Unpublished name.

Present determination. unknown, specimen not located.

\section{Acknowledgements}

We are grateful to Annemarie Ohler (MNHN), Alexander Kupfer (SMNS), Linda Mogk (SMF), Morris Flecks 
(ZFMK) and Jakob Hallermann (ZMH) for information on the availability of the publications published by Ahl 1931. Jakob Hallermann also provided information on the type specimens of the reed frogs described by J. G. Pfeffer and Silke Schweiger (NMW) sent us information on the amphibians and reptiles collected by R. Grauer kept in the NMW collection. Vasco Galante (Gorongosa National Park, Mozambique) provided some information concerning Mozambican localities. We are thankful to former and present staff of the ZMB library, Martina Rißberger, Hand-Ulrich Raake, Maria Xylaki, Vivien Bauer and the Department of Historical Research at ZMB, Sandra Miehlbradt, Sabine Hackethal, Hannelore Landsberg for procuring rare literature and access to archive material. We are grateful to Aaron Bauer, David C. Blackburn and Alan Channing for their thorough reading of a previous version of the manuscript. Their comments and constructive critique improved our paper!

\section{References}

Adler K (2007) Ernst Ahl (1898-1945). Contributions to the history of herpetology (Vol. 2) (Contributions to Herpetology 21). Society for the Study of Amphibians and Reptiles, Oxford, 156-157.

Ahl E (1924) Über eine Froschsammlung aus Nordost-Afrika und Arabien. Mitteilungen aus dem Zoologischen Museum in Berlin 11: 1-12. https://doi.org/10.1002/mmnz.4830110102

Ahl E (1929) Zur Kenntnis der Baumfroschgattung Chiromantis Peters. Zoologischer Anzeiger 80(1/2): 27-37.

Ahl E (1930a) Zur Kenntnis der Megalixalus-Arten Madagascars und der umliegenden Inseln (Amphib., Anur.). Mitteilungen aus dem Zoologischen Museum in Berlin 16: 523-529.

Ahl E (1930b) Ueber die afrikanischen Arten der Baumfroschgattung Megalixalus. Sitzungsberichte der Gesellschaft Naturforschender Freunde zu Berlin 1930: 89-102.

Ahl E (1930c) Zur Kenntnis der afrikanischen Froschgattung Kassina Girard. Zoologischer Anzeiger 88(9/10): 277-283.

Ahl E (1930d) Zur Kenntnis der madagassischen Arten der Baumfroschgattung Hyperolius. Zoologischer Anzeiger 90(3/4): 65-68.

Ahl E (1931a) Zur Systematik der afrikanischen Arten der Baumfroschgattung Hyperolius (Amph. Anur.). Mitteilungen aus dem Zoologischen Museum in Berlin 17(1): 1-132.

Ahl E (1931b) Amphibia, Anura III, Polypedatidae. In: Hesse R (Ed.) Das Tierreich. Eine Zusammenstellung und Kennzeichnung der rezenten Tierformen. 55. Lieferung. Walter de Gruyter \& Co. Berlin und Leipzig, 477 pp. [+(1-2)]. https://doi.org/10.1515/9783111625430-fm

Ahl E (1931c) Beschreibung zweier neuer Baumfrösche der Gattung Chiromantis. Sitzungsberichte der Gesellschaft Naturforschender Freunde zu Berlin 1931: 211-216.

Amiet J-L (2012) Les Rainettes du Cameroun (Amphibiens Anoures). La Nef des Livres, Saint-Nazaire, France, 591 pp.

Anonymous (1903) Bericht über das Zoologische Museum zu Berlin im Rechnungsjahr 1902. Buchdruckerei des Waisenhauses, Halle a. S.: $1-30$.

Anonymous (1904) Bericht über das Zoologische Museum zu Berlin im Rechnungsjahr 1903. - Buchdruckerei des Waisenhauses, Halle a. S.: $1-30$.
Bamps P (1975) Itinéraire et lieux de récolte de Milbraed lors de sa première expedition en Afrique centrale (1907-1908). Bulletin du Jardin botanique National de Belgique/Bulletin van de Nationale Plantentuin van België 45(1/2): 159-179. https://doi. org/10.2307/3667595

Baptista N, Conradie W, Vaz Pinto P, Branch WR (2019) The amphibians of Angola: early studies and curent state of knowledge. In: Huntley BJ, Russo V, Lages F, Ferrand N (Eds) Biodiversity of Angola. Springer, Cham, 243-281. https://doi.org/10.1007/978-3-03003083-4_12

Barbour T, Loveridge A (1928) A comparative study of the herpetological faunae of the Uluguru and Usambara Mountains, Tanganyika Territory with descriptions of new species. Memoirs of the Museum of Comparative Zoology. Cambridge, Massachusetts 50(2): 87-265. https://www.biodiversitylibrary.org/page/4370098

Barbour T, Loveridge A (1946) First supplement to typical reptiles and amphibians. Bulletin of the Museum of Comparative Zoology 96(2): 58-214.

Bauer AM (2000) Comments on the types and type localities of South African reptiles collected by Heinrich Bergius and Ludwig Krebs. African Journal of Herpetology 49(1): 53-60. https://doi.org/10.108 0/21564574.2000.9650016

Bauer AM (2004) Early German herpetological observations and explorations in southern Africa, with special reference to the Zoological Museum of Berlin. Bonner zoologische Beiträge 52(3/4): 193-214.

Bauer AM, Good DA, Günther R (1993) An annotated type catalogue of the caecilians and salamanders (Amphibia: Gymnophiona and Caudata) in the Zoological Museum, Berlin. Mitteilungen aus dem Zoologischen Museum in Berlin 69(2): 285-306. https://doi. org/10.1002/mmnz.19930690208

Bauer AM, Günther R, Klipfel M (1995) Synopsis of taxa. In: Bauer AM, Günther R, Klipfel M (Eds) Herpetological Contributions of W.C.H. Peters (1815-1883). Society for the Study of Amphibians and Reptiles, Oxford, 39-81.

Bauer AM, Günther R, Robeck HE (1996) An annotated type catalogue of the hemisoid, microhylid, myobatrachid, pelobatid and pipid frogs in the Zoological Museum, Berlin (Amphibia: Anura: Hemisotidae, Microhylidae, Myobatrachidae, Pelobatidae and Pipidae). Mitteilungen aus dem Zoologischen Museum in Berlin 72(2): 259-275. https://doi.org/10.1002/mmnz.19960720205

Berger A (1924) Der heilige Nil. Wegweiser-Verlag, Berlin, 333 pp. [+ (1) pp., map.]

Berger A (1942) So sah ich die Welt! Lebenserinnerungen eines Forschungsreisenden. Buchmeister Verlag, Berlin, 201 pp.

Bianconi GG (1849 “1848”) Lettera al Dottore Filippo De-Filippi, Professore di Zoologia a Torino, sopra alcune nuove specie di Rettili del Mozambico. Nuovi Annali delle Scienze Naturali, Serie 2, Bologna 10: 106-109.

Bindseil R (1988) Ruanda und Deutschland seit den Tagen Richard Kandts. Begegnungen und gemeinsame Wegstrecken. Historischer Abriß der deutsch-ruandischen Beziehungen mit einer biographischen Würdigung des einstigen deutschen kaiserlichen Residenten. Dietrich Reimer, Berlin, 290 pp. [bilingual German/French].

Bindseil R (2008) Franz Stuhlmann (1863-1928). Beiträge zur deutschen Kolonialgeschichte Band 12. Projekte-Verlag Cornelius GmbH, Halle/Saale, 78 pp.

Bocage JVB du (1866) Reptiles nouveaux ou peu recueillis dans les possessions portugaises d l'Afrique occidentale, qui se trouvent au 
Muséum de Lisbonne. Jornal de Sciências, Mathemáticas, Physicas e Naturaes 1: 57-78.

Bocage JVB du (1868 «1867») Batraciens nouveaux de l'Afrique occidentale (Loanda et Benguella). Proceedings of the Zoological Society of London 1867: 843-846.

Böhme W (2014) Type catalogue. In: Böhme W (Ed.) Herpetology in Bonn. Mertensiella 21: 85-200.

Boettger O (1881) Diagnoses reptilium et batrachiorum novorum ab ill. Antonio Stumpff, in Insula Nossi-Bé Madagascariensi lectorum. Zoologischer Anzeiger 4: 358-361.

Boulenger GA (1899) Descriptions of new batrachians in the collection of the British Museum (Natural History). The Annals and Magazine of Natural History Series 7, 3: 273-277. https://doi. org/10.1080/00222939908678122

Brauer A (1910) Das zoologische Museum. In: Lenz M (ed.). Geschichte der königlichen Friedrich-Wilhelms-Universität zu Berlin. Dritter Band. Buchhandlung des Waisenhauses, Halle an der Saale, 372-389.

Ceríaco LMP, Marques MP, André I, Afonso E, Blackburn DC, Bauer AM (2020) Illustrated type catalogue of the "lost" herpetological collections of Museo du Dundo, Angola. Bulletin of the Museum of Comparative Zoology 162(7): 379-440. https://doi. org/10.3099/0027-4100-162.7.379

Channing A, Hillers A, Lötters S, Rödel M-O, Schick S, Conradie W, Rödder D, Mercurio V, Wagner P, Dehling JM, Du Preez LH, Kielgast J, Burger M (2013) Taxonomy of the super-cryptic Hyperolius nasutus group of long reed frogs of Africa (Anura: Hyperoliidae), with descriptions of six new species. Zootaxa 3620(3): 301-350. https://doi.org/10.11646/zootaxa.3620.3.1

Channing A, Howell KM (2006) Amphibians of East Africa. Cornell University Press, Ithaca, 418 pp. [24 pls.]

Channing A, Rödel M-O (2019) Field guide to the frogs and other amphibians of Africa. Struik Nature, Cape Town, 408 pp.

Conradie W, Branch WR, Watson G (2015) Type specimens in the Port Elizabeth Museum, South Africa, including the historically important Albany Museum collection. Part 1: Amphibians. Zootaxa 3936(1): 42-70. https://doi.org/10.11646/zootaxa.3936.1.2

Conradt L (1896) Das Hinterland der deutschen Kolonie Togo. Dr. A. Petermanns Mitteilungen aus Justus Perthes' Geographischer Anstalt 42: 11-20. [29-33.]

Cope ED (1861 “1860”) Descriptions of new species of the reptilian genera Hyperolius, Liuperus and Tropidodipsas. Proceedings of the Academy of Natural Sciences of Philadelphia 12 [1860]: 517-518.

Danckelmann [A] (1891) Bemerkungen zu Dr. Stuhlmann's Routenkarte von Bukoba nach Karagwe. Mitteilungen von Forschungsreisenden und Gelehrten aus den deutschen Schutzgebieten 4: 221-228. [map.]

Danckelmann [A] (1892) Vorläufige Mitteilungen über die wissenschaftlichen Gesamtergebnisse der Expedition Emin Pascha's 1890 bis 1892. Mitteilungen von Forschungsreisenden und Gelehrten aus den deutschen Schutzgebieten 5: 248-251.

Danckelmann [A] (1895) E. Baumanns zoologische Sammlungen im Togogebiete. Mitteilungen von Forschungsreisenden und Gelehrten aus den deutschen Schutzgebieten 8: 271-273.

Danckelmann [A] (1901) Bericht über die Expedition des Hauptmann v. Schimmelpfennig von Ngutte II nach Yabassi. Mitteilungen von Forschungsreisenden und Gelehrten aus den deutschen Schutzgebieten 14: 144-166. [map.]

Decken CC [bearbeitet von O. Kersten] (1869) Baron Carl Claus von der Decken's Reisen in Ost-Afrika in den Jahren 1859-1865. Dritter
Band: Wissenschaftliche Ergebnisse: Erste Abtheilung: Säugethiere, Vögel, Amphibien, Crustaceen, Mollusken und Echinodermen. C. F. Winter, Leipzig und Heidelberg, 169 pp. [35 pls.]

Dehling JM (2012) An African glass frog: A new Hyperolius species (Anura: Hyperoliidae) from Nyungwe National Park, southern Rwanda. Zootaxa 3391: 52-64. https://doi.org/10.11646/zootaxa.3391.1.4

Dinslage S [Ed.] (2015) Mein Leben [G. T. Tessmann]. Tagebuch in 12 Bänden. Teil 3, Abschnitt IV-V. Lübecker Beiträge zur Ethnologie 4: $1-544$

Dinslage S, Templin B [Eds] (2012) Mein Leben [G. T. Tessmann]. Tagebuch in 12 Bänden. Teil 1, Abschnitt I-II. Lübecker Beiträge zur Ethnologie 2: 1-477.

Documents kept in the Department of Historical Research (Historische Arbeitsstelle) of the Museum für Naturkunde Berlin and consulted ZMB register (Unpublished source) Documents kept in the Department of Historical Research (Historische Arbeitsstelle) of the Museum für Naturkunde Berlin and consulted ZMB register (accession catalogues): Lichtenstein, H. M. Eingangsjournal über den Zugang von Naturalien des Königlichen Zoologischen Museums zu Berlin von 1816 bis 1857 (2 vols.); Zoologisches Museum, Signature S II, "Barboza du Bocage"; Zoologisches Museum, Signature S II, "Brühl, Ludwig"; Zoologisches Museum, Signature S III, "Fülleborn, F."; Zoologisches Museum, Signature S III, "Küttner, Otto, Dr.”; Zoologisches Museum, Signature S II "Museum Hamburg"; Zoologisches Museum, Signature S II "Martienssen, G."; Zoologisches Museum, Signature S II, "Mechow, v. - Major"; Zoologisches Museum, Signature S III, "Rolle, H."; Zoologisches Museum, Signature S II "Stuhlmann, F."; Zoologisches Museum, Signature S I "Temminck, C. J." (incl. correspondence of H. Schlegel and H. Boie to H. Lichtenstein); Zoologisches Museum, Signature S II, “Thomas, Fe.”.

Drewes RC (1997) A new species of treefrog from the Serengeti National Park, Tanzania (Anura: Hyperoliidae: Hyperolius). Proceedings of the California Academy of Sciences 49: 439-446.

Dubois A, Ohler A, Pyron A (2021) New concepts and methods for phylogenetic taxonomy and nomenclature in zoology, exemplified by a new ranked cladonomy of recent amphibians (Lissamphibia). Megataxa 5(1): 1-738. https://doi.org/10.11646/megataxa.5.1.1

Duméril AMC, Bibron G (1841) Erpétologie Genérale ou Histoire Naturelle Complète des Reptiles (Vol. 8). Librarie Enclyclopedique de Roret, Paris (4), 792 pp.

Engler A (1902) Berichte über die botanischen Ergebnisse der Nyassa-See- und Kinga-Gebirgs-Expedition der Hermann- und Elisegeb. Heckmann-Wetzel-Stiftung. IV. Die von W. Goetze am Rukwa-See und Nyassa-See sowie in den zwischen beiden Seen gelegenen Gebrirgsländern, insbesondere dem Kinga-Gebirge gesammelten Pflanzen, nebst einigen Nachträgen (durch * bezeichnet) zu Bericht III. Botanische Jahrbücher für Systematik, Pflanzengeschichte und Pflanzengeographie 30(2): 239-288; 30(3-4): 289-445.

Erlanger C von (1904) Bericht über meine Expedition in Nordost-Afrika in den Jahren 1899-1901. Zeitschrift der Gesellschaft für Erdkunde zu Berlin 2: 89-117.

Ernst R, Kehlmaier C, Baptista NL, Pinto PV, Branquima MF, Dewynter M, Fouquet A, Ohler A, Schmitz A (2021) Filling the gaps: The mitogenomes of Afrotropical Egg-guarding Frogs based on historical type material and a re-assessment of the nomenclatural status of Alexteroon Perret, 1988 (Hyperoliidae). Zoologischer Anzeiger 293: 215-224. https://doi.org/10.1016/j.jcz.2021.06.002 
Fecitt H (2011) Medo and Mbalama Hill, Portuguese East Africa $-12^{\text {th }}$ to $24^{\text {th }}$ April 1918. Nyasaland Battalions of the King's African Rifles in fierce combat with a withdrawn German Schutztruppe. The Society of Malawi Journal 64(2): 23-29.

Fitzner R (1901) Deutsches Kolonial-Handbuch. Nach amtlichen Quellen bearbeitet. Band 1. Hermann Paetel, Berlin, 431 pp. [2 $2^{\text {nd }}$ edition].

Frahm J-P, Eggers J (2001) Lexikon Deutschsprachiger Bryologen. Self-published, Bonn, 672 pp.

Frétey T, Dubois A, Ohler A (2014) The status of the nomen Hyperolius guttatus Peters, 1875 (Amphibia: Anura) and allied nomina. Alytes 30: 11-26.

Friederichs K (1919) Beobachtungen über einige solitäre Wespen in Madagaskar. Mitteilungen aus dem Zoologischen Museum in Berlin 9(1): 46-50. [pl. 2-3.]

Frost DR [Ed.] (1985) Amphibian species of the world. A taxonomic and geographical reference. Allen Press and The Association of Systamatic Collections, Lawrence, $732 \mathrm{pp}$.

Frost DR (2021) Amphibian Species of the World: an Online Reference. Version 6.1 (Date of access). Electronic Database accessible at https://amphibiansoftheworld.amnh.org/index.php [American Museum of Natural History, New York, USA (last accessed March 2021)]

Fülleborn F (1900a) Über Untersuchungen im Nyassa-See und in den Seen im nördlichen Nyassa-Land. Verhandelungen der Gesellschaft für Erdkunde zu Berlin 6: 332-338. [pl. 5-6.]

Fülleborn F (1900b) Reisen im Nyassa-Gebiet. Verhandelungen der Gesellschaft für Erdkunde zu Berlin 7: 371-384.

Fülleborn F (1906) Das Deutsche Njassa- und Ruwuma-Gebiet, Land und Leute, nebst Bemerkungen über die Schire-Länder. Mit Benutzung von Ergebnissen der Niassa- und Kingagebirge-Expedition der Herrmann und Elise geb. Heckmann Wetzel-Stiftung verfasst. Dietrich Reimer, Berlin, 636 pp.

Futterer K (1895) Afrika in seiner Bedeutung für die Goldproduktion in Vergangenheit, Gegenwart und Zukunft. Dietrich Reimer, Berlin, 191 pp. [map.]

Gassó Miracle ME, van den Hoeck Ostende LW, Arntzen JW (2007) Type specimens of amphibians in the National Museum of Natural History, Leiden, The Netherlands. Zootaxa 1482: 25-68. https://doi. org/10.11646/zootaxa.1482.1.2

Gemel R, Gassner G, Schweiger S (2019) Katalog der Typen der Herpetologischen Sammlung des Naturhistorischen Museums Wien 2018. Annalen des Naturhistorischen Museums in Wien [B] 212: 33-248.

Glaw F, Franzen M (2006) Type catalogue of amphibians in the Zoologische Staatssammlung München. Spixiana 29(2): 153-192.

Glaw F, Vences M (1992) A fieldguide to the amphibians and reptiles of Madagascar. M. Vences \& F. Glaw Verlag, Cologne, 331 pp.

Glaw F, Vences M (1993) Zur Bioakustik, Biologie und Systematik der Gattung Heterixalus aus Madagaskar (Anura: Hyperoliidae). Salamandra 29(3-4): 212-230.

Grandidier A (1872) Description de quelques reptiles nouveaux découverts à Madagascar en 1870. Annales des Sciences Naturelles, Zoologie et Biologie Animale, Paris, Serie 5, 15: 6-11.

Graß [K] (1904) Forststatistik für die Waldungen des Rufiyideltas, angefangen im Jahre 1902. Berichte über Land- und Forstwirtschaft vom Kaiserlichen Gouvernement von Deutsch Ostafrika Dar-esSalam 2(3): 165-196. [pl. 5.]

Grimpe G (1931) Julius Vosseler zum 70. Geburtstage. Der Zoologische Garten (N. F.) 5(10/12): 313-317.
Günther A[CLG] (1858) Neue Batrachier in der Sammlung des Britischen Museums. Archiv für Naturgeschichte, Berlin 24(1): 319-328. https://www.biodiversitylibrary.org/page/7459956

Günther A[CLG] (1864) Report on a collection of reptiles and fishes made by Dr. Kirk in the Zambesi and Nyassa regions. Proceedings of the Zoological Society of London 1864: 303-314. [pl. 26-27.]

Günther A[CLG] (1865 “1864”) Descriptions of new species of batrachians from West Africa. Proceedings of the Zoological Society of London 1864: 479-482.

Günther A[CLG] [Ed]) (1906) The history of the collections contained in the natural history departments of the British Museum (Vol. II). Trustees of the British Museum, London, (4), 782 pp.

Günther R, Bischoff W (2018) Friedrich Erich Gottlieb Nieden (18831952). In: Bischoff W (Ed.) Die Geschichte der Herpetologie und Terrarienkunde im deutschsprachigen Raum II. Mertensiella 27: 286-290.

Güssfeldt P, Falkenstein J, Pechuel-Loesche E (1879) Die Loango-Expedition ausgesandt von der Deutschen Gesellschaft zur Erforschung Aequatorial-Africas 1873-1876. Paul Frohberg, Leipzig, (5), 304 pp. https://doi.org/10.5479/sil.372826.39088006097414

Gvoždík V, Tillack F, Menegon M, Loader SP (2014) The satus of Leptopelis barbouri Ahl, 1929 and eleven other nomina of the current tree-frog genus Leptopelis (Arthroleptidae) described from East Africa, with redescription of Leptopelis grandiceps Ahl, 1929. Zootaxa 3793(1): 165-187. https://doi.org/10.11646/zootaxa.3793.1.8

Hafeneder R (2008) Deutsche Kolonialkartographie 1884-1919. Dissertation, Fakultät für Bauingenieur- und Vermessungswesen der Universität der Bundeswehr München, 200 pp. [+ (3) + 38 pp.]

Hafeneder R (2010) Vermessung, Aufnahme und Kartierung der deutschen Kolonien - aus der Sicht eines Topographen im Jahr 1921. R. Hafeneder, Bonn, (3), 74 pp. [+ (1) pp.]

Hallermann J (1998) Annotated catalogue of the type specimens of the herpetological collection in the Zoological Museum of the University of Hamburg. Mitteilungen aus dem Hamburgischen Zoologischen Museum und Institut 95: 197-223.

Hallermann J (2006) Additions to the catalogue of the type specimens of the herpetological collection in the Zoological Museum of the University of Hamburg. Mitteilungen aus dem Hamburgischen Zoologischen Museum und Institut 103: 137-147.

Hallowell E (1844) Descriptions of new species of African reptiles. Proceedings of the Academy of Natural Sciences of Philadelphia 2: 58-62.

Hand F (1848) Gelehrte Gesellschaften. Gesellschaft naturforschender Freunde in Berlin. Neue Jenaische Allgemeine Literatur-Zeitung, 7. Jahrgang, 168: 669 [brief outline of Peters' journey to Mozambique].

Harms D, Dupérré N (2018) An annotated type catalogue of the camel spiders (Arachnida: Solifugae) held in the Zoological Museum Hamburg. Zootaxa 4375(1): 1-58. https://doi.org/10.11646/zootaxa.4375.1.1

Haupt W (1988) Die deutsche Schutztruppe 1889/1918. Auftrag und Geschichte. Edition Dörfler, Nebel Verlag, Utting, 163 pp.

Heinersdorff C (1880) Reinhold Buchholz' Reisen in West-Afrika nach seinen hinterlassenen Tagebüchern und Briefen nebst einem Lebensabriss des Verstorbenen. F. A. Brockhaus, Leipzig, [viii + (2)] 263 pp. [map.]

Heintze B (2007) Deutsche Forschungsreisende in Angola. Ethnographische Aneignungen zwischen Sklavenhandel, Kolonialismus und Wissenschaft. Kurzbiographien mit Selbstzeugnissen und Textbeispielen. Otto Lembeck, Frankfurt am Main, 459 pp. [2 maps.] 
Heintze B [Ed.] (2018) Das Tagebuch Alexander v. Mechows über seine Expedition an den Kwango (Angola) (1880-1881). Beilage I zu Beatrix Heintze: Ein preußischer Major im Herzen Afrikas. Alexander v. Mechows Expeditionstagebuch (1880-1881) und sein Projekt einer ersten deutschen Kolonie. Dietrich Reimer, Berlin (Studien zur Kulturkunde 133), 950 pp. [map.]

Herrmann H-J (1989) Die Amphibientypen des Zoologischen Museums Greifswald. Veröffentlichungen des Naturhistorischen Museums Schleusingen 4: 13-14.

Heß W (1902) Baumann, Ernst. In: Historische Commission bei der königl. Akademie der Wissenschaften (Ed.) Allgemeine Deutsche Biographie, Band 46, Nachträge bis 1899. Duncker und Humboldt, Leipzig, 254-255.

Hildebrand U (2004) Carlo von Erlanger (Ingelheim) und die Präparatesammlung aus Ingelheim im Naturhistorischen Museum Mainz - Sammlungsbericht. Mainzer naturwissenschaftliches Archiv 42: 267-278.

Hildebrandt JM (1877) [Über seine Reisen in Ost-Afrika]. Verhandlungen der Gesellschaft für Erdkunde zu Berlin 4: 284-295.

Hösemann F [sic] (1897) [Anthropologische Aufnahmen von Eingeborenen aus Ujiji]. Zeitschrift für Ethnologie Jahrgang 29: 410-425.

Hoffmann F (2007) Okkupation und Militärverwaltung in Kamerun. Etablierung und Institutionalisierung des kolonialen Gewaltmonopols. Teil II, Die kaiserliche Schutztruppe und ihr Offizierkorps. $\mathrm{Cu}$ villier Verlag, Göttingen, 266 pp.

Holthuis LB (1968) Biografische Notities betreffende Verzamelaars voor het Rijksmuseum van Natuurlijke Historie te Leiden. I. Hendrik Severinus Pel (1818-1876). Zoologische Bijdragen 10: 3-32.

[ICZN] International Commisssion on Zoological Nomenclature (1999) International code of zoological nomenclature. The International Trust for Zoological Nomenclature, London, 306 pp. [4 $4^{\text {th }}$ edition].

Jones A, Albert P, Reimers A, Schröter A (2000) Afrikabestände im Unitätsarchiv der Herrnhuter Brüdergemeinde II. Die in Afrika tätigen Geschwister, Literaturverzeichnis. - University of Leipzig Papers on Africa, Mission Archives 11: 6-90.

Kandt [R] (1899) Bericht [...] über Reisen [...] am Kivusee. Mitteilungen von Forschungsreisenden und Gelehrten aus den deutschen Schutzgebieten 12: 235-237. [map.]

Kandt R (1900) Bericht über meine Reisen und gesamte Thätigkeit in Deutsch-Ostafrika. Mitteilungen von Forschungsreisenden und Gelehrten aus den deutschen Schutzgebieten 13: 240-264.

Kandt R (1921) Caput Nili. Eine empfindsame Reise zu den Quellen des Nils. Dietrich Reimer, Berlin, 538 pp. [5 ${ }^{\text {th }}$ edition].

Kirchhof S, Mahlow K, Tillack F (2016) The identity of Stenorhabdium temporale Werner, 1909 (Serpentes: Colubroidea). Vertebrate Zoology 66(2): 179-190.

Kleinschmidt O (1905) Carlo Freiherr von Erlanger $\uparrow$. Journal für Ornithologie 53: 34-41. https://doi.org/10.1007/BF02089386

Kobelt W (1905) Carlo von Erlanger $\uparrow$. Bericht der Senckenbergischen Naturforschenden Gesellschaft in Frankfurt am Main [1905]: 43-55.

Kurtz F (1877) Über die Reisen des Vereinsmitgliedes Herrn J. M. Hildebrand in Ostafrika. Verhandlungen des botanischen Vereins der Provinz Brandenburg 19: iii-ix.

Laurent RF (1941) Contributionà la Systématique du genre Hyperolius Rapp. (Batraciens). Revue de Zoologie et de Botanique Africaines 34(2): 149-167. [p1. 7-9.]

Laurent RF (1943) Les Hyperolius (Batraciens) du Musée du Congo. Annales du Musée du Congo Belge, C, Zoologie, sér. 1, 4(2): 61-140.
Laurent RF (1947) Sur quelques rhacophorides nouveaux de Parc National Albert appartenant aux genres Megalixalus et Hyperolius. Bulletin du Musée Royal d'Histoire Naturelle de Belgique 23: 1-8.

Laurent RF (1958) La réserve naturelle intégrale du mont Nimba. XIII. Les rainettes du genre Hyperolius. Mémoires de l'Institut français d'Afrique Noire 53: 275-299. [pl. 1-3.]

Laurent RF (1961) Note sur les Hyperolius et quelques Afrixalus (Salientia) du Musée de Berlin. Revue de Zoologie et de Botanique Africaines 64(1-2): 65-96.

Lichtenstein H, Martens E von (1856) Nomenclator Reptilium et Amphibiorum Musei Zoologici Berolinensis. Namenverzeichnißs der in der zoologischen Sammlung der Königlichen Universität zu Berlin aufgestellten Arten von Reptilien und Amphibien nach ihren Ordnungen, Familien und Gattungen. Königliche Aademie der Wissenschaften, Berlin, 48 pp. https://www.biodiversitylibrary.org/ page/31426042

Liedtke HC, Hügli D, Dehling JM, Pupin F, Menegon M, Plumptre AJ, Kujirakwinja D, Loader SP (2014) One or two species? On the case of Hyperolius discodactylus Ahl, 1931 and H. alticola Ahl, 1931 (Anura: Hyperoliidae). Zootaxa 3768: 253-290. https://doi. org/10.11646/zootaxa.3768.3.2

Lötters S, Schick S, Scheelke K, Teege P, Kosuch J, Rotich D, Veith M (2004) Bio-sketches and partitioning of sympatric reed frogs, genus Hyperolius (Amphibia; Hyperoliidae), in two humid tropical African forest regions. Journal of Natural History 38: 1969-1997. https://doi.org/10.1080/00222930310001613584

Lötters S, Schmitz A (2004) A new species of tree frog (Amphibia; Hyperolius) from the Bakossi Mountains, south-west Cameroon. Bonner Zoologische Beiträge 52: 149-154.

Loveridge A (1936a) African reptiles and amphibians in Field Museum of Natural History. Field Museum of Natural History, Zool. Ser. 22(1): 1-111. https://www.biodiversitylibrary.org/page/2780189

Loveridge A (1936b) Scientific results of an expedition to rain forest regions in eastern Africa. VII. Amphibians. Bulletin of the Museum of Comparative Zoology 79(7): 365-430. [3 pls.]

Loveridge A (1942) Scientific results of a fourth expedition to forested areas in East \& Central Africa. Bulletin of the Museum of Comparative Zoology 91(5): 373-436. [pl. 1-4.]

Loveridge A (1953) Zoological results of a fifth expedition to East Africa. Bulletin of the Museum of Comparative Zoology 110(4): 321-406. [pl. 1-4.]

Loveridge A (1957) Check list of the reptiles and amphibians of East Africa (Uganda; Kenya; Tanganyika; Zanzibar). Bulletin of the Museum of Comparative Zoology 117(2): 151-362. [+ i-xxxvi [Index]]

Manaças S (1949) Batráquios Faneroglossus da Guiné Portuguesa. Anais da Junta de Investiçaõoes Coloniais 4: 143-164. [pl. 1.]

Mansfeld A (1908) Urwald-Dokumente. Vier Jahre unter den Crossflussnegern Kameruns. Dietrich Reimer, Berlin, 309 pp. [+ (1) pp., 32 pls., 2 maps] https://doi.org/10.5479/sil.382568.39088006245252

Marques MP, Ceríaco LMP, Blackburn DC, Bauer AM (2018) Diversity and distribution of the amphibians and terrestrial reptiles of Angola. Atlas of historical and bibliographic records (1840-2017). Proceedings of the California Academy of Sciences, Ser. 4, 65, Suppl. II: $1-501$.

Matschie P (1892) Über eine kleine Sammlung von Säugethieren und Reptilien, welche Herr L. Conradt aus Usambara (Deutsch-Ostafrika) heimgebracht hat. Sitzungsberichte der Gesellschaft für Natur- 
forschende Freunde zu Berlin [1892]: 101-110. https://www.biodiversitylibrary.org/page/8790567

Matschie P (1906) Einige noch nicht beschriebene Arten des afrikanischen Büffels. Sitzungsberichte der Gesellschaft für Naturforschende Freunde zu Berlin 7: 161-179.

Mechow A von (1882) Bericht über die von ihm geführte Expedition zur Aufklärung des Kuango-Stromes (1878/81). Verhandlungen der Gesellschaft für Erdkunde zu Berlin 9: 475-489.

Mecklenburg AF (1921) Vom Kongo zum Niger und Nil. Berichte der deutschen Zentral-Afrika-Expedition 1910/1911. F. A. Brockhaus, Leipzig, Vol. 1, x +324 pp., 4 maps, Vol. 2, x +398 pp., 2 maps [3rd Edition].

Mercurio V (2011) Amphibians of Malawi. An analysis of their richness and community diversity in a changing landscape. Edition Chimaira, Frankfurt am Main (Frankfurt Contributions to Natural History Volume 49), $393 \mathrm{pp}$.

Mertens R (1938) Herpetologische Ergebnisse einer Reise nach Kamerun. Abhandlungen der Senckenbergischen Naturforschenden Gesellschaft, Frankfurt am Main 442: 1-52.

Mertens R (1975) Richard Oeser (1891-1974) zum Gedächtnis. Salamandra 11(1): 1-6.

Meyer AB (1875 „1874“) Eine Mittheilung von Hrn. Dr. Adolf Bernhard Meyer über die von ihm auf Neu-Guinea und den Inseln Jobi, Mysore und Mafoor im Jahre 1873 gesammelten Amphibien. Monatsberichte der Königlichen Preussische Akademie der Wissenschaften zu Berlin 1874: 128-140.

Meyer H (1913) Übersichtskarte. Hans Meyer's Ostafrika-Expedition 1911. Mitteilungen aus den deutschen Schutzgebieten, Ergänzungsheft 6 .

Mildbraed J (1923) August Zenker. Notizblatt des Königlichen botanischen Gartens und Museums zu Berlin 8(74): 319-324.

Mocquard F (1905) Note préliminaire sur une collection de reptiles et de batraciens offerte au Muséum par M. Maurice de Rothschild. Bulletin du Museum National d'Histoire Naturelle, Paris 11(1): 285-290.

Neumann O (1898) Beiträge zur Vogelfauna von Ost- und Central-Afrika. Die von mir auf meiner Reise durch die Massai-Länder und in den Ländern am Victorya Nyansa 1892-1895 gesammelten und beobachteten Vögel. Journal für Ornithologie 46: 227-305. https:// doi.org/10.1007/BF02208449

Neumann O (1902a) Von der Somali-Küste durch Süd-Äthiopien zum Sudan. Zeitschrift der Gesellschaft für Erdkunde zu Berlin [1902]: 7-32. [pl. 1.]

Neumann O (1902b) From the Somali coast through southern Ethiopia to the Sudan. The Geographical Journal 20(4): 373-398. [map] https://doi.org/10.2307/1775561

Nieden F (1910a) Neue Reptilien und Amphibien aus Kamerun. Archiv für Naturgeschichte Berlin 76(1): 234-246.

Nieden F (1910b) Die Fauna der deutschen Kolonien. Reihe I: Kamerun, Heft 2. Die Reptilien (außer den Schlangen) und Amphibien. R. Friedländer \& Sohn, Berlin, 74 pp. [map.]

Nieden F (1913) Amphibia. In: Schubotz H (ed.). Wissenschaftliche Ergebnisse der Deutschen Zentral-Afrika-Expedition 1907-1908 unter Führung Adolf Friedrichs, Herzogs zu Mecklenburg. Band IV, Zoologie II. Klinkhardt \& Biermann, Leipzig, 165-195. [pl. 5.]

Nieden F (1915) Neues Verzeichnis der Kriechtiere (außer Schlangen) von Deutsch-Ostafrika. II. Teil: Amphibia. Mitteilungen aus dem Zoologischen Museum zu Berlin 7(3): 345-390.
Nkwi PN (1989) The German Presence in the Western Grassfields 1891-1913. A German colonial account. Research Report no. 37, African Studies Centre, Leiden, $121 \mathrm{pp}$.

[ÖAW] Österreichischen Akademie der Wissenschaften [Ed.] (1959) Grauer, Rudolf, Afrikaforscher. In: Das Österreichische Biographische Lexikon, Vol. 2, 50 pp.

Paepke H-J (1995) Über das Leben und Werk von Ernst Ahl. Mitteilungen aus dem Zoologischen Museum Berlin 71(1): 79-101. https:// doi.org/10.1002/mmnz.4830710110

Paepke H-J (2013) Ernst Ahl (1898-1945), sein Leben und seine Bedeutung für die Herpetologie und Terrarienkunde. Sekretär 13(1): $15-46$.

Paepke H-J, Seegers L (1995) Friedrich Fülleborns Forschungen im Njassa-Land. - Die Aquarien- und Terrarien-Zeitschrift, DATZ Sonderheft, "Malawisee“, Oktober 1995: 21-30.

Pakenham RHW (1983) The reptiles and amphibians of Zanzibar and Pemba Islands (with a note on the freshwater fishes). Journal of the East African Natural History Society and National Museum 177: $1-40$.

Perret J-L (1962) Revision des types de Leptopelis et note sur quelques Hyperolius (Amphibia Salientia) de la région camerounaise, conservés au Museum de Berlin. Revue de Zoologie et de Botanique Africaines 65(3-4): 235-246.

Perret J-L (1966) Les amphibiens du Cameroun. Zoologische Jahrbücher. Abteilung für Systematik, Ökologie und Geographie 93: 289-464.

Perret J-L (1976a) Révision des amphibiens africains et principalement des types, conservés au Musée Bocage de Lisbonne. Arquivos do Museu Bocage. Sér. 2, 6: 15-34.

Perret J-L (1976b) Identité de quelques Afrixalus (Amphibia, Salientia, Hyperoliidae). Bulletin de la Société Neuchâteloise des Sciences Naturelles 99: 19-28.

Perret J-L, Mertens R (1957) Étude d'une collection herpétologique faite au Cameroun de 1952 à 1955. Bulletin de l'Institut française d'Afrique Noire, Sér. A 19(2): 548-601.

Peters W[CH] (1854) Diagnosen neuer Batrachier, welche zusammen mit der früher (24. Juli und 18. August) gegebenen Übersicht der Schlangen und Eidechsen mitgetheilt werden. Bericht über die zur Bekanntmachung geeigneten Verhandlungen der Königlich Preußischen Akademie der Wissenschaften zu Berlin 1854: 614-628.

Peters W[CH] (1867 „1866“) Eine vorläufige Übersicht der aus dem Nachlass des Baron Carl von der Decken stammenden und auf seiner ostafrikanischen Reise gesammelten Säugethiere und Amphibien. Monatsberichte der Königlichen Preussische Akademie der Wissenschaften zu Berlin 1866: 884-892.

Peters W[CH] (1875) Über die von Hrn. Professor Dr. R. Buchholz in Westafrika gesammelten Amphibien. Monatsberichte der Königlichen Preussische Akademie der Wissenschaften zu Berlin 1875: 196-212.

Peters W[CH] (1876) Eine zweite Mittheilung über die von Hrn. Professor Dr. R. Buchholz in Westafrica gesammelten Amphibien. Monatsberichte der Königlichen Preussische Akademie der Wissenschaften zu Berlin 1876: 117-123.

Peters W[CH] (1877a) Übersicht der Amphibien aus Chinchoxo (Westafrika), welche von der Africanishchen Gesellschaft dem Berliner zoologischen Museum übergeben sind. Monatsberichte der Königlichen Preussische Akademie der Wissenschaften zu Berlin 1877: 
611-620 [reprinted 1878 in Correspondenzblatt der Africanischen Gesellschaft 2(31): 261-265].

Peters W[CH] (1877b) Nachtrag zu [,„Übersicht der Amphibien aus Chinchoxo (Westafrika), welche von der Africanischen Gesellschaft dem Berliner zoologischen Museum übergeben sind.] Monatsberichte der Königlichen Preussische Akademie der Wissenschaften zu Berlin 1877: 620-621 [reprinted 1878 in Correspondenzblatt der Africanischen Gesellschaft 2(31): 265-266].

Peters W[CH] (1878) Über die von Hrn. J. M. Hidebrandt während seiner letzten ostafrikanischen Reise gesammelten Säugethiere und Amphibien. Monatsberichte der Königlichen Preussische Akademie der Wissenschaften zu Berlin 1878: 194-209.

Peters W[CH] (1882a) Über neue Batrachier der Gattung Hyperolius und Limnodytes (Hylorana) aus Africa. Sitzungsberichte der Gesellschaft Naturforschender Freunde zu Berlin 1882: 8-10. https:// www.biodiversitylibrary.org/page/7796069

Peters W[CH] (1882b) Zoologie III. Amphibien. Naturwissenschaftliche Reise nach Mozambique auf Befehl seiner Majestät des Königs Friedrich Wilhelm IV. in den Jahren 1842 bis 1848 ausgeführt von Wilhelm C. H. Peters. G. Reimer, Berlin, 191 pp.[33 pls.]

Pfaffl F (2017) Zur Geschichte der Pommerschen Naturforschenden Gesellschaft (1818-1944) in Stettin an der Oder. Der Bayerische Wald, N.F. $30(1+2)$ : $64-68$

Pfeffer G (1889) Übersicht der von Herrn Dr. Franz Stuhlmann in Ägypten, auf Sansibar und dem gegenüberliegenden Festlande gesammelten Reptilien, Amphibien, Fische, Mollusken und Krebse. Mitteilungen aus den Naturhistorischen Museum in Hamburg, 6. Jg. [1888]: $1-36$.

Pfeffer G (1893) Ostafrikanische Reptilien und Amphibien, gesammelt von Herrn Dr. F. Stuhlmann im Jahre 1888 und 1889. Jahrbuch der Hamburgischen Wissenschaftlichen Anstalten 10: 69-105.

Pickersgill M (2007a) Frog search. Results of expeditions to southern and eastern Africa from 1993-1999. Edition Chimaira, Frankfurt am Main (Frankfurt Contributions to Natural History Volume 28), 574 pp.

Pickersgill M (2007b) A redefinition of Afrixalus fulvovittatus (Cope, 186) and Afrixalus vittiger (Peters, 1876) (Amphibia, Anura, Hyperoliidae). African Journal of Herpetology 56: 23-37. https://doi.org/1 0.1080/21564574.2007.9635551

Pollen FPL (1867) Een Blik in Madagaskar. P. W. M. Trap, Leyden, $49 \mathrm{pp}$.

Pollen FPL (1868) Recherches sur la Faune de Madagascar et de ses Dépandances, d'après les découvertes de Francois P. L. Pollen et D. C. van Dam. 1re Partie, Relation de Voyage. J. K. Steenhoff, Leiden, 240 pp. [2 maps, 9 pls.] https://www.biodiversitylibrary.org/ page/32054372

Portik DM, Bell RC, Blackburn DC, Bauer AM, Barratt CD, Branch WR, Burger M, Channing A, Colston TJ, Conradie W, Dehling JM, Drewes RC, Ernst R, Greenbaum E, Gvoždík V, Harvey J, Hillers A, Hirschfeld M, Jongsma GFM, Kielgast J, Kouete MT, Lawson LP, Leaché AD, Loader SP, Lötters S, van der Meijden A, Menegon M, Müller S, Nagy ZT, Ofori-Boateng C, Ohler A, Papenfuss TJ, Rößler D, Sinsch U, Rödel M-O, Veith M, Vindum J, Zassi-Boulou A-G, McGuire JA (2019) Sexual dichromatism drives diversification within a major radiation of African amphibians. Systematic Biology 68: 859-875. https://doi.org/10.1093/sysbio/syz023

Poynton JC, Broadley DG (1987) Amphibia Zambesiaca 3. Rhacophoridae and Hyperoliidae. Annals of the Natal Museum 28 (1): 161-229.

Rapp W von (1842) Neue Batrachier. Archiv für Naturgeschichte, Berlin 8(1): 289-291. [pl. 6.]
Reichenow A (1874) Zur Vogelfauna Westafrika's. Ergebnisse einer Reise nach Guinea. Journal für Ornithologie 22(128): 353-388. https://doi.org/10.1007/BF02004082

Reichenow A (1897) Zur Vogelfauna von Togo. Journal für Ornithologie 45(1): 1-51. https://doi.org/10.1007/BF02208294

Reichenow A (1911) Die ornithologischen Sammlungen der Zoologisch-Botanischen Kamerun-Expedition 1908 und 1909. Mit einer Übersicht aller bis jetzt aus Kamerun bekannten Vogelarten. Mitteilungen aus dem Zoologischen Museum in Berlin 5(2): 203-258. [map.] https://doi.org/10.1002/mmnz.4830050203

Rieck W (2001) Ernst Ahl (1898-1945). In: Rieck W, Hallmann G, Bischoff W (Eds) Die Geschichte der Herpetologie und Terrarienkunde im deutschsprachigen Raum. Mertensiella 12: 410-411.

Riedl-Dorn C (2001) Rudolf Grauer. In: Seipel W (Ed.) Die Entdeckung der Welt. Die Welt der Entdeckungen. Österreichische Forscher, Sammler, Abenteurer. Skira editore, Milano, 323-327.

Rödel M-O (1996) Amphibien der westafrikanischen Savanne. Edition Chimaira, Frankfurt am Main, 283 pp. [8 pls.]

Rödel M-O, Kosuch J, Grafe TU, Boistel R, Assemian NGE, Kouamé NGG, Tohé B, Gourène G, Perret J-L, Henle K, Tafforeau P, Pollet N, Veith M (2009) A new tree-frog genus and species from Ivory Coast, West Africa (Amphibia: Anura: Hyperoliidae). Zootaxa 2044: 23-45. https://doi.org/10.11646/zootaxa.2044.1.2

Rödel M-O, Kosuch J, Veith M, Ernst R (2003) First record of the genus Acanthixalus Laurent, 1944 from the Upper Guinean rain forest, West Africa, with the description of a new species. Journal of Herpetology 37(1): 43-52. https://doi.org/10.1670/0022-1511(2003)037[0043:FROTGA]2.0.CO;2

Rödel M-O, Sandberger-Loua L, Penner J, Mané Y, Hillers A (2010) The taxonomic status of Hyperolius spatzi Ahl, 1931 and Hyperolius nitidulus Peters, 1875 (Amphibia: Anura: Hyperoliidae). Bonn zoological Bulletin 57: 177-188.

Rosenberg H von (1886) In Memoriam Dr. François P. L. Pollen. Ornis - Journal of the International Ornithological Committee 2: 618-620.

Sabaj MH (2020) Codes for natural history collections in ichthyology and herpetology. Copeia 108(3): 593-669. https://doi.org/10.1643/ ASIHCODONS2020

Schabel HG (1990) Tanganyika forestry under German colonial administration, 1891-1919. Forest \& Conservation History 34(3): 130141. https://doi.org/10.1007/BF02006174

Schalow H (1886) Der ornithologische Nachlass Dr. Richard Böhm's. Journal für Ornithologie 34, 174: 409-436. https://doi.org/10.1007/ BF02006174

Schalow H (1888) Von Sansibar zum Tanganjika. Briefe aus Ostafrika von Dr. Richard Böhm. F. A. Brockhaus, Leipzig, 171 pp. [map.]

Scherz MD, Rasolonjatovo SM, Köhler J, Rancilhac L, Rakotoarison A, Raselimanana AP, Ohler A, Preick M, Hofreiter M, Glaw F, Vences, M (2020) 'Barcode fishing' for archival DNA from historical type material overcomes taxonomic hurdles, enabling the description of a new frog species. Scientific Reports 10: e19109. https://doi. org/10.1038/s41598-020-75431-9

Schick S, Kielgast J, Rödder D, Muchai V, Burger M, Lötters S (2010) New species of reed frog from the Congo basin with discussion of paraphyly in Cinnamon-belly reed frogs. Zootaxa 2501: 23-36. https://doi.org/10.11646/zootaxa.2501.1.2

Schiøtz A (1967) The treefrogs (Rhacophoridae) of West Africa. Spolia Zoologica Musei Hauniensis. København 25: 1-346.

Schiøtz A (1975) The Treefrogs of Eastern Africa. Steenstrupia, Copenhagen, $232 \mathrm{pp}$. 
Schlegel H (1837) Abbildungen neuer oder unvollständig bekannter Amphibien, nach der Natur oder dem Leben entworfen, herausgegeben und mit einem erläuternden Texte begleitet. Arnz \& Comp., Düsseldorf, 141 pp. https://www.biodiversitylibrary.org/page/49035381

Schnee H [Ed.] (1920a) Deutsches Kolonial-Lexikon, I. Band A-G. Quelle \& Meyer, Leipzig, [xxx + (1)] 776 pp.

Schnee H [Ed.] (1920b) Deutsches Kolonial-Lexikon, III. Band P-Z. Quelle \& Meyer, Leipzig, 778 pp.

Schubotz H (1909) Vorläufiger Bericht über die Reise und die zoologischen Ergebnisse der Deutschen Zentralafrika-Expedition 19071908. Sitzungsberichte der Gesellschaft naturforschender Freunde zu Berlin 7 [July]: 383-410. [map.]

Schubotz H (1912) Vorwort. In: Schubotz H (Ed.) Wissenschaftliche Ergebnisse der Deutschen Zentral-Afrika-Expedition 1907-1908 unter Führung Adolf Friedrichs, Herzogs zu Mecklenburg. Band IV, Zoologie II. Klinkhardt \& Biermann, Leipzig, vii-xiii.

Schultheß A von (1918) Neue Hymenopteren aus Madagaskar, gesammelt von Dr. K. Friedrichs [sic]. Neue Beiträge zur systematischen Insektenkunde, Beilage zur Zeitschrift für wissenschaftliche Insektenbiologie 1(13): 97-101.

Schulz-Parthu A [Ed.] (1997) Carlo von Erlanger: Wie ein Blick in die Lande eines schönen Edens. Zwei Expeditionsberichte. Leinpfad Verlag, Ingelheim, $88 \mathrm{pp}$.

Segniagbeto GH, Bowessidjaou JE, Dubois A, Ohler A (2007) Les amphibiens du Togo: état actuel des connaissances. Alytes 24(1-4): 72-90.

Sieberg H [Ed.] (1998) Zeitenumbruch in Ostafrika. Sansibar, Kenia und Uganda (1894-1913). Erinnerungen des Kaufmanns R. F. Paul Huebner. Hildesheimer Universitätsschriften, Band 3, 315 pp.

Sjöstedt Y (1910) Wissenschaftliche Ergebnisse der Schwedischen Zoologischen Expedition nach dem Kilimandjaro, dem Meru und den umgebenden Massaisteppen Deutsch-Ostafrikas 1905-1906, 1. Band, Abt. 1-7. P. Palmquist, Stockholm, 435 pp. [31 pls.] https:// www.biodiversitylibrary.org/page/1372178

Sokolowsky A (1903) Bemerkungen über einige von der $\mathrm{Ku}$ nene-Sambesi-Expedition gesammelten Kriechtiere. In: Warburg O (Ed.) Kunene-Sambesi-Expedition, H. Baum 1903. Kolonial-Wirtschaftliches Komitee, Berlin, 540-542.

Spatz P (1926) Meine Reise nach Rio de Oro. Reisebericht und Beobachtungen an Säugetieren. Zeitschrift für Säugetierkunde 1: 23-28.

Spatz P (1930) Reisen aus den Jahren 1928 und 1929 nach dem Senegal und Mauretanien. Zeitschrift für Säugetierkunde 5: 1-13.

Steindachner F (1867) Reise der österreichischen Fregatte Novara um die Erde in den Jahren 1857, 1858, 1859 unter den Befehlen des Commodore B. von Wüllerstorf-Urbair. Zologischer Theil. 1. Amphibien. Kaiserlich-Königliche Hof- und Staatsdruckerei, Wien, 70 pp. [pl. I-II.]

Steindachner F (1911) Vorläufiger Bericht über drei neue Arten aus der Familie Chamaeleontidae, welche von dem Afrikareisenden Herrn R. Grauer in den Urwäldern westlich des Tanganikasee gesammelt wurden. Anzeiger der kaiserlichen Akademie der Wissenschaften [Wien], Mathematisch-Naturwissenschaftliche Klasse 48(12): 177-179.

Sternfeld R (1913) Reptilia. In: Schubotz H (Ed.) Wissenschaftliche Ergebnisse der Deutschen Zentral-Afrika-Expedition 1907-1908 unter Führung Adolf Friedrichs, Herzogs zu Mecklenburg. Band IV, Zoologie II. Klinkhardt \& Biermann, Leipzig, 197-279. [pl. 6-9.]

Stresemann E (1943) Anton Reichenow. 1. VIII. 1847-6. VII. 1941. Journal für Ornithologie 91(1): 111-120. https://doi.org/10.1007/ BF01967662
Stresemann E (1947) Obituary. Oscar Neumann. The Ibis 89(3): 519521. https://doi.org/10.1111/j.1474-919X.1947.tb04377.x

Stuhlmann F (1891) Ein Ausflug nach Uganda. Mitteilungen von Forschungsreisenden und Gelehrten aus den deutschen Schutzgebieten 4: 213-220. [map.]

Stuhlmann F [Ed.] (1893) Zoologische Ergebnisse einer in den Jahren 1888-1890 mit Unterstützung der Kgl. Akademie der Wissenschaften zu Berlin von Dr. Franz Stuhlmann in die Küstengebiete von Ost-Afrika unternommenen Reise. I. Band: Vorwort. Dietrich Reimer, Berlin, 2 pp. [compilation of papers published in Jahrbuch der Hamburgischen Wissenschaftlichen Anstalten] https://www.biodiversitylibrary.org/page/36880504

Stuhlmann F (1894) Mit Emin Pascha ins Herz von Afrika. Dietrich Reimer, Berlin, 901 pp. [33 pls., 2 maps.]

Stuhlmann F (1909) Deutsch-Ost-Afrika. Wissenschaftliche Forschungsresultate über Land und Leute unseres ostafrikanischen Schutzgebietes und der angrenzenden Länder. Band X. Beiträge zur Kulturgeschichte von Ostafrika. Allgemeine Betrachtungen und Studien über die Einführung und wirtschftliche Bedeutung der Nutzpflanzen und Haustiere mit besonderer Berücksichtigung von Deutsch-Ostafrika. Dietrich Reimer, Berlin, 907 pp. https://www. biodiversitylibrary.org/page/37139127

Templin B [Ed.] (2015) Mein Leben [G. T. Tessmann]. Tagebuch in 12 Bänden. Teil 2, Abschnitt III. Lübecker Beiträge zur Ethnologie 3: 1-304.

Teusz S (2018) Julius Eduard Teusz (1845-1912) - Biolog, Odkrywca, Podróżnik. Afryka 48: 143-155. [In Polish]

Tornier G (1896) Reptilien und Amphibien. (Kriechthiere.). In: Möbius K (Ed.) Deutsch-Ost-Afrika. Wissenschaftliche Forschungsresultate über Land und Leute unseres ostafrikanischen Schutzgebietes und der angrenzenden Länder (Vol. III). Die Thierwelt Ost-Afrikas und der Nachbargebiete. Wirbelthiere (Part 3). Dietrich Reimer, Berlin, 164 pp. [pl. i-v.] [reprinted 1897 under the title „Die Kriechthiere Deutsch-Ost-Afrikas. Beiträge zur Systematik und Decendenzlehre“ by Dietrich Reimer, Berlin, 164 pp., 5 pls.] https://www.biodiversitylibrary.org/page/36023744

Tornier G (1900) Neue Liste der Crocodile, Schildkröten und Eidechsen Deutsch Ost-Afrikas. Zoologische Jahrbücher. Abteilung für Systematik, Geographie und Biologie der Tiere 13: 579-618.

Tornier G (1902) Herpetologisch Neues aus Deutsch-Ost-Afrika. Zoologische Jahrbücher. Abteilung für Systematik, Geographie und Biologie der Tiere 16(2): 578-590.

Tornier G (1905) Pseudophryne vivipara n. sp. ein lebendig gebärender Frosch. Sitzungsberichte der Königlich Preussischen Akademie der Wissenschaften zu Berlin 39: 855-857.

Tschudi JJ von (1838) Classification der Batrachier mit Berücksichtigung der fossilen Thiere dieser Abtheilung der Reptilien. Petitpierre, Neuchatel, 99 pp. [6 pls.] https://www.biodiversitylibrary. org/page/3879538

Urban I (1917) Geschichte des Königlichen Botanischen Museums zu Berlin-Dahlem (1815-1913) nebst Aufzählung seiner Sammlungen. Beihefte zum Botanischen Centralblatt, 1. Abteilung: Anatomie, Histologie, Morphologie und Physiologie der Pflanzen 34(1/2): 1-457.

Verdcourt B (2002) Collectors in East Africa - 31. Baron Carl Claus von der Decken - 1833-1865. The Conchologists'Newsletter 162: 204-211.

Wassmann E (1922) Die Paussiden des Zoologischen Staatsinstituts und Zoologischen Museums zu Hamburg (außer der Gattung Arthropterus), mit einem Anhange über die Endomychidengattung Trochoideus. Mitteilungen aus dem Zoologischen Staatsinstitut und Zoologischen Museum in Hamburg 34: 12-38. 
Weidmann C (1894) Deutsche Männer in Afrika - Lexicon der hervorragendsten deutschen Afrika-Forscher, Missionare etc. Bernhard Nöhring, Lübeck, (9), 192 pp.

Wenzel Geißler P, Gerets R, Kelly AH, Mangesho P (eds) (2020) Amani - Auf den Spuren einer kolonialen Forschungsstation in Tansania. Transcript, Bielefeld, 168 pp. https://doi. org/10.14361/9783839449592

Werner F (1908 ,1907“) Ergebnisse der mit Subvention aus der Erbschaft Treitl unternommenen zoologischen Forschungsreise Dr. Franz Werner's nach dem agyptischen Sudan und Nord-Uganda.
XII. Die Reptilien und Amphibien. Sitzungsberichte der Kaiserlichen Akademie der Wissenschaften, Mathematisch-Naturwissenschaftliche Classe 116: 1823-1926.

Werner F (1924) Neue oder wenig bekannte Schlangen aus dem Naturhistorischen Staatsmuseum in Wien. Sitzungsberichte der Kaiserlichen Akademie der Wissenschaften. Mathematisch-Naturwissenschaftliche Classe 133: 29-56.

Zenker [GA] (1890) Nachrichten über die Jaunde-Station. Mitteilungen von Forschungsreisenden und Gelehrten aus den deutschen Schutzgebieten 3: e197.

\section{Unpublished sources}

Documents kept in the Department of Historical Research (Historische Arbeitsstelle) of the Museum für Naturkunde Berlin and consulted ZMB register (accession catalogues):

Lichtenstein, H. M. Eingangsjournal über den Zugang von Naturalien des Königlichen Zoologischen Museums zu Berlin von 1816 bis 1857 (2 vols.).

Zoologisches Museum, Signature S II, "Barboza du Bocage".

Zoologisches Museum, Signature S II, "Brühl, Ludwig”.

Zoologisches Museum, Signature S III, "Fülleborn, F.".

Zoologisches Museum, Signature S III, "Küttner, Otto, Dr.”.

Zoologisches Museum, Signature S II "Museum Hamburg".

Zoologisches Museum, Signature S II "Martienssen, G.”.

Zoologisches Museum, Signature S II, "Mechow, v. - Major".

Zoologisches Museum, Signature S III, "Rolle, H.".

Zoologisches Museum, Signature S II "Stuhlmann, F.".

Zoologisches Museum, Signature S I "Temminck, C. J." (incl. correspondence of H. Schlegel and H. Boie to H. Lichtenstein).

Zoologisches Museum, Signature S II, “Thomas, Fe.”. 